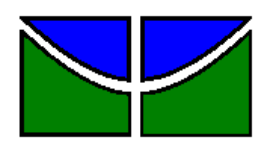

Universidade de Brasília

Faculdade de Economia, Administração, Contabilidade e Gestão de Políticas Públicas

Programa de Pós-Graduação em Economia

Mestrado Profissional em Economia

MAX DA COSTA OLIVEIRA

\title{
EFICIÊNCIA DO CALENDÁRIO DE COMPRAS PARA OS PROCESSOS DE LICITAÇÃO: estudo de caso da Universidade de Brasília.
}

Brasília - DF 


\section{Max da Costa Oliveira}

\section{EFICIÊNCIA DO CALENDÁRIO DE COMPRAS PARA OS PROCESSOS DE LICITAÇÃO: estudo de caso da Universidade de Brasília.}

Dissertação apresentada ao Curso de Mestrado Profissional em Economia, área de concentração em Gestão Econômica de Finanças Públicas, do Departamento de Economia da Faculdade de Economia, Administração, Contabilidade e Gestão de Políticas Públicas da Universidade de Brasília, como requisito parcial para obtenção do título de Mestre.

Orientador: Prof. Dr. Alexandre Maduro Abreu.

Brasília - DF 


\section{EFICIÊNCIA DO CALENDÁRIO DE COMPRAS PARA OS PROCESSOS DE LICITAÇÃO: estudo de caso da Universidade de Brasília.}

Dissertação apresentada ao Curso de Mestrado Profissional em Economia, área de concentração em Gestão Econômica de Finanças Públicas, do Departamento de Economia da Faculdade de Economia, Administração, Contabilidade e Gestão de Políticas Públicas da Universidade de Brasília, como requisito parcial para obtenção do título de Mestre.

Aprovado em 14 / 08 / 2015.

BANCA EXAMINADORA

Prof. Dr. Alexandre Maduro Abreu- Orientador

Departamento de Administração - UnB

Prof. Dr. Antônio Nascimento Júnior - Membro Externo

Departamento de Administração - UnB

Prof. Dr. Roberto de Góes Ellery Júnior - Membro

Departamento de Economia - UnB 
Dedico este trabalho aos meus pais João Fernandes e Maria Cecília, por terem me dado a oportunidades de tê-los como pais; a minha esposa Suely e aos meus filhos, Sabrina e Leandro, por todo o incentivo, paciência e ajuda que me proporcionaram para atingir o objetivo almejado; ao meu irmão Cid Costa (in memorian), precursor da família no ingresso ao ensino superior e a todos os meus familiares que de alguma forma me ajudaram e acreditaram que a realização do trabalho fosse possível. 


\section{AGRADECIMENTOS}

Agradeço a Deus, razão de toda a existência neste mundo terrestre, sem o qual nada seria possível; a minha esposa Suely e aos meus filhos, Sabrina e Leandro, por todo o apoio e paciência que tiveram comigo, nos momentos de minha ausência do lar ao longo do curso; aos meus professores do curso pelos conhecimentos transmitidos; ao professor Yury Maluf pela colaboração na formatação dos gráficos estatísticos; aos meus colegas de turma pelo companheirismo demonstrado durante o curso e ao meu orientador, Professor Doutor Alexandre Maduro Abreu, por ter dedicado momentos de sua vida para me orientar no presente trabalho. 
"O sucesso nasce do querer, da determinação $e$ persistência em se chegar a um objetivo. Mesmo não atingindo o alvo, quem busca e vence obstáculos, no mínimo fará coisas admiráveis."

(José de Alencar). 


\section{RESUMO}

Na Administração Pública, o planejamento de compras é de suma importância, sobretudo, considerando que a crescente preocupação com a questão logística das compras no Setor Público, exige que os gestores planejem suas atividades com a finalidade de satisfazer os seus clientes, com o mínimo possível de recursos. Nesse sentido, a Universidade de Brasília - UnB tornando-se multicampi agigantou-se e no decorrer dos anos, sua estrutura de compras já não suportava mais o atendimento das suas demandas por aquisição de bens e serviços comuns, principalmente, no que diz respeito à celeridade, eficiência e eficácia dos processos. Foi preciso rever com urgência os seus procedimentos de compras, os quais eram utilizados desde a década de 1980. Assim, com o intuito de proporcionar agilidade e celeridade aos processos de compras na UnB, o Decanato de Administração e Finanças (DAF) implantou em 2012, como forma de Planejamento, um Calendário de Compras, adotando como método de compra, o Pregão eletrônico na forma de Sistema de Registro de Preços. Argumentou à época, que este procedimento evitaria o fracionamento de despesas, reduziria o volume de compra por dispensa de licitação e permitiria melhor eficiência e celeridade aos processos licitatórios. Como objetivos complementares, ressaltou a redução de custos e o volume de procedimentos de compras. O presente trabalho teve por objetivo geral, avaliar a eficiência do Calendário de Compras adotado na UnB, como ferramenta de planejamento, utilizando o Pregão no formato eletrônico. Para tanto, caracterizou-se a pesquisa como descritiva e quanto aos meios, estudo de caso com uma abordagem quantitativa. Em relação ao manuseio dos dados, optou-se pela utilização do software Statistical Package for the Social Sciences (SPSS). No tocante a análise dos dados, utilizou-se a medida das correlações não paramétricas de postos de Spearman. $\mathrm{O}$ estudo concluiu que houve elevação dos custos de transação, decorrente de ações oportunistas por parte dos agentes econômicos envolvidos nos processos licitatórios analisados. Pelo resultado do teste estatístico, concluiu-se que não houve diferença entre médias, nas correlações apresentadas pelas variáveis $\mathrm{n}^{\mathbf{0}}$ de licitantes no certame $\mathrm{x}$ valor total homologado em 2011 e 2012. Foi possível concluir também, que não há evidências para crer que houve evolução nos procedimentos de compras, antes e após a implantação do atual planejamento de compras. Assim, a pesquisa concluiu que a nova sistemática de compras mostrou-se fragilizada e ineficiente, contrariando suas expectativas iniciais, que eram de tornar mais célere e eficiente o procedimento licitatório no âmbito da UnB, com a consequente redução de preços e a diminuição do volume de compras.

Palavras-chave: Administração Pública. Eficiência. Pregão Eletrônico. 


\begin{abstract}
In Public Administration, the purchasing planning is of the utmost importance, especially considering that the growing concern over the purchases' logistics issue on the Public Sector requires managers to plan their activities in order to satisfy their customers, with minimal resources. In this sense, the University of Brasilia - UNB, becoming a multi-campus institution, has grown, and over the years, its purchasing structure could no longer support the meeting to its demands for common goods and services, regarding especially to requirements such as processes' celerity, efficiency and effectiveness. There was an urgent need to review its purchase procedures, which were used since the 1980s. Thus, in order to provide agility and celerity to the purchase process at UNB, the Deanship of Administration and Finance (DAF) implemented in 2012, as a way of planning, a Purchase Calendar, adopting the Electronic Auction system as purchase method. It was argued at the time that this procedure would avoid expenses' fractionation, reduce the purchase volume through bidding exemption and allow better efficiency and celerity to the bidding process. As complementary objectives, it was stressed out the cost savings and the volume of purchase procedures. This study had the overall goal of evaluating the Purchase Calendar efficiency adopted at UNB, as a planning tool, using the Electronic Bidding system. To this end, the research was characterized as descriptive and as to its means, it was a case study with a quantitative approach. Regarding data handling, the software Statistical Package for Social Sciences (SPSS) was used. To analyze data, we used the measure of nonparametric Spearman's rank correlations. The study concluded that there was an increase on transaction costs, due to opportunistic actions on the part of economic agents involved in the analyzed bidding processes. Considering the statistical test results, it was concluded that there was no difference between means in the correlations presented by the variables number of bidders vs. total amount approved in 2011 and 2012. It was also possible to conclude that there is no evidence to believe that there was an evolution at the purchase procedures, before and after the current purchases planning implementation. Thus, the research concluded that the new purchase system proved itself fragile and inefficient, opposing itself to the initial expectations, which were to make the bidding processes within UNB faster and more efficient, with the consequent price reduction and purchase volume decrease.
\end{abstract}

Keywords: Public Administration. Efficiency. Electronic Auction. 


\section{LISTA DE FIGURAS}

Figura 1 - Pontos norteadores da Gestão Pública Atual ............................................................34

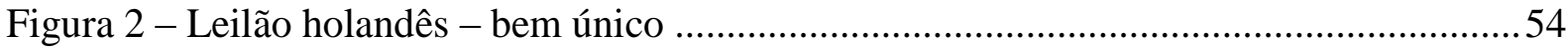

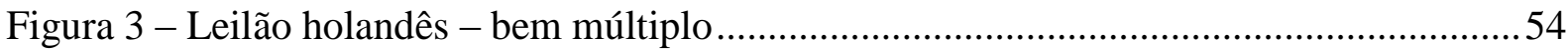

Figura 4 - Passos de um processo de licitação ............................................................................ 66

Figura 5 - Fluxograma do trâmite processual para Licitação ................................................ 89

Figura 6 - Fluxograma do trâmite processual para Dispensa de Licitação. ..............................90

Figura 7 - Fluxograma resumido do trâmite processual para compras internacionais ............ 90 


\section{LISTA DE GRÁFICOS}

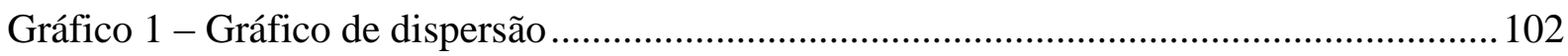

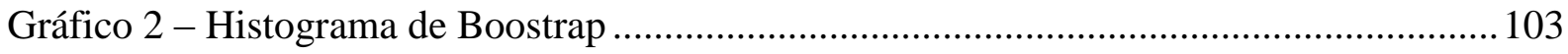




\section{LISTA DE QUADROS}

Quadro 1 - Demonstrativo de diferenças entre o processo de compras públicas e privadas ...47

Quadro 2 - Principais diferenças entre o Pregão Presencial e o Pregão Eletrônico.................. 71

Quadro 3 - Unidades de Compra e Grupos de materiais. .................................................... 91 


\section{LISTA DE SÍMBOLOS}

$\begin{array}{ll}\S & \text { Parágrafo } \\ \% & \text { Porcentagem } \\ \forall i & \text { Quantificação universal (para todos; para qualquer; para cada) } \\ \mathrm{R} \$ & \text { Reais } \\ \rho & \text { Letra grega rho }\end{array}$




\section{LISTA DE TABELAS}

Tabela 1 - Coeficiente de correlação de postos de Spearman's ............................................. 95

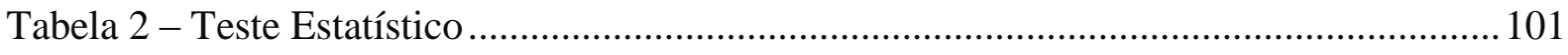

Tabela 3 - Ranks das Média dos Grupos dos Pregões de 2011 - 2012 ................................. 101 


\section{LISTA DE ABREVIATURAS E SIGLAS}

ANATEL Agência Nacional de Telecomunicações

Art. Artigo

BCE Biblioteca Central

CAIP Coordenação de Análise e Instrução Processual

CCO Coordenação de Compras

CEO Coordenação de Execução Orçamentária

CIE Coordenação de Importação e Exportação

COL Comissão de Licitação

COMPRASNET Sistema Eletrônico de Gestão de Compras

D.

Dom

DAF Decanato de Administração e Finanças

DCF Diretoria de Contabilidade e Finanças

DCO Diretoria de Compras

DEA Análise Envoltória de Dados

DGM Diretoria de Gestão de Materiais

DI

Registro de Declaração de Importação

DMU Unidade Tomadora de Decisão

DOU Diário Oficial da União

DPO Decanato de Planejamento e Orçamento

Dr. Doutor

DVD Digital Versatile Disc (Disco Digital Versátil)

EAD Educação à distância

EC Emenda Constitucional

EPI Equipamento de Proteção Individual

EPP Empresa de Pequeno Porte 
etc.

Etcetera

HD

Hard disk

ME

Microempresa

MPU

Ministério Público da União

$\mathrm{NCM}$

Normas de Classificação de Mercadorias

$\mathrm{NE}$

Nota de Empenho

$n^{\circ}$

Número

$n^{\circ} \mathrm{s}$.

Números

ONGs

Organizações não Governamentais

p.

Página

PAS

Programa de Avaliação Seriada

PJU

Procuradoria Jurídica

Prof.

Professor

PTF

Produtividade Total de Fatores

SIASG

Sistema Integrado de Administração de Serviços

SICAF

Sistema de Cadastro de Fornecedores

SIMAR

Sistema de Material

SISCOMEX Sistema Integrado de Comércio Exterior

SRP

Sistema de Registro de Preços

SPSS

Statistical Package for the Social Sciences

TCU

Tribunal de Contas da União

TI

Tecnologia de Informática

TIC

Tecnologia da Informação e Comunicação

TIC's

Tecnologias de Informações e Comunicações

UnB

Universidade de Brasília

$\mathrm{C} 2 \mathrm{C}$

Consumers to consumers

$\mathrm{B} 2 \mathrm{C}$

Buseness to consumers 


\section{SUMÁRIO}

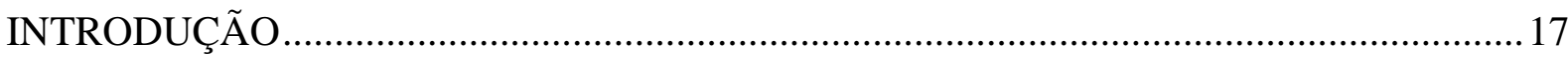

2. ADMINISTRAÇÃO PÚBLICA E GESTÃO PÚBLICA ................................................. 20

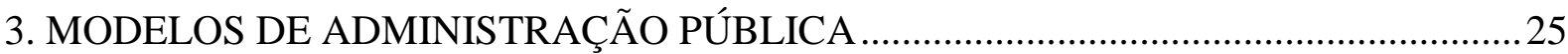

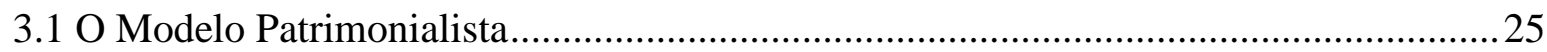

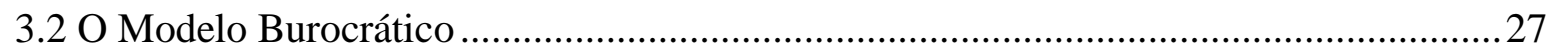

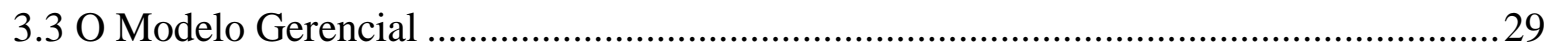

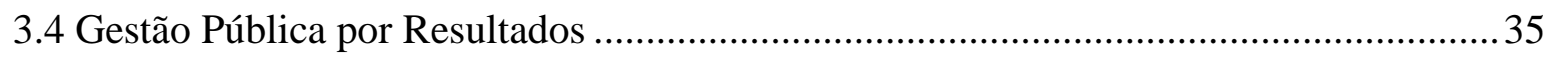

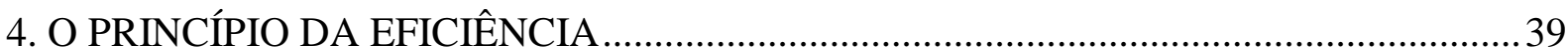

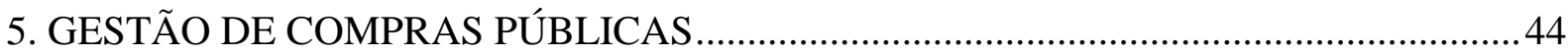

5.1 Breve histórico sobre licitações públicas no Brasil ................................................ 44

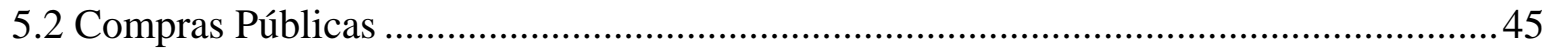

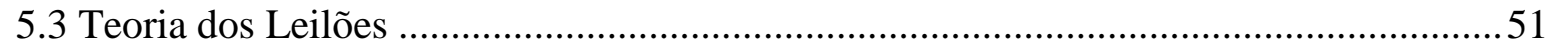

5.4 Custos de Transação sob a ótica da Nova Economia Institucional ................................55

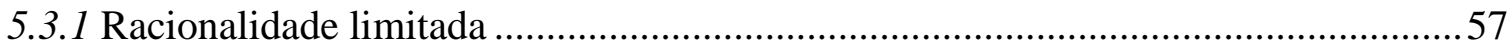

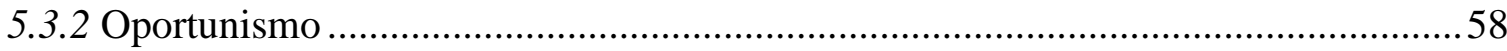

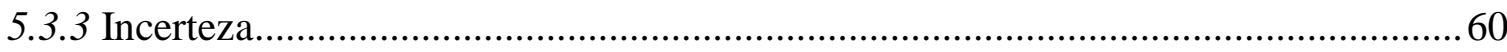

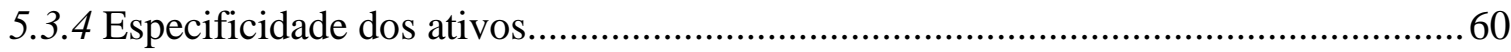

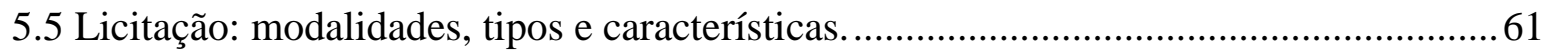

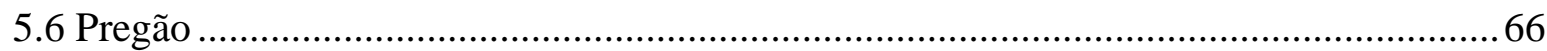

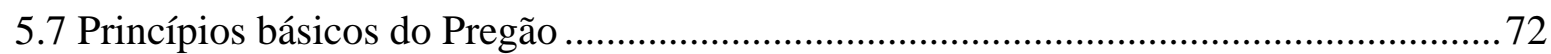

5.8 Pregão e o Sistema de Registro de Preços ................................................................ 75

5.9 O Sistema de Registro de Preços e a figura do "carona".................................................. 77

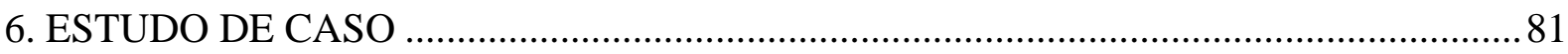

6.1 Planejamento de Compras na Universidade de Brasília ............................................ 81

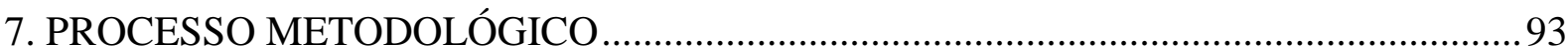




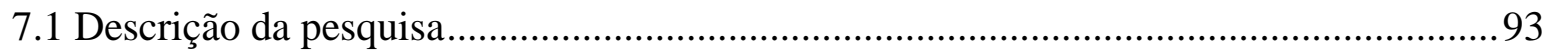

7.2 Estratégia para Análise dos Dados Quantitativos ......................................................93

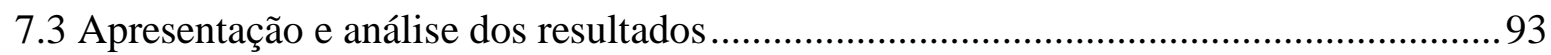

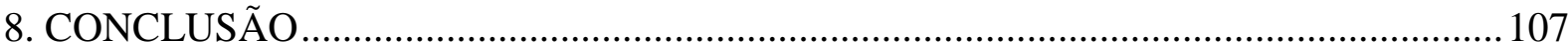

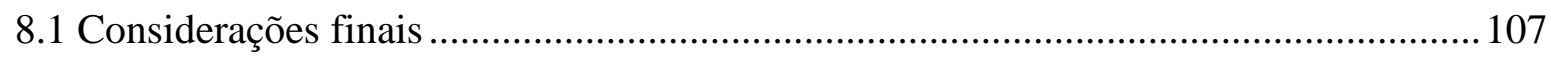

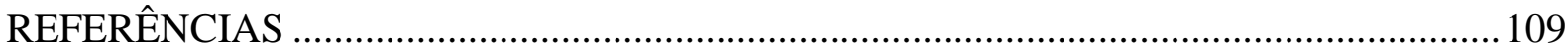

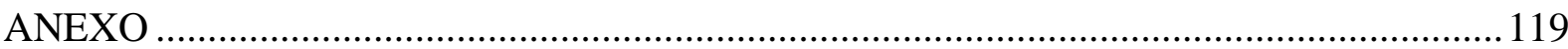




\section{INTRODUÇÃO}

Com a adesão ao Plano de Reestruturação e Expansão das Universidades Federais (REUNI); a implantação e estruturação de dois novos Campi e o redimensionamento dos Campi existentes na Universidade de Brasília (UnB) verificou-se um grande aumento na demanda por aquisição de bens e serviços comuns, ocasionando um grande gargalo no setor de compras da UnB. A demanda supracitada, em sua maioria, foi por aquisição de materiais e serviços comuns, destinados ao redimensionamento dos Campi existentes (Darcy Ribeiro e Planaltina); a estruturação dos novos Campi (Ceilândia e Gama) e as demandas de rotina dos diversos centros de custos da UnB.

Dessa forma, foi preciso rever com urgência, os procedimentos de compras utilizados pela UnB desde a década de 1980, com o fito de propiciar solução de continuidade aos processos licitatórios com agilidade e celeridade. Assim, o Decanato de Administração e Finanças (DAF) estabeleceu em 2012, um planejamento de compras, adotando como ferramenta de planejamento, um calendário de compras, com aplicação por semestre. Argumentou à época, que com esta medida, evitaria o fracionamento de despesas; reduziria o volume de compras por dispensa de licitação; permitiria melhor eficiência e celeridade aos processos; possibilitaria a redução do preço e melhora da qualidade das compras; bem como reduziria o prazo entre o pedido de compra e o seu recebimento.

Com o estabelecimento do atual planejamento de compras, utilizou-se como método de compra, a modalidade de licitação Pregão em sua forma eletrônica, preferencialmente, com o uso do Sistema de Registro de Preços (SRP). Salienta-se que esta modalidade de licitação tem sido a mais utilizada no âmbito da Administração Federal para aquisição de bens e serviços comuns.

Entretanto, ressalta-se que o alardeado sucesso das contratações com esta nova modalidade de licitação, tem sido mais econômico ao se realizar comparações simples entre o valor estimado, pesquisado informalmente antes da realização do certame e o efetivamente contratado, tornando-as mais eficazes ou não. Todavia, convém esclarecer que as pesquisas de preços iniciais, anteriores à licitação, são realizadas apenas para cumprir dispositivo legal previsto em Lei e para reservar o recurso que será dispendido posteriormente, e que desta forma, podem estar enviesadas e conduzir a interpretações equivocadas de seus resultados.

Não parece haver dúvida de que é o mercado o principal agente formador de preços, por isso, contar com a Administração para sua definição é lidar com grande risco. O exercício 
de consulta do poder público ao mercado para aferir preços é tarefa penosa e ineficiente. $\mathrm{E}$ claro, ao revelar os preços que admite como razoáveis para suas aquisições, a Administração pode, em verdade, estar inflacionando tais preços e nivelando-os acima do que os fornecedores estariam naturalmente dispostos a pagar.

Com a implantação do calendário de compras mencionado em linhas passadas, o DAF procurou sanar os problemas inerentes aos procedimentos de compras para bens e serviços comuns da UnB. Contudo, não se vislumbra na atualidade, as vantagens que o uso do Calendário de Compras está proporcionando aos processos licitatórios da Instituição. Destarte, a relevância do trabalho justifica-se pela importância que a Instituição deve proporcionar ao manejo dos seus recursos públicos, no que se refere ao atendimento das suas demandas por aquisição de bens e serviços comuns, com o máximo de economia, rapidez e lisura. Assim, buscam-se evidências que possam aclarar o seguinte questionamento: Qual o impacto do Calendário de Compras na finalização dos processos de licitação da UnB?

Considerando o panorama apresentado, o estudo em questão tem como objetivo geral, avaliar a eficiência do planejamento de compras da UnB, com o uso do Calendário de Compras como ferramenta de planejamento, utilizando o Pregão no formato eletrônico.

Para atender esta questão, pretendeu-se em primeiro plano, efetuar o levantamento de dados dos pregões realizados pela UnB, homologados nos exercícios de 2011 a 2012, extraídos do portal de compras eletrônicas - COMPRASNET do Governo Federal e da base de dados da Diretoria de Compras da UnB. Em seguida, elaboraram-se planilhas eletrônicas com os dados coletados, utilizando o aplicativo Excel. Posteriormente, proceder ao manuseio dos dados obtidos, utilizando-se o software Statistical Package for the Social Sciences (SPSS) e logo após, efetuou-se a análise dos dados utilizando a medida das correlações não paramétricas de postos de Spearman.

O trabalho em questão está estruturado em três eixos centrais: introdução, fundamentação teórica e conclusão. A primeira parte introdutória apresenta uma breve exposição sobre o tema, e um sucinto comentário inerente à implantação do atual Planejamento de Compras da UnB. Por oportuno, o estudo levanta questionamentos quanto à eficiência e eficácia do Planejamento de Compras em função do Calendário de Compras da UnB.

A segunda parte, fundamentação teórica, diz respeito aos capítulos 2 a 5 os quais contemplam temas sobre Administração Pública e Gestão Pública. Em seguida, faz uma abordagem sobre os modelos de Administração Pública e uma breve exposição sobre o tópico 
Gestão Pública por resultados. Na sequência, é dedicado um capítulo sobre o Princípio da Eficiência. Logo a seguir, apresenta o capítulo sobre a Gestão de Compras Públicas no qual são introduzidos tópicos inerentes à licitação pública no Brasil e suas principais modalidades. Posteriormente, os capítulos 6 e 7 descrevem o Planejamento de Compras da UnB e a metodologia adotada no desenvolvimento do trabalho em tela.

A terceira e última parte do trabalho, conclusão, associa-se às considerações finais. Nela, é retomado o objetivo proposto na introdução, com a apresentação resumida dos resultados obtidos e em seguida, apresentada as conclusões finais. 


\title{
2. ADMINISTRAÇÃO PÚBLICA E GESTÃo PÚBLICA
}

Com a finalidade de esclarecer as particularidades dos termos utilizados, é imprescindível que se busque alguns conceitos inerentes ao estudo da Administração Pública. A expressão "Administração Pública", iniciada com letras maiúsculas, representa o Estado atuando na condição de administrador ou na sua função administrativa. A Administração Pública também pode se referir às três funções do Estado.

Originalmente, Administração Pública é a reunião de órgãos instituídos para atingir os objetivos do Governo, e, materialmente, é o grupo dos conhecimentos técnicos essenciais à prestação dos serviços públicos. Por outro lado, o Governo, é a expressão política de iniciativa de manutenção de objetivos do Estado e de manutenção da ordem jurídica existente.

Meirelles (1989, p. 78-79) refere-se à administração pública (com iniciais minúsculas) da seguinte forma:

\begin{abstract}
Em sentido lato, administrar é gerir interesses, conforme a lei, a moral e a finalidade dos bens entregues à guarda e conservação alheia. Se os bens e interesses geridos são individuais, realiza-se administração particular; se forem da coletividade realizase administração pública. Administração Pública, portanto, é a gestão de bens e interesses qualificados da comunidade no âmbito federal, estadual ou municipal, segundo os preceitos do Direito e da Moral, visando ao bem comum.
\end{abstract}

Quanto ao sentido formal, Meirelles (1989, p. 59) assevera que a administração pública "é o conjunto de órgãos instituídos para se atingir os objetivos do Governo"; já no sentido material, "é o conjunto das funções necessárias aos serviços públicos em geral”; ao passo que na acepção operacional, “é o desempenho perene e sistemático, legal e técnico, dos serviços próprios do Estado ou por ele assumidos em benefício da coletividade".

Organizando os sentidos da expressão "Administração Pública”, entende-se que esta pode ser conceituada objetivamente como a atividade concreta e imediata que o Estado desenvolve para a consecução dos interesses coletivos e subjetivamente como o conjunto de órgãos e de pessoas jurídicas as quais a lei atribui o exercício da função administrativa do Estado (MORAES, 2002).

O conceito de "administração" é definido por Bachtold (2008, p. 26) da seguinte forma:

A palavra administração vem do latim ad (direção) e minister (obediência), ou seja, o administrador dirige obedecendo à vontade de quem o contratou. Assim, o administrador público vai conduzir seu trabalho procurando atender à necessidade da população que o elegeu (obediência ao seu objetivo). 
É possível averiguar no conceito de administração, ainda que de forma implícita, o amplo objetivo que a empresa pretende atingir: a maximização da riqueza. Já o objetivo principal da Administração Pública, em última análise, é atender ao bem comum.

No Brasil, a Administração Pública divide-se nas esferas Federal, Estadual e Municipal em Administração Pública Direta e Indireta, conforme Decreto-Lei n. 200/67. De acordo com Bacellar Filho (2005, p. 19), a Administração Pública Direta é encarregada pelo exercício de atividades típicas de Estado e constitui-se de: a) no plano federal, pelos órgãos de serviço integrados à Presidência da República e aos Ministérios; b) no plano estadual, pelo Governo do Estado e pelas Secretarias Estaduais; e c) no plano municipal, pela Prefeitura e pelas Secretarias Municipais. Já a Administração Pública Indireta, seria composta pelas autarquias, sociedades de economia mista e empresas públicas. Além dessas entidades, também compõe a Administração Pública indireta as fundações, conforme Decreto-Lei $\mathrm{n}^{\circ}$ 200/67 e Lei $n^{\circ} 7.596 / 87$.

A expressão "órgão público" também merece melhor discernimento: órgãos públicos "são instrumentos ou meios de ação pelos quais se coloca em condições de querer, de atuar e de relacionar-se com outros sujeitos de direito", o qual se caracteriza como "um centro de competências delimitado por normas legais". (SILVA, 2001, p. 661)

Mello (2005, p. 128) define órgãos públicos como "unidades abstratas que sintetizam os vários círculos de atribuições do Estado". A Lei n. 9.784/99, que regula o Processo Administrativo, define órgão como sendo "a unidade de atuação integrante da estrutura da Administração direta e da estrutura da Administração indireta".

Do mesmo modo, outra expressão a ser pormenorizada é o "agente público". Agentes Públicos são todas as pessoas físicas, designadas, definitiva ou transitoriamente, para o exercício de alguma função estatal. Comumente, desenvolvem funções do órgão, distribuídas entre os cargos de que são titulares, mas excepcionalmente podem exercer funções sem cargo.

Posteriormente à apresentação de alguns termos utilizados na Administração Pública, o comentário a seguir resume a relação existente entre os sujeitos ativos e o objeto administrativo por meio deles manifestado:

[...] o Estado é estruturado em órgãos, compostos por cargos que são titularizados pelos agentes públicos. E a pessoa jurídica estatal atua exatamente por meios desses agentes. São eles que constituem os nervos e veias que fazem com que a criação humana, que é a pessoa de direito, aja, adote comportamentos e seja responsabilizada nos limites da lei; enfim, é o agente público que dá vida à pessoa jurídica pública. (ROCHA, 1999, p. 57). 
Muito se tem dito sobre gestão pública. Trata-se de um tema de vital importância ao administrador público, o qual tem por objetivo, com absoluta compreensão, o campo de sua atuação, mostrando-lhe o caminho certo no trato da coisa pública.

Desta forma, definir o que é Gestão Pública nem sempre constitui tarefa simples, embora, saibamos em geral, quando estamos diante de atos típicos de uma Gestão Pública, e quando não o estamos. Assim, gerir é algo mais do que administrar, implicando mudanças de paradigmas conceituais, teóricos e pragmáticos.

Santos, (2006) refere-se à gestão pública como sendo as "funções de gerência pública dos negócios do governo". Assim, de acordo com Silva Oliveira (2007) pode-se classificar, de maneira resumida, o agir do administrador público em três níveis distintos:

a) atos de governo, que se situam na órbita política;

b) atos de administração, atividade neutra, vinculada à lei;

c) atos de gestão, que compreendem os seguintes parâmetros básicos:

I. tradução da missão;

II. realização de planejamento e controle;

III. administração de R. H., materiais, tecnológicos, financeiros e compras;

IV. inserção de cada unidade organizacional no foco da organização; e

V. tomada de decisão diante de conflitos internos e externos.

Portanto, fica nítida a importância da gestão pública na realização do interesse público porque é ela que vai possibilitar o controle da eficiência do Estado na realização do bem comum estabelecido politicamente e dentro das normas administrativas.

Infelizmente, nos dias atuais é grande o número de agentes políticos que desconhece totalmente a importância da função pública que está à sua disposição, acarretando com isto, gastos públicos inadequados ou equivocados, prestação de serviços públicos ineficientes e, sobretudo, prejuízo financeiro e moral para a sociedade.

Nesse sentido, o gestor público não precisa temer a gestão pública por receio de perda de poder político, mas ao contrário, deve conhecê-la e utilizá-la como forma inteligente de aumento de seu prestígio político porque somente através dela será possível dirigir política e administrativamente uma pessoa ou organização estatal com objetividade, racionalidade e eficiência (SILVA OLIVEIRA, 2007).

A gestão pública, portanto, levando-se em consideração o princípio econômico da escassez, em que as demandas sociais são constantes e os recursos financeiros para satisfazêlas são escassos, deve optar por uma administração apropriada, eficaz e eficiente de tudo aquilo que for originado no meio social, sempre tendo em vista a necessidade do coletivo. 
O princípio econômico da escassez e os recursos financeiros limitados, adicionados ao conceito de gestão pública, são importantes no entendimento do que vem a ser o moderno inserido nessa análise. Para tanto, usam-se os entendimentos de alguns autores como Bueno e Oliveira (2002), que conceituam ser a modernização da administração carregada de objetivos a serem cumpridos, como: combater o patrimonialismo e o clientelismo vigentes durante tantos anos; melhorar a qualidade da sua prestação de serviços à sociedade; aprimorar o controle social; fazer mais ao menor custo possível, aumentando substancialmente a sua eficiência, pois não há recursos infinitos disponíveis para o alcance de todas as demandas sociais, conforme conceituam.

Neste sentido, Garde apud Marques (2008, p. 221), conceitua que:

\begin{abstract}
A nova Gestão Pública trata de renovar e inovar o funcionamento da Administração, incorporando técnicas do setor privado, adaptadas às suas características próprias, assim como desenvolver novas iniciativas para o logro da eficiência econômica e a eficácia social. Subjaz nela a filosofia de que a administração pública oferece oportunidades singulares, para melhorar as condições econômicas e sociais dos povos.
\end{abstract}

Essa nova gestão norteia-se na informação, cuja essência assume o caráter do conteúdo da ação de ter que ser disseminada, depois de analisada e armazenada, bem como ser liberada, para que possa ser utilizada em futuras tomadas de decisão, novo controle e posterior avaliação.

Desta forma, resume-se que a gestão pública moderna tem como princípio um conteúdo ético, moral e legal por parte daqueles que dela participam, tendo como objetivo a crença no resultado positivo da política pública a ser executada e na credibilidade na administração pública exercida pelos mesmos. Com tal característica, é um componente dela a existência de um conteúdo pleno de elementos tecnológicos que facilitem a utilização destes para administrar com potencial de eficácia e eficiência que se espera da Administração dos bens públicos.

Não obstante aos relatos mencionados em linhas passadas, ressalta-se ainda, que uma das questões mais importantes para o administrador público é a da relação que ele, como servidor investido do poder do Estado, irá instituir com o setor privado no decorrer do exercício da sua função. Dependendo da área de intervenção do Estado, essa relação será mais ou menos frequente, porém, será sempre delicada e sensível, pois está balizada por uma série de mediações processuais rigidamente estabelecidas pela lei.

O conjunto de regras que rege as relações do poder público com o setor privado, não foi criado pelo legislador para prejudicar a ação do administrador público, mas, sim, para 
garantir a excelência do interesse público nas relações que o Estado institui com os agentes privados e que são custeadas com o dinheiro do contribuinte.

Nesse contexto, os princípios norteadores e nucleares da administração pública estão consolidados em doze regras de observância permanente e obrigatória para o bom administrador. Conforme consolidado na Carta Magna de 1988 e elencado no art. 37, é possível vislumbrar: legalidade, moralidade, impessoalidade, publicidade, eficiência. Contudo, de maneira implícita, é possível detectar outros princípios como: razoabilidade, proporcionalidade, ampla defesa, contraditório, segurança jurídica, motivação e supremacia do interesse público.

Como bem observado, esses princípios deverão ser assegurados em todos os atos e atividades administrativas de todo aquele que exerce o poder público. Desta forma, constituem, por mera expressão simbólica, os fundamentos da ação administrativa. 


\section{MODELOS DE ADMINISTRAÇÃO PÚBLICA}

O capítulo em questão aborda de forma sucinta, a evolução dos modelos de gestão na Administração Pública ao longo dos séculos, desde o modelo patrimonialista até o modelo gerencial, tão exaltado nos dias atuais.

O modelo usual que foi adotado no Brasil por D. João VI no início do século XIX com o advento do Governo Imperial, era o tipo de administração que definia as monarquias absolutas, em que o patrimônio público e o patrimônio privado eram confundidos. A burocracia patrimonialista era permeada por nepotismo e clientelismo, necessitando de independência política, apesar de já existirem em tais estados uma Constituição, um sistema jurídico, um serviço público e um governo.

Com o crescimento do capitalismo, o patrimonialismo foi substituído por um tipo de administração que contemplava tal distinção: a burocracia. Como modelo organizacional estudado principalmente por Max Weber, a ascensão da burocracia implicava no advento de instituições fortes, baseadas na centralização, na disciplina normativa e no caráter impessoal de seus membros.

O modelo burocrático surgiu com a deficiência do modelo anterior e respondeu com elevada eficácia às demandas administrativas, tendo sido implantado nos anos de 1930 no Brasil. Após este período, com a complexidade que as administrações públicas passaram a ter, as mesmas precisaram demandar uma grande quantidade e diversidade de tarefas, sobretudo para o funcionamento do Estado de Bem-Estar Social (Welfare State), o que levou ao enfraquecimento dos clássicos mecanismos da burocracia.

Nos anos de 1970 e 1980, a tendência neoliberal passou a dar ênfase à fragilidade econômica gerada por tal estado, indicando a solução de mercado e do Estado mínimo para a redução da estrutura administrativa. O crescimento da ideia de que o modelo burocrático era ineficiente para garantir o novo padrão funcional de um estado eficiente leva à ascensão do novo modelo administrativo, denominado gerencial ou pós-burocrático.

\subsection{O Modelo Patrimonialista}

A administração pública patrimonialista é típica dos Estados absolutistas europeus do século XVIII, onde o Estado era a extensão do poder do administrador público e os seus servidores eram vistos como nobres que recebiam este título por indicações do governante. Essas indicações eram feitas como prova de gratidão e também como estratégia para defesa de 
seus interesses. Como consequência desse pensamento, a corrupção e o nepotismo são inerentes a esse tipo de administração.

Tal fenômeno (considerado como pernicioso para a economia e o desenvolvimento das modernas sociedades), entretanto, se mostra ainda bastante firme, e dependendo do desenvolvimento de cada país, estado ou município, sua intensidade é maior ou menor.

Segundo Webber apud Gomes e Oliveira (2010), o conceito de patrimonialismo resulta da introdução de uma variante da dominação tradicional baseada na "crença na santidade de ordens e poderes senhoriais tradicionais".

De acordo com Froes e Melo Neto (2006), a Administração Pública Patrimonialista caracterizava-se pela incapacidade ou resistência do administrador em separar o patrimônio público de seus bens privados. O aparelho do Estado funcionava como uma extensão do poder soberano, e seus auxiliares, servidores, possuíam status de nobreza real. Esse modelo teve início na Idade Média, predominando nas monarquias absolutistas dos Séculos XV ao XVII, tendo chegado ao fim do Século XIX, quando foi substituído pelo modelo burocrático weberiano.

Uma das consequências do modelo patrimonial é que a corrupção e o nepotismo são facilitados por esse tipo de administração, na qual os cargos públicos são distribuídos através de afeição e troca de favores. Tais cargos são ocupações de maior rentabilidade e de pouco trabalho. No período colonial, o Brasil se encontrava apenas em condição de patrimônio da coroa portuguesa. Funcionários do reino português eram enviados para ocuparem cargos administrativos, sendo estes, nobres e garantidores de status. Porém, tais funcionários, mostravam-se corruptos e infiéis às ordens do rei. Na realidade, não havia limites entre o público e o privado, sendo que tais cargos eram vendidos em benefícios próprios.

Outras situações decorrem do fato de o patrimonialismo afetar a finalidade básica do Estado de resguardar a coisa pública, pois as atividades públicas deixam de estar empenhadas com a melhor relação custo-benefício possíveis para a sociedade. Desta forma, desloca-se o foco de atenção da sociedade para as questões que privilegiam o interesse de poucos.

Exemplos modernos do patrimonialismo e que atualmente encontram-se presentes no Brasil, atuando como parte da gestão pública municipal, estadual e federal, são: parentes de políticos que sem qualquer preparo, são escolhidos para cargos de confiança importantes na Administração Pública, passando em concursos públicos de credibilidade duvidosa; uso de recursos públicos para uso próprio ou para patrocínio de campanhas; empresas patrocinadoras de campanhas eleitorais vencendo licitações duvidosas; utilização de empresas e ONGs fantasmas para associações criminosas com o poder público; etc. 
Torna-se então imprescindível desenvolver uma administração em que não apenas haja clara distinção entre o público e o privado, mas também que seja estabelecida a separação entre o político e o administrador público. É a partir disso que surge a administração burocrática ou modelo burocrático.

\subsection{O Modelo Burocrático}

Não obstante aos argumentos apresentados no modelo patrimonialista, o modelo de administração burocrática diferencia o público do privado. Nele há separação entre o político e o administrador público. Nesse sentido, deu-se o surgimento de burocracias públicas compostas por administradores profissionais com recrutamento e treinamento específicos, que deveriam responder de forma neutra aos políticos. Historicamente, corresponde ao modelo de administração pública predominante, ao longo do século XX, nos Estados democráticos.

De acordo com Gomes e Oliveira (2010), com a ascensão do capitalismo e da democracia, estabeleceu-se uma clara distinção entre a res publicae (“a coisa pública”) e os bens privados. Democracia e Administração Pública Burocrática surgiram com o intuito de proteger o patrimônio público contra a privatização do Estado.

A Democracia foi o instrumento político que resguardou os direitos civis contra a tirania, e a Burocracia foi o instrumento administrativo para combater o nepotismo e a corrupção, adotando princípios de um serviço público profissional e de um sistema administrativo impessoal, formal e racional. A administração burocrática veio substituir as formas patrimonialistas de gestão, ganhando importância pela previsibilidade e precisão no tratamento das questões organizacionais (PEREIRA, 2006). Nesse sentido, foi uma resposta aos abusos e demais vícios experimentados pela Administração Pública, uma vez que se disseminava a ideia de desconfiança prévia dos administradores públicos por parte da sociedade, como uma reação ao modelo patrimonialista.

A administração burocrática se destaca pela ideia de sua submissão ao Direito, de racionalidade, de discernimento entre meios e fins e de precisão. A proposta é de efetivação de um controle rígido dos processos a priori, por exemplo, aqueles inerentes à admissão de pessoal e às contratações a serem realizadas pelo Poder Público, baseando-se nos princípios do formalismo, impessoalidade, profissionalismo, carreira e hierarquia (BRASIL, 1995).

Segundo Secchi (2009), o formalismo, diz respeito aos deveres e responsabilidades aos membros da organização, a documentações escritas dos procedimentos administrativos, a formalização dos processos decisórios, a configuração e legitimidade de uma hierarquia administrativa e a formalização das comunicações tanto internas quanto externas. Com a 
formalidade, as tarefas dos empregados são determinadas de maneira formal de modo a assegurar a continuidade do trabalho e a uniformidade dos serviços prestados, para evitar a discricionariedade individual na execução das rotinas administrativas padronizadas.

$\mathrm{Na}$ prática, o formalismo é uma pequena liberdade concedida aos administradores públicos, para agirem de acordo com o que julgam convenientes e oportunos diante de determinadas situações, não pautados em diretrizes particulares, mas sim, orientados para a satisfação dos direitos coletivos e respeito aos direitos individuais.

No tocante a impessoalidade, mostra que a relação entre os membros de uma instituição e entre a instituição e o ambiente externo, está fundamentada em funções e linhas de autoridade claras. O Diretor ou Chefe é a pessoa que de maneira formal representa a instituição. O Diretor ou Chefe de um departamento tem a autoridade e responsabilidade de decidir e comunicar a seus subordinados esta decisão. Ressalta-se ainda que a impessoalidade implica que as posições hierárquicas são da instituição e não dos Diretores ou Chefes que a estão ocupando. Desta forma, evita a apropriação do individual ao poder, prestígio e outros tipos de benécias, no momento que a pessoa deixa sua função ou a organização (SECCHI, 2009).

O profissionalismo impõe-se ao nepotismo que caracterizava o modelo patrimonialista. Para Gomes e Oliveira (2010), esta característica está ligada ao "valor dado ao mérito como critério de justiça e diferenciação". Para os autores, suas funções são dirigidas às pessoas que aspiram a um cargo por meio de competência justa, na qual os pretendentes ao cargo devem mostrar seus melhores níveis de conhecimento e habilidades técnicas. A promoção do funcionário para cargos mais altos na hierarquia vai depender da experiência e desempenho na função.

São ainda atributos do profissionalismo o trabalho remunerado, a divisão racional de tarefas, a distinção das propriedades pública e privada e dos ambientes de vida pessoal e de trabalho. Ainda no que diz respeito ao profissionalismo, pode-se inferir que o modelo burocrático acolheu a ideia taylorista de potencializar o rendimento funcional através da separação das funções de planejamento e execução de tarefas.

Para Weber apud Gomes e Oliveira (2010), tais características tornam a burocracia capaz de um alto grau de eficiência organizacional. Entretanto, Lane apud Gomes e Oliveira (2010), critica o modelo weberiano, argumentando o seguinte:

Isso (a transição de uma relação pessoal para uma impessoal) pode ser um passo no sentido de uma maior eficiência no sentido absoluto. Entretanto, temos aqui uma espécie de falácia: o fato de um burocrata ser dedicado ao seu cargo não implica que o problema da motivação está resolvido; pode ser que ele seja assim dedicado 
porque maximiza sua utilidade pessoal, ou porque deseja ser útil no trabalho. Estes dois objetivos não podem garantir eficiência (LANE, 1993, p. 50).

Nesse contexto, o modelo de administração em questão, parte de uma desconfiança antecipada nos administradores públicos e nos cidadãos que a eles dirigem demandas. Por este motivo, é sempre necessário o controle rígido dos processos.

Em contrapartida, surgem disfunções, o controle - a garantia do poder do Estado transforma-se na própria razão de ser da administração. Desta forma, o Estado corre o risco de voltar-se para si mesmo, perdendo a noção de sua missão básica, que é servir à sociedade. A qualidade essencial da administração pública burocrática é a efetividade no controle dos abusos; seu defeito, por outro lado, está na ineficiência, na auto referência, na incapacidade de voltar-se para o serviço aos seus cidadãos. Esse defeito, entretanto, não se revelou determinante na época do surgimento da administração pública burocrática, porque os serviços do Estado eram menores. Nesse modelo de administração pública, o Estado concentra esforços para manter a ordem, administrar a justiça e garantir os contratos e a propriedade (KLERING, PORSSE; GUADAGNIN, 2010).

Nesse contexto, o modelo de administração burocrática associada ao controle rígido dos processos, ocasiona o excesso de formalismo, de documentação e de papelório, não garantindo rapidez, boa qualidade e nem custo baixo para os serviços prestados ao público. Dessa forma, enquanto o Estado era mínimo, a eficiência não era considerada essencial, porém, com o aumento do Estado, a administração burocrática era tida como lenta, cara, pouco ou nada orientada para o atendimento das demandas dos cidadãos o que, consequentemente, levava à ineficiência.

\subsection{O Modelo Gerencial}

A partir da década de 1970, como resposta à ampliação das funções econômicas e sociais, ao desenvolvimento tecnológico e à globalização, o Estado, pautado no modelo burocrático, foi exposto a questionamentos que o colocaram em xeque. A chegada das inovações tecnológicas advindas da globalização enfraqueceu os controles governamentais existentes. O modelo burocrático, com austeros controles e procedimentos, não mais atendia às necessidades da Administração Pública.

Surge assim, o modelo gerencial de Administração Pública, com uma busca de excelência administrativa e foco no cidadão. Com o modelo gerencial, a capacidade de gestão toma o centro da discussão da Administração Pública. 
Neste modelo, a administração pública procura responder tanto às novas conjunturas do mundo atual, em que estão sendo revistas as funções e as formas de agir do Estado, como acolher às exigências das democracias de massa contemporânea, na qual a funcionalidade e o poder das burocracias estatais têm sido sucessivamente interpelados.

A administração gerencial empenhada em renovar a administração burocrática, tem por base as seguintes diretrizes (CADERNOS MARE DA REFORMA DO ESTADO, 1998, p. 10):

$\checkmark$ a descentralização política, transferindo recursos e atribuições para os níveis regionais e locais;

$\checkmark$ a descentralização administrativa, por meio da delegação de autoridade aos administradores públicos, transformados em gerentes crescentemente autônomos;

$\checkmark$ a adoção de formatos organizacionais com poucos níveis hierárquicos, ao invés das estruturas piramidais;

$\checkmark$ a flexibilidade organizacional, em lugar de estruturas unitárias e monolíticas, compatível com a multiplicidade, a competição administrada e o conflito;

$\checkmark$ a adoção do pressuposto da confiança limitada em substituição à desconfiança total em relação aos funcionários e dirigentes;

$\checkmark$ o controle por resultados, a posteriori, ao invés do controle rígido, passo a passo, dos processos administrativos; $\mathrm{e}$

$\checkmark$ a administração voltada para o atendimento do cidadão e aberta ao controle social. A administração pública gerencial está baseada em uma concepção de Estado e de sociedade democrática e plural, que considera a complexidade política e administrativa do Estado, cujos aparatos também estão permeados pelo conflito e pela interação direta com as demandas da sociedade.

Contudo, sem que o modelo anterior seja integralmente abandonado, nenhum modelo de administração extingue totalmente os procedimentos do modelo preexistente, havendo sempre uma continuidade. No caso da mudança do modelo burocrático para o gerencial, houve certo rompimento, contudo, alguns princípios foram preservados de forma flexível, tais como a admissão por critérios de mérito, sistema estruturado e universal de remuneração, as carreiras, avaliação de desempenho e o treinamento (BRASIL, 1995). Porém, a principal característica inerente à mudança do modelo burocrático para o modelo gerencial, refere-se à forma de controle que anteriormente era realizada a priori e focava-se nos processos, passando a centralizar-se nos resultados e a ser feita a posteriori. Há ainda, uma evolução no sentido do interesse público. No modelo gerencial, o interesse público passa a ter como foco o 
atendimento dos ensejos do cidadão, contribuinte de impostos e destinatário de serviços, enquanto no modelo burocrático o interesse público acabava-se associando ao próprio interesse do aparato do Estado.

Nesse contexto, o modelo gerencial de gestão pública passa a ser baseado nos critérios de valores de eficiência, eficácia, qualidade e desempenho, aproximando a ação estatal das administrações privadas que buscam sempre atingir resultados, minimizar os custos e reduzir os controles das atividades-meio. Nele, os conceitos de eficiência e eficácia, por vezes, são usados de forma uniforme. A eficiência está voltada para a melhor maneira pela qual as coisas devem ser realizadas, uma relação custo/benefício, ou seja, a melhor utilização dos recursos disponíveis. Já a eficácia pode ser entendida como o alcance dos objetivos através dos recursos disponíveis, ou seja, o alcance dos resultados.

Desta forma, parte-se da ideia de que todo desempenho pode ser mensurado focandose os resultados - que devem ser medidos em comparação com as expectativas - e o cidadão beneficiário, ou cidadão cliente. A ideia de avaliação de desempenho, entre outros princípios que norteiam a Administração Pública Gerencial, teve como pretensão o uso de práticas de gestão provenientes da administração privada. Contudo, devem-se levar em conta certas diferenças, como o objetivo (de lucro, no caso das organizações privadas, e, da realização do interesse público, no caso da Administração Pública) e a origem das receitas.

Entretanto, segundo Ormond e Loffler (1999, p. 66-96), considerando que cada reforma deve ter raízes na configuração histórica e nas tradições de cada nação, nas estruturas legais, nas forças políticas e administrativas, nas perspectivas econômicas e sociais e na posição internacional do país, não existe um modelo único que discuta e resolva todas as necessidades de cada país.

Gomes e Oliveira (2010) avaliam que:

As nações não devem ficar presas a conceitos e receitas de nova administração, nem a preconceitos da antiga Administração Pública. O modelo único e perfeito jamais existirá em uma forma ideal. Uma questão muito discutida no modelo gerencial é a ampliação para as relações de responsabilidades (accountability) entre os gerentes públicos, os servidores, os ministérios, as secretarias, as autoridades políticas, os cidadãos, o Poder Legislativo e o Poder Executivo. Na gestão gerencial, o comprometimento com o resultado tornou-se um instrumental que promoverá mecanismos de responsabilidade.

Gabardo (2003), em sua obra "Eficiência e Legitimidade do Estado", assim contextualiza o princípio da eficiência:

No Brasil, a eficiência tornou-se princípio constitucional expresso a partir da Emenda Constitucional no 19/88, que alterou a redação do caput do artigo 37. Isso não implica afirmar que a reforma introduziu uma novidade no sistema administrativo nacional. O princípio constitucional da eficiência administrativa já 
se denotava implícito na Carta Magna. Assim sendo, é importante considerar que a natureza da eficiência como norma constitucional não compreenderá a essência neoliberal que permeou os trabalhos reformadores. A eficiência como mero símbolo ou valor ideológico não se confunde com a sua manifestação jurídica normativa (GABARDO, 2003, p. 185).

Para Sarturi (2013),

Com a adoção do modelo de Estado Gerencial no Brasil, o que ocorreu, basicamente, com o advento da Emenda Constitucional supracitada, ganhou importância à participação das entidades não governamentais na realização de políticas públicas. A prestação de serviços públicos não exclusivos do Estado, ou seja, não correspondentes à manifestação de uma feição do poder do Estado, como o poder de polícia, ganhou novos modelos. Trata-se do estabelecimento de parceria com o Terceiro Setor para prestação de serviços como saúde, educação, pesquisa científica, fomento, entre outros. A prestação de serviços públicos por intermédio de agentes não estatais, atuando sob formas menos rígidas e sujeita ao controle estatal quanto aos resultados, é aplicação prática do princípio da eficiência. Tal mudança visa, na verdade, ao acréscimo de qualidade na prestação dos serviços públicos sociais, perdida com a crise de financiamento que levou à derrocada do Estado Social (SARTURI, 2013).

De acordo com Filho (2009),

O primeiro grande passo para mudar o desempenho do Estado como prestador de serviços foi o Programa Nacional de Desestatização, instituído pela Lei n ${ }^{\circ} 8.031$, de 12.04.1990. Posteriormente, essa Lei foi revogada pela Lei $\mathrm{n}^{\circ}$ 9.491, de 09.09.1997, que, embora alterando procedimentos previstos na lei anterior, manteve as linhas básicas do Programa (FILHO 2009, p. 331).

Nesse sentido, de acordo com Pereira (1996), com o intuito de buscar uma flexibilização da administração com maior eficiência nas atividades econômicas, através de um programa de publicização, demovem-se para as autarquias, fundações, empresas públicas e sociedades de economias mistas, a produção dos serviços competitivos ou não exclusivos de Estado, constituindo-se em um sistema de parceria entre Estado e a sociedade para o seu financiamento e controle, consagrando e racionalizando uma situação que já se delineava na prática.

No modelo de Administração Gerencial estabelece-se ainda, a figura dos entes de cooperação que apoiam o Estado e são também referenciados de entes paraestatais. Alguns autores habitualmente referem-se a eles como terceiro setor. Para eles, uma vez que os mesmos estão fora da administração, sua natureza jurídica é de pessoa jurídica de direito privado. Essas pessoas jurídicas não possuem fins lucrativos e nem tampouco foram originadas para o lucro, que, se ocasionalmente acontecer, deve ser enquadrado nas funções institucionais, mas não é seu principal objetivo.

Di Pietro (2003, p. 413/414), ao analisar o chamado "terceiro setor", explica que,

Nesse mesmo sentido de entidades paralelas ao Estado, podem ser incluídas, hoje, além dos serviços sociais autônomos, também as entidades de apoio (em especial 
fundações, associações e cooperativas), as chamadas organizações sociais e as organizações da sociedade civil de interesse público.

(...)

Em todas essas entidades estão presentes os mesmos traços: são entidades privadas, no sentido de que são instituídas por particulares; desempenham serviços não exclusivos do Estado, porém em colaboração com ele; recebem algum tipo de incentivo do poder público; por essa razão, sujeitam-se a controle pela Administração Pública e pelo Tribunal de Contas. Seu regime jurídico é predominantemente de direito privado, porém parcialmente derrogado por normas de direito público. Integram o terceiro setor, porque nem se enquadram inteiramente como entidades privadas, nem integram a Administração Pública, direta ou indireta. Incluem-se entre as chamadas organizações não governamentais (ONGs). Todas essas entidades enquadram-se na expressão entidade paraestatal.

Ainda com relação ao modelo de administração gerencial, existe uma flexibilização no tocante à organização administrativa em relação ao modelo burocrático. Enquanto no modelo burocrático a estrutura administrativa configurava-se de forma mais severa, sempre pautada na observância de regulamentos, procedimentos e normas legais, o modelo gerencial propõe uma maior descentralização político-administrativa, com transferência de funções para administrações locais, dotadas de maior autonomia e responsabilidade. Dessa forma, a proposta é de uma organização administrativa com menos níveis hierárquicos, com controle de resultados e voltada para o atendimento das necessidades dos administrados (PEREIRA, 1996).

Nesse contexto, são características da administração pública gerencial (PEREIRA, 1997, p. 42):

$\checkmark$ Ênfase no controle dos resultados através dos contratos de gestão (ao invés de controle dos procedimentos);

$\checkmark$ Orientação da ação do Estado para o cidadão-usuário ou cidadão-cliente;

$\checkmark$ Fortalecimento e aumento da autonomia da burocracia estatal, organizada em carreiras de Estado, e valorização do seu trabalho técnico e político de participar, juntamente com os políticos e a sociedade, da formulação e gestão das políticas públicas;

$\checkmark$ Separação entre as secretarias formuladoras de políticas públicas, de caráter centralizado, e as unidades descentralizadas, executoras dessas mesmas políticas;

$\checkmark$ Distinção de dois tipos de unidades descentralizadas: as agências executivas, que realizam atividades exclusivas de Estado, monopolistas por definição, e os serviços sociais e científicos de caráter competitivo, em que o poder de Estado não está envolvido;

$\checkmark$ Transferência para o setor público não-estatal dos serviços sociais e científicos competitivos; 
$\checkmark$ Adoção cumulativa, para controlar as unidades descentralizadas, dos mecanismos: (1) de controle social direto, (2) do contrato de gestão em que os indicadores de desempenho sejam claramente definidos e os resultados medidos, e (3) da formação de quase mercados em que ocorre a competição administrada;

$\checkmark$ Terceirização das atividades auxiliares ou de apoio, que passam a ser licitadas competitivamente no mercado.

Em sua visão sobre os norteadores da gestão pública atual, Linhares (200-?) alertou para os seguintes pontos:

Figura 1 - Pontos norteadores da Gestão Pública Atual

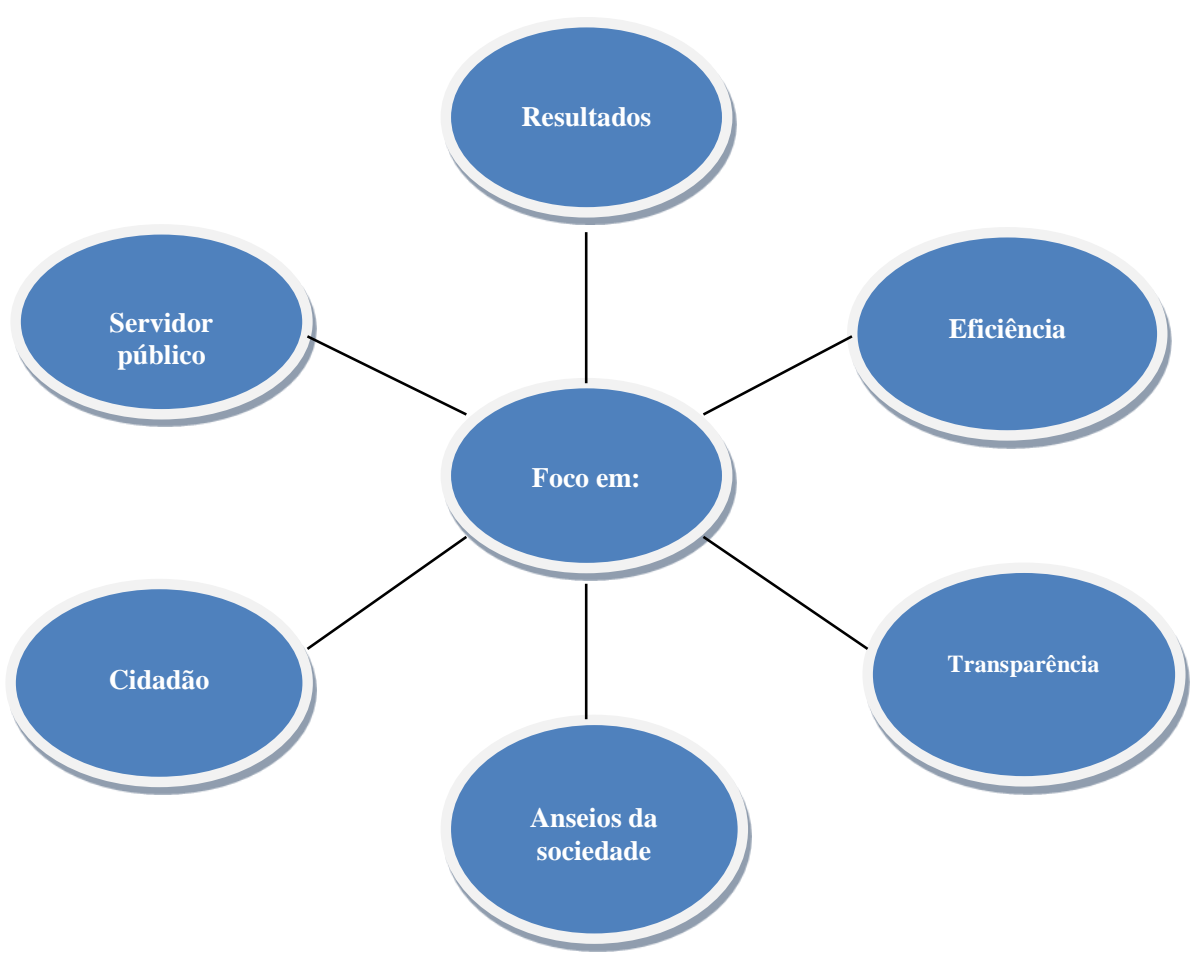

Fonte: Linhares (200-?)

Abordando cada um deles, temos o seguinte:

$\checkmark$ Enfoque nos resultados, com monitoramento das atividades e avaliação de seus resultados.

$\checkmark$ Foco na eficiência das atividades, com redução dos gastos públicos, melhor qualidade e maior quantidade de serviços gerados à população. Eliminação dos desperdícios, tanto de consumo quanto de tempo dos funcionários, ao simplificar os procedimentos operacionais.

$\checkmark$ Foco na transparência, com respeito ao cidadão. Definição de canais adequados de participação. Um exemplo disso é o pregão eletrônico, modalidade de licitação à qual 
qualquer cidadão brasileiro pode ter acesso em tempo real, acompanhando a comunicação entre comprador e fornecedor, e os preços firmados.

$\checkmark$ Foco na incorporação dos "anseios" da sociedade com planejamento participativo e definição de mecanismos que englobem amplitude e diversificação de demandas Administração Pública Federal.

$\checkmark$ Foco no cidadão, encurtando e facilitando o canal de comunicação entre eles e as entidades públicas.

$\checkmark$ E o enfoque naquele que é a mola mestra para que tudo aconteça no serviço público, o servidor. Ele precisa ser motivado, engajado e conhecedor das atividades que sua empresa desenvolve e, o mais importante, um especialista nas atividades que ele precisa executar. A profissionalização do servidor público é fundamental para um desempenho melhor da gestão pública. E o quadro funcional das organizações deve estar adequado às suas necessidades, de modo que consigam, assim, gerar os resultados pretendidos.

No que diz respeito à autonomia dos órgãos e entidades públicas, esta é maior no gerencialismo em virtude de um acordo firmado entre o Poder Executivo e seus dirigentes, através do qual ficam estabelecidos metas e objetivos claros para o alcance dos resultados (OLIVEIRA, 2008, p. 320).

Dessa forma, na Administração Pública Gerencial estabelecem-se os objetivos que devem ser alcançados através de uma ação pública, atribuindo ao administrador autonomia na gestão dos recursos e propondo um controle a posteriori do alcance dos resultados propostos.

\subsection{Gestão Pública por Resultados}

As regras da eficácia gerencial estão regulamentando o que Osborne e Gaebler (1998) chamam de "governo por resultados, com foco no cidadão, que é o seu cliente, na procura de maior qualidade e menor custo, no governo empreendedor, competitivo, orientado por missões e objetivos e canalizado para o mercado".

Nesse sentido a gestão por resultados é um modelo administrativo que, através de sua metodologia, nivela o planejamento, a avaliação e o controle, fomentando eficiência e eficácia na organização. No tocante a eficiência, diz respeito a usar com economia, zelo e dedicação, os bens e os recursos públicos. Em relação à eficácia, refere-se ao comprometimento competente do planejamento e cumprimento responsável pela sua execução. A gestão por resultados apresenta ainda, foco na efetividade e na flexibilização dos processos, reduzindo o 
excessivo apego às normas e procedimentos, proporcionando mais eficiência, efetividade e accountability à gestão pública. $\mathrm{O}$ foco na efetividade refere-se a atingir os resultados sociais aspirados pela sociedade, oferecendo-lhes serviços de interesse social compatíveis com suas necessidades em extensão, qualidade e preços.

Trosa apud Ribeiro et al. (2011) avalia que se pode assimilar que accountability é o dever dos funcionários em prestar contas quali-quantitativamente, a qualquer momento, dos serviços prestados. Já a responsabilidade é a tendência espontânea para o dever de galgar os resultados e deles prestar contas, caracterizando-se como o reverso positivo da accountability.

De forma breve, a Gestão por Resultados caracteriza-se na etapa de formulação da política pública, pela tradução dos objetivos em resultados e, na etapa de implementação das ações para atingi-los, pela prevalência da orientação por resultados em substituição aos outros mecanismos de coordenação, como a coordenação por supervisão direta, a padronização de procedimentos e de habilidades. Trosa apud Batista e Maldonado (2008) alerta ainda que o serviço público não pode ficar à margem da progressão natural das corporações, sejam eles o intercâmbio das informações, a elevação do nível de qualificação dos funcionários, ou mesmo o interesse pelo que os servidores efetivamente estão produzindo em atividades nos órgãos públicos.

Do mesmo modo que o fazem as grandes empresas contemporâneas, as instituições públicas devem ser flexíveis e adaptáveis, proporcionando serviços eficientes. O governo deve ser empreendedor e criativo, objetivando buscar novas formas de obter receitas com aqueles serviços que oferece. Deve pensar no retorno de seus investimentos e não centrar apenas nos gastos. Enfim, deve ter uma visão de futuro, e tomar decisões baseadas nessa visão (OSBORNE E GABLER, 1998).

A gestão empreendedora é centralizada no controle dos resultados, nas saídas, ao contrário da administração burocrática, que visa mais os recursos, as entradas. O interesse da gestão pública empreendedora é aperfeiçoar os princípios da administração burocrática. Entretanto, não é administrar o Governo simplesmente como quem administra uma empresa, porque a empresa privada tem por propósito direto o lucro, monetário. O governo visa o bem comum, sem fins lucrativos (CATELLI et al., 2001).

Nesse sentido, uma gestão empreendedora para administrar o Governo precisa desenvolver a capacidade de mudanças, metas e planejamento bem como soluções para possíveis e imprevisíveis problemas de ordem social, política e econômica. Tudo isto sendo observado pela ótica pública, onde os recursos são escassos e as necessidades em grandes proporções. Desta forma, possibilitará a elevação nos padrões de prestação de serviços, justa 
distribuição e alocação dos recursos públicos e a desburocratização dos processos administrativos.

Ser burocrático ou empreendedor não é um benefício de empresas públicas. Qualquer empresa, pública ou privada, pode ter sua gestão focada para a linha burocrática ou com um cunho mais empreendedor.

Catelli et al. (2001), avaliam que qualquer unidade da administração pública pode ter uma gestão com enfoque nos resultados, com uma avaliação econômica das suas atividades, uma vez que trabalham com um orçamento monetário, o que não quer dizer que seja fácil calcular seus benefícios.

São consideradas funções da gestão por resultados (HILÁRIO apud RIBEIRO et al., 2011):

$\checkmark$ Definir a direção estratégica da organização - criação da missão e estabelecimento dos objetivos estratégicos, levando em consideração a visão e os valores da organização. Refere-se à definição do caminho que deverá ser seguido para alcançar os objetivos estratégicos. É necessário mapear os processos de trabalho e escolher os indicadores e as metas de desempenho que mostrarão se a organização está no caminho planejado e, através de uma avaliação, o quanto de progresso foi feito na direção dos objetivos;

$\checkmark$ Implementar e administrar o processo de mudança alinhado com a direção estratégica - compromisso da organização com a ação;

$\checkmark$ Melhorar continuamente o desempenho das atividades em andamento - garantia que a melhoria contínua seja praticada em cada programa ou atividade da organização através de planos de ação frequentemente monitorados.

Segundo Gomes (2009), pode-se compreender que a gestão por resultados é desenvolvida por meio de um ciclo que começa com o estabelecimento dos resultados desejados, a partir da tradução dos objetivos; seguido do monitoramento e da avaliação do desempenho da organização a partir do alcance desses resultados; e retroalimentação do sistema de gestão, propiciando ações corretivas decorrentes dessa avaliação.

Ribeiro et al. (2011), asseveram que além desse esquema básico, como o modelo confere grande autonomia processual aos agentes executores, compõe ainda sua estrutura o seguinte:

$\checkmark$ Alinhamento de expectativas de forma clara e transparente, entre todos os colaboradores, por meio da tradução destas em resultados e metas a serem atingidos, o que inclui a definição de indicadores para sua apuração;

$\checkmark$ Concessão de autonomias aos executores / implementadores da gestão estratégica; 
$\checkmark$ Contratualização de resultados, autonomias e sanções;

$\checkmark$ Avaliação dos resultados e retroalimentação do sistema de gestão para eventuais correções de rota, constituindo assim uma ferramenta gerencial;

$\checkmark$ Fortalecimento de uma modalidade de "accountability" - baseada no desempenho mensurado a partir de indicadores de resultados;

$\checkmark$ Modificação do comportamento peculiar da burocracia, substituindo-o pela atenção a metas claras e contratualizadas.

Nesse aspecto, a vantagem aguardada do modelo de gestão pública por resultado para o aumento da eficiência da administração pública leva-nos a crer que é bastante evidente. A transparência dos objetivos, resultados e metas da organização tende a minimizar os problemas relacionados aos gap's de informação e modernização dos processos de trabalho, possibilitando o compartilhamento e a participação coletiva em torno dos mesmos objetivos, o que contribui para a racionalidade do sistema e da organização. Além disso, permite ainda maior efetividade sobre o desempenho dos funcionários, pelos clientes e demais stakeholders. Finalmente, confere aos gestores autonomia sobre a gestão dos recursos, acarretando adequação eficiente entre recursos, processos e metas. 


\section{O PRINCÍPIO DA EFICIÊNCIA}

Ao se pesquisar a origem do Princípio da Eficiência, seria mais adequado relacioná-lo ao princípio do bom administrador, presente na obra de Hely Lopes Meirelles (1989). Moreira Neto entende da mesma maneira:

[...] resultado de um consistente e inovador trabalho da doutrina jurídica, desenvolvida desde a metade do século XX, exibindo nomes como Raffaele Resta e Guido Falzonem na intenção de superar o conceito de poder-dever de administrar, afirmado pela administração burocrática, comprometida em lograr somente a eficácia jurídica, para fixar como um passo adiante, o dever de bem administrar, que hoje é respaldado pelos modernos conceitos gerenciais, voltados à eficiência da ação da administração pública. (MOREIRA NETO, 1999, p. 67)

No entendimento de Vetoratto (2001, p. 172):

Eficiência como princípio da Administração pública tem origem junto ao nascimento das grandes teorias das ciências administrativas. Entre os seus idealizadores estariam TAYLOR, FAYOL e WEBER, pois foram eles que definiram inicialmente o seu conteúdo princípio lógico.

Vetoratto (2001, p. 178) expressa da seguinte forma, a maneira de justificar a posição anteriormente citada:

FAYOL foi o primeiro a definir as características do bom administrador, bem como os princípios da administração geral. TAYLOR teve sua principal preocupação do estudo dos melhores meios como forma de obtenção do fim buscado pela organização. E, finalmente, WEBER caracterizou as organizações sociais, analisando a sua juridicidade e a eficiência como princípio para a obtenção de seus fins.

O Princípio da Eficiência no Brasil foi incorporado ao caput do artigo 37 da Constituição Federal por meio da Emenda Constitucional n ${ }^{\circ}$ 19/98. A partir de então, a Administração Pública passou, claramente, a ter o dever de ser eficiente.

A doutrina administrativista tem procurado interpretar esse Princípio, agora especificado na Constituição. Mello (2002, p. 104) entende que ele "mais parece um adorno agregado ao art. 37”, que não pode ser criado "senão na intimidade do princípio da legalidade" e, finalmente, que "é uma faceta de um princípio mais amplo, já superiormente tratado, de há muito, no Direito italiano: o princípio da boa administração”.

A Lei Ordinária Federal nº 9.784, de 29/01/1999, que trata do processo administrativo no âmbito federal, em seu artigo $2 .^{\circ}$, também introduziu a eficiência como um dos princípios orientadores da Administração Pública anexado aos da Legalidade, do Objetivo, da Motivação, da Razoabilidade, da Proporcionalidade, da Moralidade, da Ampla Defesa, do Contraditório, da Segurança Jurídica e do Interesse Público. É evidente que um sistema 
moldado pelos Princípios da Moralidade de um lado, e do Objetivo, de outro, não poderia admitir a ineficiência administrativa. Por esse motivo, a EC nº $19 / 98$ não trouxe modificações no regime constitucional da Administração Pública, só explicitou um comando até então implícito.

As regras não são qualificadas pela eficiência, mas, sim, as atividades. Genericamente, a eficiência significa executar as atividades com racionalidade, implica avaliar os custos que a realização das necessidades públicas importa em relação ao grau de utilidade obtido. Assim, o Princípio da Eficiência conduz a atividade administrativa com a finalidade de obter os melhores resultados com os meios limitados de que se dispõe e a custos reduzidos. Logo, o mesmo é orientado pela regra de consecução do maior benefício com o mínimo possível de recursos.

Nesse sentido, Meirelles (1996, p. 90-91), avalia eficiência como um dos deveres da Administração Pública, definindo-a como:

O que se impõe a todo agente público de realizar suas atribuições com presteza, perfeição e rendimento funcional. É o mais moderno princípio da função administrativa, que já não se contenta em ser desempenhada apenas com legalidade, exigindo resultados positivos para o serviço público e satisfatório atendimento das necessidades da comunidade e de seus membros.

Corroborando com este entendimento, Di Pietro (2002, p. 83) afirma que "uma administração eficiente pressupõe qualidade, presteza e resultados positivos, constituindo, em termos de Administração Pública, um dever de mostrar rendimento funcional, perfeição e rapidez dos interesses coletivos".

Para Moraes (2002, p. 67) o Princípio da Eficiência pode ser definido como aquele que:

(...) impõe à Administração Pública Direta e Indireta e a seus agentes a persecução do bem comum, por meio do exercício de suas competências de forma imparcial, neutra, transparente, participativa, eficaz, sem burocracia, e sempre em busca da qualidade, primando pela adoção dos critérios legais e morais necessários para a melhor utilização possível dos recursos públicos, de maneira a evitar desperdícios e garantir-se uma maior rentabilidade social.

Nesse entendimento, é importante destacar que, se o Poder Público não aproveitar da forma mais adequada todos os recursos humanos, materiais, técnicos e financeiros a seu alcance, no exercício de suas competências, a eficiência na busca do bem comum, conforme preceitua a Constituição Federal, jamais será atendida.

Desta forma, Moraes (1999, p. 150) afirma o seguinte:

Ser eficiente, portanto, exige primeiro da Administração Pública o aproveitamento máximo de tudo aquilo que a coletividade possui, em todos os níveis, ao longo da realização de suas atividades. Significa racionalidade e aproveitamento máximo das potencialidades existentes. Mas não só. Em seu sentido jurídico, a expressão, que 
consideramos correta, também deve abarcar a ideia de eficácia da prestação, ou de resultados da atividade realizada. Uma atuação estatal só será juridicamente eficiente quando seu resultado quantitativo e qualitativo for satisfatório, levando-se em conta o universo possível de atendimento das necessidades existentes e os meios disponíveis. (MORAES, 1999, p. 150).

Assevera ainda o autor que:

Desse modo, pode-se definir esse princípio como sendo aquele que determina aos órgãos e pessoas da Administração Direta e Indireta que, na busca das finalidades estabelecidas pela ordem jurídica, tenham uma ação instrumental adequada, constituída pelo aproveitamento maximizado e racional dos recursos humanos, materiais, técnicos e financeiros disponíveis, de modo que possa alcançar o melhor resultado quantitativo e qualitativo possível, em face das necessidades públicas existentes. (MORAES, 1999, p.166).

A Constituição Federal procurou semelhantemente fortalecer o sentido valorativo do Princípio da Economicidade, que, adicionado literalmente pelo artigo 70, interpreta o dever de eficiência do administrado na gestão do dinheiro público:

Art. 70. A fiscalização contábil, financeira, orçamentária, operacional e patrimonial da União e das entidades da administração direta e indireta, quanto à legalidade, legitimidade, economicidade, aplicação das subvenções e renúncia de receitas, será exercida pelo Congresso Nacional, mediante controle externo, e pelo sistema de controle interno de cada Poder.

A ideia de eficiência administrativa não deve estar ligada somente ao aproveitamento dos meios e recursos disponibilizados aos agentes públicos, mas também à adequação lógica desses meios, coerentemente utilizados para a consecução dos resultados efetivamente obtidos, e à relação adequada desses resultados com as necessidades públicas existentes.

O Princípio da Eficiência é um instrumento de vital importância para fazer exigir a qualidade dos serviços e produtos oriundos do Estado. Segundo Di Pietro (1999), o entendimento do Princípio da Eficiência pode ser parametrizado a partir de duas vertentes distintas: uma diz respeito à atuação do agente público, do qual se espera o melhor desempenho possível e o alcance de resultados condizentes com suas atribuições; a outra se relaciona à visualização da eficiência como uma derivação da organização, estruturação e disciplinamento racional da Administração Pública na busca de resultados satisfatórios na prestação pública de serviços.

Em relação à atuação do agente público, convém esclarecer que para que os serviços públicos sejam prestados com eficiência, faz-se necessária a regulação de suas ações. Nessa linha, o maior objetivo dessa regulação foi mudar a mentalidade do servidor, implementando uma atuação idêntica a que é executada no setor privado, de maximização dos resultados, redução de custos e satisfação do cliente, tudo isso utilizando os meios de que se dispõe. Nesse contexto, é imprescindível uma melhor performance do agente público, e, uma melhor 
organização e estruturação por parte da administração pública, com vistas a produção de resultados positivos e satisfatórios às necessidades da sociedade.

O princípio da eficiência não pode ser tido como letra esquecida em nossa constituição. Assim, a administração pública deve dispor de mecanismos que fiscalize e torne esse princípio mais efetivo nos órgãos públicos, como por exemplo, propor a capacitação dos agentes públicos, pois a ausência de profissionalização do pessoal, a desorganização e a má distribuição interna, são fatores que impedem a qualidade e produtividade do serviço público.

Nesse contexto, Alcântara (2009) avalia que a eficiência é de difícil operacionalização, ainda mais em serviços públicos. Para o autor, grande parte das atividades públicas não permite uma avaliação direta e objetiva dos resultados, pois elas atuam em sistemas abertos e complexos. Já a avaliação da eficácia do serviço público é um desafio ainda maior do que a análise sobre a eficiência, especialmente porque a eficácia, em geral, está relacionada à definição e possível consecução de objetivos, que muitas vezes estarão no âmbito da discricionariedade do administrador público.

Nessa linha de raciocínio é importante frisar que a impossibilidade de atingir os melhores resultados sem o vínculo constante do planejamento, da ação e do controle é notoriamente evidenciada na própria definição de eficiência e eficácia. As diferenças entre eficiência e eficácia podem até parecerem imperceptíveis, mas, na realidade, são extremamente importantes.

De acordo com Peña (2008), eficiência é a capacidade de "fazer certo as coisas, de minimizar a relação insumos-produtos". Logo, ser eficiente significa realizar um trabalho de forma correta, sem erros e de boa qualidade, constituindo assim, uma relação entre os resultados que se conseguiu alcançar e os recursos que se empregaram.

Ser eficaz é fazer um trabalho que consiga atingir um resultado esperado na totalidade. Em outras palavras, é o confronto entre o que se pretendia fazer e o que efetivamente se conseguiu. Penã (2008) avalia que eficácia implica "fazer as coisas certas, escolher objetivos" e, adicionando mais um ponto, pode-se dizer que, no momento adequado. A eficácia é medida pelos resultados realmente alcançados.

Portanto, a união dos dois conceitos é essencial para o cumprimento desejado, porém nem todo administrador possui as duas qualidades. Para o administrador, a eficácia é a mais importante, contudo, é imprescindível que o mesmo apresente os resultados esperados, pois na atualidade são o que as empresas cobram em primeiro lugar. Já a eficácia aliada à eficiência é mais trabalhosa de se encontrar nos profissionais atuais, pois, alguém eficaz e 
eficiente, apresenta os resultados esperados em curto prazo, com qualidade e sem cometer muitos erros, e nesse caso, seria o administrador ideal.

Bio (1996) assevera que "eficiência diz respeito a método, a modo certo de fazer as coisas, (...) uma empresa eficiente é aquela que consegue o seu volume de produção com o menor dispêndio possível de recursos. Portanto, ao menor custo por unidade produzida”. Já a “eficácia diz respeito a resultados, produtos decorrentes de uma atividade qualquer. Trata-se da escolha da solução certa para determinado problema ou necessidade. (...) uma empresa eficaz coloca no mercado o volume pretendido do produto certo para determinada necessidade”. Porém, o autor vincula a eficácia à eficiência “(...) a eficácia depende não somente do acerto das decisões estratégicas e das ações tomadas no ambiente externo, mas também do nível de eficiência (...)" (BIO, 1996, p. 22).

Segundo Mendonça (2008), a teoria dos sistemas ressalta que a eficácia é uma importante dimensão para os administradores, definindo-a como o grau em que os resultados de uma organização correspondem às necessidades e aos desejos do ambiente externo. Para o autor, o ambiente externo é constituído de grupos como consumidores, fornecedores, concorrentes e órgãos reguladores. Mesmo uma empresa que tenha o domínio das técnicas de administração científica de Taylor e tenha se tornado extremamente eficiente, é vulnerável se não considerar a eficácia de seus resultados.

Nesse entendimento a eficiência não se preocupa apenas com a sua finalidade, mas tão somente com os meios, ela se insere nas operações, voltada para os aspectos internos da organização. Logo, quem se preocupa com os fins, em alcançar os objetivos é a eficácia, que se insere no êxito do alcance dos objetivos, com foco nos aspectos externos da organização.

Certamente, toda a sociedade almeja que os serviços públicos sejam realizados com adequação às suas necessidades, já que todos contribuem efetiva e incondicionalmente para a arrecadação das receitas públicas. Nesse aspecto, a interligação do Princípio da Eficiência com os da Razoabilidade e da Moralidade é notória, pois o administrador deve se utilizar de critérios razoáveis na realização de sua atividade discricionária. 


\section{GESTÃO DE COMPRAS PÚBLICAS}

\subsection{Breve histórico sobre licitações públicas no Brasil}

Segundo os autores Souza e Castro (2012), a licitação foi inserida no direito público brasileiro há mais de cento e quarenta anos, com a finalidade de regulamentar as arrematações dos serviços a cargo do então Ministério da Agricultura, Comércio e Obras Públicas. Após o advento de diversas outras leis que trataram, de forma franca do assunto, o procedimento licitatório veio, afinal, a ser consolidado no âmbito federal em janeiro de 1922, viabilizando assim, a organização do Código de Contabilidade da União.

O procedimento licitatório veio evoluindo, com o objetivo de possibilitar maior eficiência às contratações públicas, sendo, por fim, sistematizado através de Decreto-Lei publicado em 1967, estabelecendo a reforma administrativa federal, e, estendido em junho de 1968, às Administrações dos Estados e Municípios.

O Decreto-lei $\mathrm{n}^{\mathrm{o}}$ 2.300, de 21.11.86, atualizado em 1987, pelos Decretos-lei $\mathrm{n}^{\mathrm{o}} \mathrm{s} .2 .348$ e 2.360 estabeleceu, pela primeira vez, o Estatuto Jurídico das Licitações e Contratos Administrativos, reunindo normas gerais e especiais relacionadas à matéria.

A Constituição de 1988 representou um considerável progresso na institucionalização e democratização da Administração Pública. Apesar dos textos constitucionais anteriores conterem dispositivos relacionados ao acesso à função pública e ao regime do funcionalismo estatal, a verdadeira constitucionalização da Administração Pública somente foi levada a efeito pela Carta Magna de 1988.

Com a constitucionalização da referida Carta Magna, a licitação recebeu status de princípio constitucional, de observância obrigatória pela Administração Pública direta e indireta de todos os poderes da União, Estados, Distrito Federal e Municípios.

Assim, ao analisar o disposto no art. 37, XXI da Constituição Federal, pode-se observar que a obrigatoriedade de licitar é princípio constitucional, apenas sendo dispensada ou inexigida nos casos expressamente previstos em Lei.

O princípio de licitar está intimamente ligado aos princípios da indisponibilidade e supremacia do interesse público que são princípios balizadores da atividade estatal. O fato de ter sido elevado ao status de princípio constitucional é de extrema importância para a análise do procedimento licitatório dentro do ordenamento jurídico. 
$\mathrm{O}$ art. 37, XXI da Constituição Federal, regulamentado pela Lei no 8.666, de 21.06.93, que normatiza as licitações e contratos da Administração Pública, dispõe expressamente o seguinte:

\begin{abstract}
... ressalvados os casos especificados na legislação, as obras, serviços, compras e alienações serão contratados mediante processo de licitação pública que assegure igualdade de condições a todos os concorrentes com cláusulas que estabeleçam obrigações de pagamento, mantidas as condições efetivas da proposta, nos termos da lei, o qual somente permitirá as exigências de qualificação técnica e econômicas indispensáveis à garantia do cumprimento das obrigações.
\end{abstract}

\title{
5.2 Compras Públicas
}

No Brasil, a Carta Magna em seu artigo 37 estabeleceu os princípios que orientariam a Administração Pública Brasileira, a saber: Legalidade, Impessoalidade, Moralidade e Publicidade. Com o objetivo de delimitar a discricionariedade na Administração Pública, definiu ainda como regra obrigatória no inciso XXI do artigo supracitado, a licitação como antecedente das contratações administrativas.

Dentre os procedimentos licitatórios adotados pela Administração Pública, destacamse as modalidades de licitação tradicionais tais como: concorrência, tomada de preços, convite, e, a nova modalidade de licitação denominada pregão, adequada para obtenção de bens e serviços comuns, cujos padrões de desempenho e qualidade podem ser objetivamente definidos pelo edital e por meio de especificações usuais de mercado.

Esta nova modalidade de licitação Pregão, surgiu como alternativa para otimizar os procedimentos de compras no setor público, sendo instituída no âmbito da União, Estados, Distrito Federal e Municípios, tendo como característica, uma forma de contratar com a Administração Pública muito mais rápida, econômica e transparente, visando minimizar custos através da racionalização e da desburocratização dos processos de compras governamentais, podendo ser realizada de forma presencial ou eletrônica, através da internet.

Assim, a modalidade Pregão em sua forma eletrônica, vem sendo difundida como uma medida inovadora, ousada e a mais importante modalidade de licitação adotada pelo Governo para controlar os processos de compras. A sua utilização preferencialmente na forma eletrônica no âmbito Federal visa atender aos preceitos instituídos em lei a qual dispõe que “... o pregão deve ser utilizado na forma eletrônica, salvo nos casos de comprovada inviabilidade, a ser justificada pela autoridade competente...” (BRASIL, 2005).

Os benefícios advindos do emprego da Tecnologia da Informação e Comunicação (TIC) nesse sistema podem ser expressos em termos de redução da burocracia, ampliação da concorrência em nível nacional e transparência nas operações, porque as mensagens podem 
ser trocadas via chat entre pregoeiro e licitantes, podendo ser acessadas em tempo real ou em forma de ata (FARIA; FERREIRA; SANTOS, 2010).

Acerca do uso de TIC's no que tange a utilização da modalidade Pregão Eletrônico, o ex-presidente da República - Luís Inácio Lula da Silva - explanou que: “É preciso revestir as licitações e contratos públicos de total transparência, mediante a universalização das tecnologias da informação e comunicação e possibilitar à sociedade o acesso a todos os atos dos procedimentos licitatórios" (FELICIDADE; PENA, 2010).

Com o advento da Emenda Constitucional $\mathrm{n}^{\mathrm{o}} 19$ de 1998, foi incorporado aos princípios relatados em linhas passadas, o Princípio da Eficiência. Este princípio já era reconhecido de forma implícita. O texto constitucional somente o oficializou. A principal consequência da introdução desse princípio no serviço público decorre da obrigatoriedade de prestar um serviço de forma eficiente, no que tange à população beneficiária deste e do órgão público que o presta.

No tocante à área de compras na Administração Pública, a realidade mudou nos últimos anos. A realização de compras e contratação de serviços em todos os órgãos da administração pública, necessários à execução de seus objetivos organizacionais, exige responsabilidade e uso adequado dos recursos públicos. Assim, a melhoria da eficiência dessa área pode levar a vantagens competitivas, não só pela redução de custos, mas também pela melhoria do desempenho do processo.

As instituições bem sucedidas enxergam a compra como uma atividade de importância estratégica considerável. O que se vê atualmente é que as instituições públicas vêm aumentando seus gastos com compras, o que amplia a responsabilidade do departamento de compras. Comprar de maneira eficiente, obtendo por meios éticos o melhor valor por centavo gasto, é um dos objetivos da equipe de aquisições de qualquer instituição (BAILY et al., 2013).

Corroborando com esta afirmativa, Batista e Maldonado (2008) avaliam também que o departamento de compras tem importância estratégica nas empresas públicas, representando um dos pilares da instituição, já que normalmente é o setor no qual se aplica a maior parte dos recursos orçamentários existentes. Os autores enfatizam ainda que a crescente busca pela maximização da qualidade, redução do custo, maior celeridade e flexibilidade das compras e contratações públicas, são consequências de uma constante preocupação dos gestores no uso eficiente dos recursos públicos, os quais representam uma parcela orçamentária importante. $\mathrm{O}$ seu apropriado gerenciamento é uma alternativa para a maximização da eficiência na 
utilização dos gastos públicos com a finalidade de melhorar o desempenho das instituições governamentais.

Costa (2000) avalia que alguns fatores são claramente diferenciáveis quando se compara compras públicas e privadas (Quadro 1):

Quadro 1 - Demonstrativo de diferenças entre o processo de compras públicas e privadas

\begin{tabular}{|c|c|c|}
\hline PARÂMIETRO & EMIPRESA PRIVADA & EMIPRESA PÚBLICA \\
\hline Seleção de fornecedores & $\begin{array}{l}\text { Centrado no fornecedor; } \\
\text { Possibilidade de parcerias; } \\
\text { Baseado no curso do ciclo de vida. }\end{array}$ & $\begin{array}{l}\text { Centrado no produto; } \\
\text { Cotação; } \\
\text { Impossibilidade de parceria; } \\
\text { Seleção baseada no preço. }\end{array}$ \\
\hline Avaliação dos fornecedores & $\begin{array}{l}\text { Facilidade de usar como critério de } \\
\text { avaliação os fornecimentos passados. }\end{array}$ & $\begin{array}{l}\text { Dificuldade de usar como critério de } \\
\text { avaliação os fornecimentos passados. }\end{array}$ \\
\hline Custo do pedido & $\begin{array}{l}\text { Pequenos; } \\
\text { Parcerias fazem tender à zero. }\end{array}$ & $\begin{array}{l}\text { Grandes; } \\
\text { Alto custo de vendas para o fornecedor. }\end{array}$ \\
\hline $\begin{array}{l}\text { Tamanho de lote de } \\
\text { compras }\end{array}$ & $\begin{array}{l}\text { Pequenos; } \\
\text { Entregas constantes. }\end{array}$ & $\begin{array}{l}\text { Grandes; } \\
\text { Entregas constantes somente com } \\
\text { Registro de Preços ou Padronização. }\end{array}$ \\
\hline Tempo de reposição & $\begin{array}{l}\text { Pequenos; } \\
\text { Tende a zero com os sistemas } \\
\text { eletrônicos. }\end{array}$ & $\begin{array}{l}\text { Grande; } \\
\text { Processo obedece à lógica cronológica; } \\
\text { Apelação jurídica dos participantes } \\
\text { pode estender o tempo. }\end{array}$ \\
\hline Preço e concorrência & $\begin{array}{l}\text { Centrado na qualidade, preço e tempo } \\
\text { de vida do produto. }\end{array}$ & Centrado no preço. \\
\hline Especificação do produto & $\begin{array}{l}\text { Especificação mais flexível; } \\
\text { Fornecedor pode participar do projeto } \\
\text { do produto; } \\
\text { Modificação na especificação com } \\
\text { curva de aprendizado de fabricação. }\end{array}$ & $\begin{array}{l}\text { Comprador fornece especificação } \\
\text { formal no início do processo de } \\
\text { compra, que tende, em regra, a ser } \\
\text { seguido rigorosamente. }\end{array}$ \\
\hline Inspeção de qualidade & $\begin{array}{l}\text { Pode ser no próprio fornecedor; } \\
\text { Qualidade garantida; } \\
\text { Inspeção de recebimento feita pelo } \\
\text { controle de qualidade. }\end{array}$ & $\begin{array}{l}\text { Dificuldade de trabalhar com qualidade } \\
\text { garantida; } \\
\text { Recebimento feito por uma comissão. }\end{array}$ \\
\hline Contratos & $\begin{array}{l}\text { Longa duração; } \\
\text { Flexível na especificação do produto; } \\
\text { Incorpora melhora técnica e } \\
\text { qualidade; } \\
\text { Modificações por negociação; } \\
\text { Troca de informação técnica durante } \\
\text { o contrato. }\end{array}$ & $\begin{array}{l}\text { Curta duração; } \\
\text { Na prática é mais rígido; } \\
\text { Especificação formal; } \\
\text { Dificuldade na troca de informação } \\
\text { técnica. }\end{array}$ \\
\hline Controle sobre a função & $\begin{array}{l}\text { Pequeno nível de formalismo; } \\
\text { Controle genérico sobre a função. }\end{array}$ & $\begin{array}{l}\text { Grande nível de formalismo; } \\
\text { Tudo deve ser documentado; } \\
\text { Controle sobre cada etapa do processo. }\end{array}$ \\
\hline
\end{tabular}

Fonte: Costa (2000) adaptado.

Para Batista e Maldonado (2008), existe um paralelismo grande entre a compra pública e a privada, pois ambas buscam o menor preço, com garantia de qualidade. Todavia, a compra pública requer procedimentos específicos para lhe dar eficácia, como a legislação; já na compra privada esses procedimentos são de livre escolha.

$\mathrm{Na}$ realidade, as empresas privadas compram materiais e/ou serviços de quem elas acham serem imprescindível ou conveniente, já na administração pública, com ressalvas de algumas hipóteses legais, as compras serão imprescindivelmente precedidas de licitação, 
tendo em vista o dinheiro e o interesse público que está em jogo. Por isso, os agentes públicos investidos na função de compradores públicos não podem agir livremente, mas sim, de acordo com a lei.

Nessa linha, o foco das administrações públicas é a transparência das relações e o emprego dos recursos para a satisfação da sociedade. Assim, percebe-se que na governabilidade de um país deverão ser preservados valores que garantam a eficiência e a eficácia na utilização dos bens públicos da sociedade. Para tanto, a administração pública vêse obrigada a utilizar um alto grau de formalismo nas suas relações para aquisições de bens e contratações de serviços (FARIA et al., 2010).

Nesse sentido, ao contrário dos compradores de empresas privadas, que compram materiais e serviços de quem ache mais conveniente, os compradores públicos apresentam procedimentos específicos para garantir eficiência, considerando os recursos financeiros e o interesse público. Na prática é montado um processo com vários documentos e informações apresentados em ordem cronológica como autorizações, pedidos, cotações, levantamentos, despachos, mapa de preços, documentos de habilitação, notas de empenho e pagamentos (BATISTA; MALDONADO, 2008).

Ressalta-se ainda que no início do ano é destinado um aporte financeiro para que os órgãos públicos possam funcionar e atingir a missão a que se propõem. Todavia, se ao final do ano esses órgãos públicos tiverem atingidos as metas propostas, e para tanto, não utilizaram todos os recursos financeiros a eles destinados, o saldo remanescente desses recursos retorna para os cofres do governo central. Observa-se que desta forma, ao invés de haver uma premiação por bons gastos, há uma punição, em tese, com a retirada dos recursos que não foram utilizados. E a tendência é que no ano seguinte, o aporte financeiro destinado a esses órgãos sejam supostamente menores do que no ano anterior, uma vez que o governo entende que não foram necessários tantos recursos para que os mesmos realizassem suas atividades.

A Lei de Licitações e Contratos Administrativos (Brasil, 1993) conceitua compra como toda "aquisição remunerada de bens para fornecimento de uma só vez ou parceladamente".

Em relação a esse conceito, faz-se necessário esclarecer o seguinte: a maioria dos processos licitatórios na administração pública é realizada com a finalidade de entrega do material a ser licitado de uma só vez. Nessa situação, o licitante ao participar do certame, se compromete a efetuar a entrega do material de uma só vez e no prazo estipulado no objeto convocatório. Para o fornecedor, esta situação se constitui em uma grande vantagem, pois irá 
arcar com os custos do transporte para a entrega do material em uma única vez. Todavia, para a Administração Pública se o consumo do material a ser entregue não for de imediato, o processo pode não ser vantajoso, pois o almoxarifado ficará com material em estoque por muito tempo, podendo inclusive, perder a sua validade. Ressalta-se ainda, que a administração teria de pagar todos os produtos de uma só vez.

No tocante ao fornecimento do material parcelado, com vistas ao princípio da economicidade, é interessante para a Administração Pública que o mesmo possa ser parcelado em quantas vezes for necessário, com a finalidade de sempre que possível aproveitar as peculiaridades do mercado (Brasil, 1993). Esta atitude pode proporcionar vantagens de imediato como: retardamento dos pagamentos, propiciando com isto a otimização dos recursos financeiros; melhor adequação da utilização do espaço físico do almoxarifado e, principalmente, evitar que os produtos adquiridos, tenham os seus prazos de validade vencidos em função de não serem requisitados para uso.

Do exposto, conclui-se que o fornecimento do material de forma parcelada é previsto na legislação em vigor, especialmente, nos casos de licitação por registro de preços, na qual a Administração não está obrigada a contratar o objeto na totalidade, mas sim, no momento em que achar necessário. Convém ressaltar que nessa modalidade, o procedimento pode gerar uma solicitação de realinhamento de preços por parte do fornecedor, o que é previsto também na legislação em vigor, entretanto, isto pode acarretar a falta de material momentânea, dada à burocracia que este procedimento envolve.

Baily et al. (2013, p. 16 e 31) avaliam que a "compra é vista pela organização bem sucedida de hoje como uma atividade de importância estratégica considerável”. Sua finalidade é prover com os materiais ou serviços necessários, em quantidades e qualidades certas, a preço adequado, e no momento certo. Desta forma, possibilita uma participação mais efetiva tanto da aquisição como do gerenciamento dos materiais utilizados em produtos e serviços cada vez mais adequados às necessidades do cliente final.

Observe-se que os elementos quantidade, qualidade, preço adequado, momento certo, são expressões da preocupação com o controle de custos e redução/eliminação de desperdícios. Nesse enfoque, uma boa compra pode ser definida como aquela que, ao conjugar tais elementos, apresenta a melhor relação de custo-benefício.

Nesse sentido, de acordo com Silva (2008), a área de compras assume responsabilidades mais amplas, indo além da tarefa específica de compras, isto é, de negociar preço, prazo e qualidade junto ao fornecedor, tornando-se interlocutora na disseminação das estratégias organizacionais em termos de produto, processo e suprimentos. Assim, as decisões 
de compras deixam de ser isoladas e passam a ficar cada vez mais agregadas às decisões de outras áreas (qualidade e finanças, por exemplo) que exercem um papel igualmente estratégico para a empresa.

Baily et al. (2013, p. 31) enfatizam também que a finalidade da compra é bastante criticada pela sua simplicidade e superficialidade. Para eles um bom objetivo deve ser mensurável de alguma forma, por isso sugerem uma definição mais ampla para os objetivos, a saber:

$\checkmark$ suprir a organização com um fluxo seguro de materiais e serviços para atender a suas necessidades;

$\checkmark$ assegurar continuidade de suprimento para manter relacionamentos efetivos com fontes existentes, desenvolvendo outras fontes de suprimentos alternativas, ou para atender a necessidades emergentes ou planejadas;

$\checkmark$ comprar eficiente e sabiamente, obtendo por meios éticos o melhor valor por centavo gasto;

$\checkmark$ administrar estoques para proporcionar o melhor serviço possível aos usuários e ao menor custo;

$\checkmark$ manter relacionamentos cooperativos sólidos com outros departamentos, fornecendo informações e aconselhamentos necessários para assegurar a operação eficaz de toda a organização;

$\checkmark$ desenvolver funcionários, políticas, procedimentos e organização para assegurar o alcance dos objetivos previstos.

Nesse enfoque, é de se questionar como a gestão de compras de uma organização pode ser considerada uma atividade de importância estratégica levando-se em consideração o cumprimento da legislação? Inicialmente, o questionamento nos remete a ideia de que as organizações precisam realizar um planejamento de compras que requer o desenvolvimento de estruturas que permitam a ocorrência desse processo.

Nessa linha, os autores Baily et al. (2013, p. 38) avaliam que uma operação de compra estratégica proativa pode dar a organização uma vantagem competitiva ao reduzir o desperdício na cadeia de valor. As compras proativas agregam valor, evitam materiais defeituosos e evita-se o desperdício com o excesso de estoque proporcionando assim, racionalidade, celeridade e economicidade, aos processos de compras da organização.

Para tanto, é necessário que a administração elabore um planejamento de compras quantitativa e qualitativamente, de tal forma que os procedimentos de compras previstos em lei, não sejam comprometidos pelas normas fixadas pela Administração. Assim, o controle do 
fluxo de materiais e serviços dentro das empresas proporciona que eles cheguem ao local correto, no momento exato, na devida quantidade, vindos da fonte certa e com as melhores condições de qualidade e preço.

Convém ressaltar ainda que um processo de compras envolve atividades além daquelas diretamente relacionadas com a movimentação e armazenagem de materiais. Nesse enfoque, um ponto crucial que interessa a logística de compras é a colocação inicial dos pedidos de compras pelos setores interessados. O documento de compra especifica as quantidades e o detalhamento do material a ser adquirido. É este documento que inicia o fluxo de materiais no canal de suprimento, pois estabelece o volume do material a ser movimentado e armazenado no sistema logístico em determinado instante e, portanto, deve estar o mais correto possível.

A definição do método de compra é importante para se estabelecer as condutas que as firmas terão em relação à formação de seus preços. Logo, a organização deve sempre buscar a negociação de forma a baixar os preços. Embora isto possa fazer com que alguns potenciais fornecedores optem por ficar fora do mercado, tal atitude em geral contribui bastante para a redução das cotações. Exemplo disto são as reduções de preços obtidas no governo federal quando este utiliza a modalidade de licitação por pregão, que se constitui em um leilão reverso. Nessa ótica, a área de compras desempenha um papel importante na realização dos objetivos estratégicos da instituição, devido à sua capacidade de afetar a qualidade e entrega de produtos ou serviços essenciais que serão utilizados nas pesquisas científicas.

\subsection{Teoria dos Leilões}

Segundo a literatura, leilão é um mercado no qual cada interessado faz um lance na intenção de adquirir o bem à venda. Os bens leiloados são vendidos em lote, que pode ser um conjunto de bens ou apenas uma unidade do mesmo. Aquele que dispõe o bem para a venda é denominado arrematante, já aquele que coordena os lances do leilão e recebe as ofertas é denominado de leiloeiro. Na maioria dos casos, o leiloeiro tem função pública, portanto, o lance tem o valor de um contrato firmado perante a uma autoridade, impedindo, assim, lances especulativos. Os leilões ocorrem tanto presenciais, no qual cada participante levanta a própria mão para o lance, quanto virtual, nos quais os lances, em alguns casos, podem ser programados.

De acordo com Silva (2007), a literatura sobre leilões demonstra através dos diversos modelos propostos, que o número de participantes dos leilões, afeta significativamente, a receita dos leilões. Desta forma, admitindo-se uma maior competição entre os participantes do 
mercado (traduzindo-se em um maior número de licitantes), haveria uma concorrência mais acirrada pelo objeto leiloado, impossibilitando, assim, posições monopolísticas, as quais tendem a promover a concentração do mercado e a elevar as taxas praticadas nos leilões.

Bertolini e Cottarelli apud Durães (1997) admitem que, aumentando-se o número de licitantes, aumenta, concomitantemente, a probabilidade de que um licitante com maiores avaliações participe dos leilões e, desta forma, uma maior participação de licitantes produzirá provavelmente, maiores lucros para o leiloeiro. Contudo, advertem que um maior número de licitantes também reforça a praga do vencedor, pois em leilões com um maior número de licitantes, o lance ganhador provavelmente se afasta do consenso de mercado, fato este que, em geral, não é observado quando há poucos licitantes.

Carter e Stevens (2007) citam que embora vários estudos tenham sugerido que leilões reversos podem levar a redução de preços para os compradores, eles também têm indicado que os leilões reversos podem resultar em aumento da percepção de oportunismo por parte do comprador. Para eles, existem várias evidências na literatura que colaboram com a ideia de que o número de licitantes é relacionado positivamente ao preço praticado em um leilão. Todavia, os autores acreditam que esta relação não seja linear.

Sob esta ótica, Cox et al. apud Carter e Stevens (2007), perceberam que os preços de oferta eram significativamente mais altos em leilões com quatro, cinco, seis e nove participantes que em leilões com três participantes. Carter s Stevens (2007), citam também que Dyer et al. (1989) compararam tamanhos de mercado de três e seis concorrentes, e encontraram ofertas mais competitivas nos mercados de maior porte. Continuando, os autores afirmam que Cox et al. (1988) não encontraram diferenças significativas nos preços de oferta quando existiam quatro, cinco, ou seis concorrentes, porém no caso de três concorrentes os preços foram significativamente menores nos leilões a termo do que no caso de quatro, cinco ou seis concorrentes. Finalizando, os autores ressaltam ainda que, usualmente, o número de licitantes é tomado como exógeno com respeito ao formato do leilão e, nesse sentido, há poucas informações sobre os incentivos necessários à participação adequada dos licitantes nos diferentes formatos de leilão.

Para Menezes et al. (2007), os leilões são instituições seculares utilizadas nas relações comerciais entre indivíduos e organizações, os quais proveem maior flexibilidade aos processos de determinação de preços e alocação de bens, aumentando o espaço para negociações entre compradores e vendedores. Na Internet, têm sido empregados, de maneira crescente, em atividades de comércio eletrônico C2C (consumers to consumers) e B2C (busenesses to consumers), em sua maioria, através da modalidade de leilão reverso. O autor 
afirma, no entanto, que seu aspecto unidimensional reduz as negociações à variável preço, produzindo, muitas vezes, resultados aquém do desejado.

Para Faria et al. (2010), os leilões são mecanismos importantes nos contratos públicos, contudo, não são a panaceia para todos os problemas, principalmente de preços. Existem fatores críticos que devem ser observados para se ter maior eficácia na busca de melhores preços de aquisição.

Wolfstetter apud Silva (2007) afirma que a eficiência do leilão dependerá da existência de mecanismos e regras específicas que aumentem sua atratividade e reduza as possibilidades de conchavos, competição predatória e outras formas de poder de mercado.

No que se refere às propriedades principais dos leilões, é necessário registrar que, em condições bastante razoáveis (sinais dos valores dos compradores provêm da mesma função de distribuição de probabilidades), qualquer leilão padrão resulta na venda do objeto para o comprador com o maior sinal. Em outras palavras, os mecanismos de leilão geralmente resultam na aquisição do objeto por aquele indivíduo que mais atribui valor a ele ou que é mais eficiente (caso de empresas ou concessões, por exemplo), e usualmente, os que atribuem maior valor ao objeto ou os mais eficientes, são aqueles que estão dispostos a fazer (e fazem) lances maiores, resultando em uma receita maior da venda do objeto (SILVA, 2007).

Para Durães (1997), as regras institucionais dos principais tipos de leilões são de fundamental importância, uma vez que influenciam a formulação e estratégias das propostas dos licitantes, bem como determinam a eficiência da alocação dos bens leiloados.

Segundo a literatura, a Teoria dos Leilões estabelece quatro tipos básicos de leilões competitivos utilizados para a venda de bens: leilão inglês ou de preço ascendente; leilão alemão ou de preço descendente; leilão discriminatório ou leilão de primeiro preço e leilão de segundo preço.

De acordo com Mattos apud Silva (2007), existe ainda o leilão híbrido anglo-holandês de dois estágios: leilão ascendente em um primeiro estágio e leilão selado (quando sobram dois compradores, por exemplo) em um segundo estágio com um só round. Silva (2007) cita ainda, que de acordo com Klemperer (2004), o leilão híbrido frequentemente tem melhor desempenho que as formas puras dessas duas modalidades, capturando o que há de melhor em cada uma delas, reduzindo problemas de maldição do vencedor, cartelização, dentre outros, sendo o mais recomendado quando o pior problema é a "maldição do vencedor". Para o autor, este formato foi adotado no Brasil como uma modalidade especial de licitação denominada "Pregão". 
Para Nascimento (2012), este tipo de leilão ficou conhecido por ter sido utilizado na Holanda para a comercialização de flores. O seu formato se processa de forma aberta, a exemplo do leilão inglês, porém com característica oposta uma vez que progressivamente, o preço vai sendo reduzido até que um concorrente reivindique o item ao preço corrente.

Para o autor, quando unidades múltiplas são leiloadas o número de licitantes dispostos a arrematar o bem (ao último preço proposto), torna-se maior à medida que o preço declina. Desta forma, o processo continua até que a demanda total se iguale à quantidade oferecida. Assim, os bens são progressivamente premiados aos licitantes individuais, os quais podem comprar qualquer fração do estoque à venda ao preço corrente à medida que o preço cai. As figuras 2 e 3 demonstram o funcionamento do leilão holandês, para bem único e bem múltiplo, respectivamente:

Figura 2 - Leilão holandês - bem único

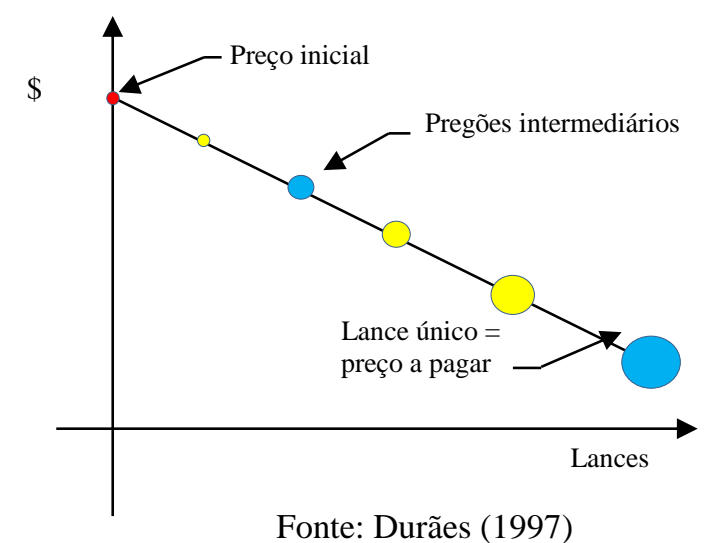

Fonte: Durães (1997)

Figura 3 - Leilão holandês - bem múltiplo

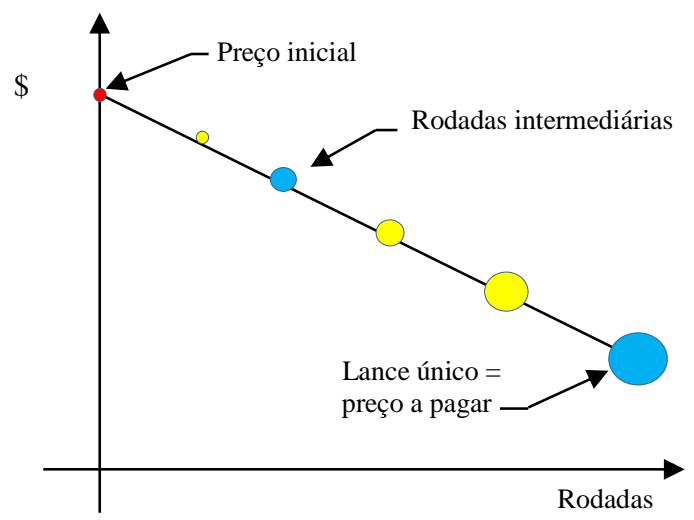

Fonte: Durães (1997) 
Com regras simples e bem definidas, os leilões promovem maior flexibilidade à tarefa de determinação de preços, na medida em que os preços são definidos unilateralmente pelo vendedor, não cabendo espaço para negociação entre as partes, configurando uma situação do tipo "pegar ou largar", na qual os compradores se viam impedidos de fazer contrapropostas. Nos leilões reversos, a organização compradora interage com diversas organizações fornecedoras. Para tal, informam o preço máximo que admitem pagar por um determinado bem ou serviço e, em seguida, recebem lances decrescentes de fornecedores interessados. No que tange às compras públicas brasileiras, o instrumento de Pregão Eletrônico implementa um mecanismo de leilão reverso baseado no atributo preço, possibilitando a disputa por contratos, mediante a submissão de lances decrescentes, por fornecedores, através do próprio site do Portal Comprasnet (MENEZES et al., 2007).

Os autores afirmam ainda que considerando um leilão reverso $L_{R}$, com preço máximo $p_{\max }$ e decremento mínimo $\delta_{L_{R}}$, previamente definidos pela organização compradora,

só poderão ser aceitos lances $b_{i} \leq p_{\max } \delta_{L_{R}}, \forall \mathrm{i}=1 \ldots n$ participantes. A cada lance aceito, o novo preço máximo $p_{\max }-b_{i}$ é calculado e novo round se inicia, com a submissão de novos lances, pelos participantes. O leilão é encerrado quando não são observadas novas ofertas durante um intervalo de tempo preestabelecido, ou quando o prazo estipulado para a sua realização expira. Nesses casos, o direito de comercializar o bem ou serviço é assegurado ao fornecedor que submeteu o lance mais baixo, $b_{i}=p_{\max }$.

Para Durães apud Silva (2007), a análise teórica, comparando os leilões com base na receita esperada, eficiência alocativa, custo de preparação dos lances e vulnerabilidade às fraudes, representa, basicamente, o cerne da Teoria. A autora ressalta ainda que no caso da administração pública, a orientação de maximização se inverte para o menor custo, dados os padrões, qualidade e condicionalidade exigidas.

Assim, Faria et al. (2010) apontam que não há uma tipologia para leilões que seja universalmente aceita. Para os autores, em verdade, existem inúmeras formas híbridas que são derivações de tipos clássicos que, em sua grande maioria, têm reduzida importância no que tange aos seus aspectos práticos e teóricos.

\subsection{Custos de Transação sob a ótica da Nova Economia Institucional}

A Teoria dos Custos de Transação, principal teoria da Nova Economia Institucional, foi desenvolvida por Wiliamson (1975, 1981 e 1985) a partir do trabalho pioneiro de Coase (1937). Essa abordagem sugere que os formatos organizacionais ou estruturas de governança 
(firma, mercado ou redes, por exemplo) são resultado da busca de minimização dos custos de transação por parte dos agentes econômicos. A teoria dos custos de transação tem como pressupostos comportamentais básicos, a racionalidade limitada e o oportunismo, ambos, presentes nas ações dos agentes econômicos, os quais a respeito de sua competência cognitiva e de suas motivações provocam o surgimento de custos de transações (BREITENBACH et al., 2009).

Enquanto a teoria não ortodoxa explicava o mercado a partir do mecanismo de preços no qual a firma era uma coleção de transformações tecnológicas (função produção - input processamento - output), Coase concluiu que a firma fazia muito mais que transformar insumos em produtos, uma vez que coordenava as ações dos agentes econômicos. Logo, tanto a firma como o mercado concorriam entre si na função de coordenar a atividade econômica. $\mathrm{O}$ exercício dessa função implicava num custo proveniente da coleta de informações, da elaboração, da redação, da negociação e do estabelecimento de um contrato que representasse as transações (SANTOS, 2007).

Reconhecer que o ato de produzir se desdobra em compras e em vendas que acarretam ônus, significa considerar a existência dos custos de transação que não podem ser negligenciados em prol dos custos de produção. Logo, é fundamental ir além da função produção, ou seja, considerar outros custos que não sejam somente os associados à transformação e que também constituem um elemento importante nas decisões dos agentes econômicos, auxiliando na determinação da forma pela qual são alocados os recursos na economia (SANTOS, 2007).

Faria et al. (2010) afirmam que os agentes econômicos tem racionalidade limitada e são capazes de comportamento oportunista. Especificidades dos ativos unidas à racionalidade limitada, oportunismo e incerteza, causam tensão contratual e organizacional. Segundo os autores, esse aspecto foi abordado por Wiliamson et al. (1990), que desenvolveram um modelo a partir da incorporação dos chamados "atributos das transações" e dos "pressupostos comportamentais" ao conceito de custos de transação. Para os autores, em linhas gerais, afirma-se que tais custos decorrem destes dois condicionantes. Os pressupostos comportamentais são a racionalidade limitada e o oportunismo. Por sua vez, os principais atributos de uma transação são o grau de especificidade do ativo, a frequência e a incerteza, sendo a especificidade o atributo mais relevante na determinação dos custos de transação. 


\subsubsection{Racionalidade limitada}

De acordo com Breitenbach et al. (2009), a existência da racionalidade limitada provoca, consequentemente, a incapacidade de coletar e processar todas as informações necessárias à elaboração de contratos completos. Se os agentes tivessem a capacidade de prever os eventos futuros, os contratos seriam desenvolvidos sempre perfeitamente. Isso demonstra que essas a racionalidade limitada é uma das implicações que proporciona condições necessárias ao surgimento de custos de transação. A ausência de informações que possibilite a especificação adequada do objeto a ser licitado, pode acarretar em custos de transação com implicações oportunística. Dessa maneira, os fornecedores poderão aproveitarse desta incompletude para cotar produtos de pior qualidade ou que não atendam às necessidades do comprador (FARIA et. al., 2010).

Para Júnior e Machado apud Faria et al. (2010), os agentes econômicos procuram agir racionalmente no momento em que tomam uma determinada decisão. No entanto, possuem uma limitação cognitiva que os impede de antever algo que possa acontecer no futuro. Segundo Araújo e Jesus (2013), tal afirmação é compartilhada por Wiliamson (1985), para quem contratos completos são impossíveis. Isso se deve à assimetria de informações envolvida em transações, ou seja, quando um agente possui informações não disponíveis para os outros agentes participantes do oportunismo pré-contratual, que surge decorrente do fato de alguns agentes econômicos deterem informações privilegiadas antes de optarem pela transação.

Santos (2007) avalia que a racionalidade limitada é resultante da incapacidade do indivíduo em desenvolver plenamente sua capacidade cognitiva em todos os momentos, fator que limita sua percepção da realidade. Para Valle e Filho apud Faria et al. (2010), a racionalidade limitada deriva da convicção de que os agentes econômicos, embora tentem pautar suas ações em moldes estritamente racionais, só conseguem fazê-lo de modo parcial, dada a assimetria informacional e a restrita capacidade de processamento das informações.

Nesse contexto, Faria et al. (2010) avaliam que ao assumir como verdadeiro o pressuposto da racionalidade limitada do ser humano, a qualidade das informações passa verdadeiramente a ser uma variável chave para a tomada de decisões, sendo esta, talvez, uma das grandes contribuições teóricas da Nova Economia Institucional. 


\subsubsection{Oportunismo}

Santos (2007) avalia o oportunismo como sendo sinônimo de um comportamento aético que eleva os custos de transação, devido ao fato dos agentes econômicos visarem aumentar benefícios próprios em detrimento dos demais, descumprindo acordos ou buscando brechas nos mesmos para a promoção do seu auto interesse. Diniz et al. (2004) acrescentam que esse comportamento aético, pode advir da incompletude dos contratos gerando perdas para uma das partes envolvidas. Todavia, os autores avaliam que não se pode afirmar que todos os agentes agem de forma oportunística o tempo todo, porém, não se pode ignorar que estes venham a agir oportunisticamente em algum momento, com a finalidade de buscar apropriar-se das quase rendas advindas da existência de ativos específicos.

Nessa ótica, Alves e Staduto apud Faria et al. (2013), opinam que dada a oportunidade, o tomador de decisão pode, inescrupulosamente, procurar atender seus próprios interesses, e há a dificuldade de conhecer "a priori" quem é de confiança e quem não é, podendo ser definido como problema de assimetria informacional. Segundo Valle et al. apud Faria et al. (2013), desta forma, depreende-se que o oportunismo está vinculado à noção de que os agentes econômicos buscarão sempre obter o maior ganho possível no decorrer das transações, ainda que isso implique perdas aos demais.

O comportamento oportunista pode ocorrer tanto antes da efetivação dos acordos, conhecido como oportunismo ex-ante, quanto após a execução dos mesmos, denominado oportunismo ex-post. Nesse sentido, os custos de transação ex-ante referem-se a dispêndios para negociar os termos do contrato e estabelecer salvaguardas, ou seja, são custos preventivos (LAUREANO, 2005).

Diante disso, ambos os pressupostos, racionalidade e oportunismo, indicam um mesmo sentido de fundamentação teórica: a impossibilidade de confecção de contratos completos. Esta máxima resulta na necessidade de contínuas negociações pós-transação que terminam por tornar a questão da flexibilidade como um elemento importante a ser considerado quando da confecção de estruturas de governanças nos arranjos interorganizacionais. Os agentes econômicos, devido ao oportunismo e a racionalidade limitada intrínseca aos indivíduos (mentira, artimanha, trapaça, conluio e até violação de contrao), desenvolvem estruturas de governança para reduzir os custos envolvidos em uma determinada transação, além de garantir a continuidade do contrato e a redução dos custos de transação, de forma que ações oportunistas sejam afastadas (JUNIOR e MACHADO apud FARIA et al., 2013). 
Para Zylbersztajn e Neves (2000, p. 31-32), existem três razões explicativas que fazem com que os agentes não quebrem os contratos, mesmo quando tentados pela existência destas quase rendas: a reputação, as garantias legais e os princípios éticos.

No que diz respeito à reputação, o indivíduo não rompe o contrato, em situação oportunística, por saber que se o fizer, terá interrompido o fluxo de renda futura. No caso das garantias legais, os agentes econômicos terão um desestímulo para a quebra contratual oportunística, pelo fato de existir mecanismos punitivos instituídos pela sociedade, através da legislação associada a um sistema capaz de identificar, julgar e punir os agentes que rompem os contratos. Quanto aos princípios éticos, estes devem ser entendidos como uma construção humana que tem como uma de suas finalidades a restrição ao comportamento oportunista. É uma restrição informal que disciplina o comportamento daqueles que exercem o jogo social (DINIZ et al., 2004).

Nesse contexto, Faria et al. apud Tridapalli e Beronelli (2015) afirmam que no caso das licitações, os agentes econômicos envolvidos nos processos licitatórios, poderão agir com oportunismo quando órgãos públicos não especificarem de forma completa o produto licitado. Desta forma, poderão se aproveitar desta incompletude para cotar produtos de pior qualidade ou que não atendam as necessidades do comprador.

Para Porter e Zona apud Tridapalli e Beronelli (2015), existem armadilhas nas compras por leilão que, dependendo das circunstâncias, podem torná-las muito vulneráveis à colusão e impedir a entrada de outros concorrentes. Oura et al. (2012) avaliam que o uso isolado do leilão reverso parece não ser suficiente para coibir ações de oportunismo que, se não podem ser caracterizadas diretamente como fraudes premeditadas, beiram perigosamente esses princípios e, para esses fins, o sistema não apresenta sinais expressivos de eficácia.

Desta forma, Tridapalli e Beronelli (2015) afirmam que os benefícios dos leilões podem ser reduzidos se não forem eliminados os fatores que permitem o conluio do mercado. Para os autores, se isto não for combatido, podem afastar licitantes, permitindo a formação de monopólio para manipulação de preços.

Para Oura et al. (2012), para o combate ao oportunismo dos licitantes, falta um sistema de inteligência de informações de uso simultâneo ao pregão eletrônico, com a finalidade de possibilitar a coleta de informações permanentes no mercado, e não esporádica, diretamente de potenciais licitantes. Para os autores, esse sistema poderia ser uma solução mais eficaz contra o oportunismo de licitantes, pois estaria dando à área demandante as informações preliminares necessárias, de forma impessoal e desligada de possíveis interesses futuros, permitindo-lhes durante as licitações, decisões mais eficazes. 
Nesse sentido, a existência de um corpo técnico competente e sistematicamente treinado no uso das tecnologias disponíveis e no comportamento do mercado, pode ser um fator crítico para a maior eficácia das compras públicas.

\subsubsection{Incerteza}

Para Santos (2007), a incerteza é decorrente da incapacidade em se prever integralmente as atitudes dos agentes econômicos e as mudanças no ambiente, de forma a não permitir que se calculem precisamente os acontecimentos presentes e futuros. A autora observa ainda que a incerteza evidencia a instabilidade do equilíbrio de mercado.

De acordo com Breitenbach et al. (2009), a incerteza é uma propriedades das transações que exerce influência sobre as características das organizações. Para os autores, na incerteza não existem bases válidas que permitam calculá-la ou antecipá-la, pois não existem regras que façam o passado se repetir no futuro. Esta questão dificulta agir com racionalidade frente ao futuro, pois os agentes econômicos formam expectativas de longo prazo subordinados à vigência de um estado de confiança que é subjetivo e volátil.

No campo organizacional, a fonte fundamental de incerteza decorre exatamente do suposto de racionalidade limitada dos agentes. Não fosse esse aspecto, as estruturas de governança seriam capazes de se ajustar às alterações havidas no ambiente. Para muitos autores este é o grande problema das organizações econômicas: a constante necessidade de adaptação às alterações de natureza institucional que ocorrem no ambiente dos negócios (ARBAGE apud FARIA et al., 2010).

\subsubsection{Especificidade dos ativos}

Segundo Santos (2007), a especificidade de ativos significa a impossibilidade de realocar ou reutilizar os gastos em outras atividades sem que ocorram perdas de valor em sua nova modalidade de uso. Assim, tem como resultado o estabelecimento de uma relação de dependência entre as partes, com desdobramentos sobre o processo de barganha entre estas.

Para Júnior e Machado apud Faria et al. (2010), a especificidade de ativos coloca em risco o investimento feito, caso a transação não seja realizada pelo fato de o uso alternativo desse investimento ser baixo ou não existir.

No entanto, para Diniz et al. apud Faria et al. (2010), o rompimento do contrato pode não ser interessante quando a alta especificidade está muito mais definida para uma das partes. Para os autores, a parte mais afetada neste caso se salvaguardará de uma eventual 
ruptura contratual pela parte não afetada. Afirmam ainda que outra situação acontece quando todos os envolvidos fazem investimentos específicos, ou seja, no caso de dependência bilateral. Desta forma, os esforços serão concentrados para que o contrato continue indefinidamente.

Nesse sentido, Breitenbach et al. (2009), afirmam que quanto menor a especificidade dos ativos, menor a incerteza e menor a frequência das transações, menores serão os custos associados à utilização do mercado como forma organizacional que coordene as interações mercantis entre os agentes econômicos. Nestes casos, a transação se refere à simples transferência da propriedade de um bem ou serviço em troca de uma determinada quantidade de moeda, acompanhada de uma negociação prévia do preço e das condições de pagamento.

\subsection{Licitação: modalidades, tipos e características.}

A palavra licitação significa o método adotado pela Administração Pública com o objetivo de selecionar a contratação de serviços, obras e aquisição, locação ou alienação de bens. A proposta mais vantajosa, isto é, aquela que melhor atenda ao interesse público, não somente no preço como também na qualidade do serviço prestado, será a vencedora para fornecer tais serviços ou produtos.

Por outro lado, licitação pode ser definida através de várias denotações. A maioria está ligada à ideia de oferecer, arrematar, fazer preço sobre a coisa, disputar ou concorrer. Di Pietro (2003, p. 299) define licitação como sendo:

O procedimento administrativo pelo qual um ente público, no exercício da função administrativa, abre a todos os interessados, que se sujeitem às condições fixadas no instrumento convocatório, a possibilidade de formularem propostas dentre as quais selecionará e aceitará a mais conveniente para celebração de contrato.

Para Justen Filho (2008):

A licitação destina-se a selecionar a proposta mais vantajosa para a Administração
Pública (com observância do princípio da isonomia). A vantagem caracteriza-se
como a adequação e satisfação do interesse coletivo por via da execução do contrato.
A maior vantagem apresenta-se quando a Administração assumir o dever de realizar
a prestação menos onerosa e o particular se obrigar a realizar a melhor e mais
completa prestação. Configura-se, portanto, uma relação custo-benefício.

Assim, os contratos administrativos devem ser precedidos de formalidades que assegurem moralidade administrativa e igualdade aos interessados em contratar. Para tanto, ordenaram-se as regras e efetivaram-se os procedimentos da licitação pública para selecionar, de maneira legítima, a proposta mais vantajosa ao interesse público (AMARAL, 2002). 
No Brasil, a Lei de licitações estabelece cinco modalidades licitatórias: concorrência, tomada de preços, convite, concurso e leilão, as quais de maneira ampla são definidas de acordo com o objeto a ser contratado e/ou conforme o valor de referência. Dentre elas as que mais se destacam são: a concorrência, a tomada de preços, o convite e o pregão.

A concorrência é uma modalidade da qual podem participar quaisquer interessados que na fase de habilitação preliminar comprovem possuir requisitos mínimos de qualificação exigidos no edital para execução do objeto da licitação. Esta modalidade deve ser utilizada para: Obras e serviços de engenharia acima de R \$ 1.500.000,00 (Hum milhão e quinhentos mil reais); Compras e serviços acima de $\mathrm{R} \$$ 650.000,00 (Seiscentos e cinquenta mil reais) e Compras e alienações de bens imóveis da Administração (exceto os adquiridos por procedimentos judiciais ou dação em pagamento). É importante ressaltar que acima de R\$ 150.000.000,00 (Cento e cinquenta milhões de reais), é obrigatória a realização de audiência pública, 15 dias antes da publicação do edital.

A ampla publicidade nessa modalidade prevê o envio dos editais de aviso ao Diário Oficial da União, aos jornais locais e até aos regionais, com prazos mínimos de 45 e 30 dias, anteriores ao prazo marcado para entrega das propostas, para os tipos técnica e preço e menor preço, respectivamente.

Caracteriza-se a seu turno, pela existência de uma fase inicial no procedimento da concorrência, denominada habilitação, em que quaisquer interessados que demonstrem o preenchimento dos requisitos de qualificação previstos em lei, poderão apresentar propostas, as quais serão examinadas para se determinar a idoneidade necessária para participação da fase seguinte do certame. As empresas desclassificadas nessa fase poderão interpor recursos e a etapa seguinte somente poderão ocorrer depois de encerrados os prazos dos pedidos de consideração, bem como exaradas as respectivas respostas aos questionamentos levantados quanto à habilitação.

Caso todas as empresas interessadas sejam desclassificadas nessa fase de habilitação, a Administração poderá abrir prazo adicional para apresentação de nova documentação que se coadune ao requerido pela licitação. Após o término da fase de habilitação, as empresas terão abertas suas propostas comerciais, que podem ser do tipo menor preço, classificados por ordem crescente, ou, técnica e preço. Neste último caso, o edital deverá ter estabelecido peso e pontuação para julgamento das vantagens técnicas oferecidas pelos participantes, bem como o mínimo aceito pela Administração para cada item a ser avaliado, as concorrentes aptas somarão aos pontos obtidos nessa fase àqueles correspondentes ao oferecimento do menor preço. 
As propostas comerciais poderão ser desclassificadas caso não atendam às exigências contidas no edital, ou, caso seus valores estejam acima daqueles estabelecidos pela Administração, ou, ainda, em contraponto, caso sejam inexequíveis, assim considerados aqueles que não venham a ter demonstrada sua viabilidade de execução. Também nessa fase, as empresas desqualificadas poderão recorrer e suspenderão os procedimentos até o resultado final da competição.

Finalizada a fase de desclassificação das propostas inabilitadas, prosseguir-se-á a classificação final, a qual ocorrerá de acordo com o tipo de licitação adotada. Assim, em licitação do tipo menor preço, as propostas que atendam aos requisitos do edital e que não apresentem preços inexequíveis ou exorbitantes serão classificadas por ordem crescente de seus preços. A primeira colocada será a de menor preço, a segunda colocada a que tenha apresentado o segundo menor preço, e assim sucessivamente. Para a licitação de Concorrência do tipo técnica e preço, será consagrada vencedora a empresa que obtiver a maior pontuação dentro dos critérios e pesos estabelecidos no edital do certame.

A tomada de preços, segundo Meirelles (1998, p. 278) é a modalidade realizada entre interessados convocados com antecedência mínima prevista em lei, por aviso publicado na imprensa oficial e jornal particular, contendo as informações para o certame. Acrescenta ainda o autor que é característico da tomada de preço a existência de habilitação prévia dos licitantes através de registro cadastral, sendo que a habilitação preliminar consiste na verificação dos dados constantes dos certificados de registro dos interessados, e quando for necessário, na verificação sobre real capacidade operativa e financeira dos licitantes. A Tomada de Preços é utilizada para obras e serviços de engenharia até R \$1.500.000,00 (Hum milhão e quinhentos mil reais) e Compras e serviços até $\mathrm{R} \$$ 650.000,00 (Seiscentos e cinquenta mil reais). Nessa modalidade de licitação, seus prazos serão reduzidos para 30 e 15 dias, nos casos de licitação tipo técnica e menor preço, respectivamente.

Da mesma forma como na concorrência, na tomada de preços também é possível haver abertura de novo prazo para entrega de propostas caso todas as interessadas sejam desclassificadas do certame. Além disso, os recursos podem ser interpostos em qualquer momento em que as concorrentes acreditem terem sido prejudicadas, suspendendo-se o certame até a resposta definitiva para o pleito.

Por fim, a licitação por convite, que é a mais simples delas. Para Cretella Júnior (1999, p. 163), é a modalidade de licitação entre interessados do mesmo ramo do objeto licitado, em número mínimo de três, convidados pela instituição para participação do certame. Para tal, Braz (1995, p. 77) cita que a Administração deve considerar a idoneidade dos 
licitantes e o seu próprio interesse e afirma, ainda, que a carta-convite precisa de publicidade, sendo que esta fica submetida ao princípio da isonomia e da moralidade pública. O Convite é permitido para obras e serviços de engenharia até $\mathrm{R} \$$ 150.000,00 (Cento e cinquenta mil reais) e para Compras e Serviços até R \$ 80.000,00 (Oitenta mil reais).

O convite adota um procedimento de forma bastante simplificada. A Administração escolhe pelo menos três possíveis interessados no objeto que será licitado e dirigi-lhes CartaConvite convocando-os a apresentarem suas propostas. As regras inerentes a sua divulgação são mais simples. Nessa modalidade, a lei apenas impõe a obrigação de que promova a afixação da carta no quadro de avisos da repartição. O prazo para apresentação das propostas será, de no mínimo cinco dias após o recebimento da correspondência pelos interessados.

A documentação dos convidados já está toda em poder da Administração que os selecionou par participar do certame. Sendo assim, resta-lhes somente trazer o envelope com as propostas comerciais para a escolha do menor preço. Nessa modalidade, os recursos também podem ser interpostos a qualquer momento e suspendem a licitação até que se tenham um veredito final.

Nas modalidades supracitadas, as propostas comerciais são entregues em envelopes lacrados, devidamente identificados, por meio de papel timbrado, contendo todas as informações que identifiquem a licitação a que participam do objeto, as condições de prestação de serviços ou fornecimento de bens e o valor proposto, tanto numérico quanto por extenso, tudo livre de qualquer rasura, sob pena de imediata e irrefutável desclassificado (FURTADO, 2001).

É importante frisar que a divulgação antecipada da realização dos procedimentos licitatórios é obrigatória, com vistas a atender o princípio da publicidade. $\mathrm{O}$ aviso contendo o resumo do edital deverá descrever as principais informações relativas à licitação, possibilitando a identificação do objeto licitado, do órgão contratante e das datas e prazos previstos.

Face ao exposto, observa-se também que nas modalidades supracitadas, há direito de interposição de recursos, ampla defesa e contraditória em todas as fases do certame, conferindo-lhes prazos que, na maioria das vezes, suspendem o processo licitatório.

Como já ressaltado, em regra, a Administração Pública se utiliza de procedimento licitatório para contratação de obras, bens e serviços. Contudo, a lei estabelece exceções, casos em que a licitação poderá ser dispensa ou inexigível, podendo assim o órgão público contratar de forma direta, uma vez cumpridas as formalidades previstas legalmente. 
Ambas deverão ser necessariamente justificadas. Conforme o caso, os respectivos processos deverão ser instruídos com elementos que demonstrem a caracterização da situação atípica que a justifique, além dos imperativos de que os preços praticados sejam razoáveis e condizentes com aqueles de mercado (COUTO, RAMOS e GRAZZIOTIN, 2009).

Nos casos de dispensa de licitação, a Administração Pública deverá levar em conta o custo-benefício entre licitar ou dispensar. A doutrina divide a dispensa em duas hipóteses: licitação dispensada e licitação dispensável. O art. 17 da Lei de Licitações estabelece os casos em que a licitação é dispensada, em que a Administração Pública é obrigada a promover a dispensa, não havendo, portanto, margem de liberdade por parte do agente público. Já a licitação dispensável possibilita o poder discricionário do gestor em licitar ou não (BRASIL, 1993). O art. 24 arrola as situações passíveis de licitação dispensável que podem ser em razão do valor, em razão da situação, em razão do objeto ou em razão da pessoa.

É inexigível a licitação quando houver inviabilidade de competição, como disciplina o art. 25 da Lei de Licitações. Como exemplo de situações de inexigibilidade, o artigo aponta:

$\checkmark$ Contratação de fornecedor exclusivo;

$\checkmark$ Contratação de profissionais de notória especialização;

$\checkmark$ Contratação de artistas consagrados pela crítica.

Destaca-se ainda que de acordo com a Lei existem quatro tipos de licitação, quais sejam:

$\checkmark$ Menor Preço: Nesse caso, o que vale é o menor preço. Em algumas licitações, o menor preço está limitado ao que pode ser exequível. É o caso de obras públicas de grande porte;

$\checkmark$ Melhor Técnica: Em alguns casos, principalmente quando o trabalho é complexo, o órgão público pode basear-se nos parâmetros técnicos para determinar o vencedor;

$\checkmark$ Menor Preço e Melhor Técnica: Nesse caso, os dois parâmetros são importantes. Assim, no próprio edital de licitação deve estar claro o peso que cada um dos parâmetros (preço e qualidade técnica) deve ter para que se possa fazer uma média ponderada.

$\checkmark$ Maior lance ou oferta: Nesse caso, prevalece a proposta ou lance com o maior preço, sendo adotada nos casos de alienação de bens ou concessão de direito real de uso.

Analisando-se os conceitos de licitação e as especificidades de suas modalidades, pode-se inferir que a mesma compreende um conjunto de procedimentos formais, legalmente embasados, pelo qual o Estado busca a proposta mais vantajosa para a Administração Pública. 
A ilustração constante da figura 4 mostra de um modo geral, como é o processo de uma licitação como um todo:

Figura 4 - Passos de um processo de licitação

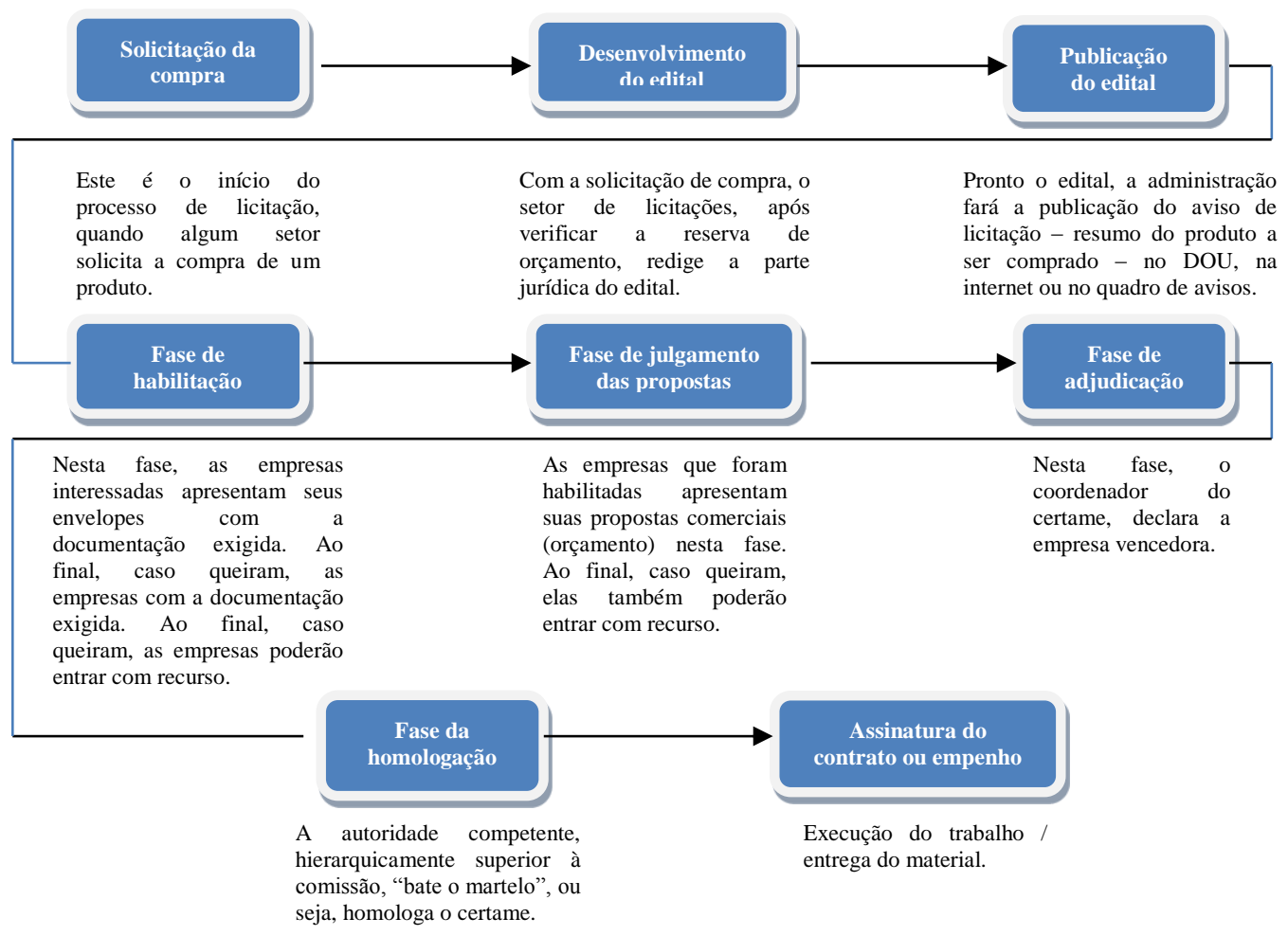

Fonte: Elaborado pelo autor.

\subsection{Pregão}

Com o surgimento da Administração Pública gerencial, sedimentada nos princípios da confiança e da descentralização da decisão, acrescido às tecnologias de comunicação e informação, foi atribuída ao Estado uma postura de eficiência e modernidade nos processos de compras e serviços, assim como nas relações do Estado com o cidadão.

A partir destas transformações na Administração Pública, formas mais flexível de gestão foram sendo exigidas. O conteúdo de licitações e contratos administrativos precisou ser de certa forma revisto, uma vez que o princípio da eficiência tinha tomado tamanho posicionamento constitucional.

No intuito de fazer prevalecer o princípio constitucional da eficiência, conduziu-se de maneira cada vez mais intensa, que o verdadeiro objetivo na realização de processos licitatórios fosse a busca pelas melhores propostas, ou seja, aquelas mais vantajosas para o interesse público, não se deixando limitar pelas incalculáveis e desnecessárias exigências 
burocráticas na fase de habilitação. Assim, eis que surge no sistema brasileiro o procedimento licitatório denominado "Pregão", o qual provocou grandes mudanças no universo das licitações públicas.

De acordo com Scarpinella (2002), o pregão surgiu no sistema brasileiro em 1997, pela Lei Geral de Telecomunicações, que criou a Anatel, dando a ela independência administrativa, o que proporcionou autonomia para criação de novas regras organizacionais. Neste contexto, a legislação em pauta estabeleceu um regime próprio de contratações para a Anatel, dando surgimento ao Pregão como nova modalidade de licitação e de aplicação restrita à entidade.

Após quase três anos de resultados positivos na Anatel, e, diante de inúmeras críticas acerca da burocratização do procedimento licitatório, o Governo Federal, com o objetivo de propiciar a este procedimento maior celeridade para a aquisição de bens e serviços comuns, optou por estender esta modalidade para a Administração Pública, editando uma Medida Provisória em maio de 2000, na qual instituiu o Pregão no âmbito da União. Após sofrer sucessivas reedições, a Medida Provisória em questão passou a ser estendida a todos os entes da Federação em julho de 2002, com a publicação da Lei 10.520 (BRASIL, 2002).

O pregão eletrônico é operacionalizado pelo Sistema Comprasnet, o qual viabiliza a sessão pública de licitação em ambiente eletrônico, entre os licitantes (vendedores) e a Administração (compradora). A modalidade de licitação em questão apresenta características básicas de um leilão. Porém, é declarado vencedor aquele que enviar a proposta de menor preço e não maior, como ocorre nos leilões tradicionais. Desta forma, é também conhecido como leilão reverso, por contemplar a inversão entre as fases de habilitação e julgamento. Assim, somente após o julgamento das propostas é que se iniciará o processo de habilitação e neste caso, apenas da empresa melhor classificada.

Esta modalidade implicou em mudanças estruturais e procedimentais para as licitações públicas. Em relação ao procedimento em si, o processo é dividido em duas fases: 1) fase interna, a qual compreende toda a instrução processual, obtenção de autorizações, recursos orçamentários e análise jurídica, com vistas a dar prosseguimento à contratação; e 2) fase externa, a partir da qual é utilizado o Sistema Comprasnet.

A fase interna representa a etapa crucial do pregão para obter, posteriormente, os preços mais competitivos. Nela, segundo Oura et al. (2012), é elaborado um Termo de Referência, documento balizador da licitação, a partir do qual será redigido o edital e a minuta 
de contrato, os quais serão posteriormente, disponibilizados em meio eletrônico, aos licitantes na fase externa do certame. É nele que constará o valor estimado (resultado de simples média aritmética), a ser divulgado para os licitantes durante a etapa de lances na fase externa para a contratação, obtido pelas diversas áreas demandantes da instituição, por meio de pesquisa de mercado junto aos diversos fornecedores.

Entretanto, na UnB, essa fase processual ainda ocorre de maneira manual, sem a utilização de qualquer tipo de sistema de gerenciamento dos preços orçados no passado ou monitoramento do ambiente externo.

Segundo Oura et al. (2012), a exigência da pesquisa de preços de mercado para se estimar o valor da licitação, é um tanto controversa, na medida em que não há segurança de que os preços providos pelos fornecedores sejam os mesmos praticados em suas operações cotidianas. Para os autores, esse fato permite inferir que essas empresas podem onerar substancialmente os valores nesta fase da licitação, a fim de auferir lucros adicionais na futura licitação, isto é, quando entrarem como licitantes para os produtos para os quais forneceram os preços de mercado, cujas médias tornam-se os preços de referência do edital.

Contudo, Santana (2008, p. 34), avalia que “pregão e gestão fiscal responsável”, são alguns ingredientes que alteraram as arcaicas estruturas administrativas no Brasil. De acordo com a legislação, o pregão pode ser realizado por duas formas: presencial e eletrônico. De acordo com Reis (2008, p. 38):

Na sua forma presencial, o pregão transcorrerá em sessão pública, destinada ao recebimento de envelopes proposta e habilitação, com posterior oferecimento de lances verbais pelos licitantes, cujo procedimento seguirá o rito disposto na Lei 10.520 .

Em relação ao pregão eletrônico, o autor cita alguns diferenciais como:

O credenciamento dos participantes ocorre antes da sessão, pois o licitante deve estar cadastrado junto ao órgão responsável pelo sistema a ser utilizado na Internet; o certame ocorrerá por meio eletrônico, cujo sistema operacional é escolhido pela entidade licitante e detalhado no instrumento convocatório; todos os atos da sessão são processados por meio eletrônico.

O autor esclarece, ainda, que outra característica é o tempo randômico. No pregão eletrônico existem dois momentos na fase de lances. No primeiro momento o pregoeiro é quem controla o tempo de lance para cada lote, e quando o pregoeiro encerra o primeiro momento de lance, é iniciado o segundo momento, chamado de tempo randômico, que é controlado pelo sistema, podendo chegar a um máximo de tempo pré-estabelecido. 
Após o encerramento dos lances, as empresas vencedoras devem encaminhar sua documentação de habilitação para a instituição licitante, que segue os mesmos trâmites do pregão presencial, findando com a homologação divulgada no cenário eletrônico.

Instituído para aquisição de bens e serviços comuns cujos padrões podem ser definidos objetivamente, o Pregão é uma a modalidade de licitação na qual a disputa pelo fornecimento é feita em sessão pública, por meio de propostas e lances, para classificação e habilitação do licitante com a proposta de menor preço.

Para Andrade e Santana (2008, p.70), a definição do objeto faz parte da fase preparatória do pregão, conforme determina a legislação:

“... a autoridade competente... definirá o objeto do certame, as exigências de habilitação, os critérios de aceitação das propostas, as sanções por inadimplemento e as cláusulas do contrato...”; “... a definição do objeto deverá ser precisa, suficiente e clara, vedadas especificações... que limitem a competição...”.

Definida a fase preparatória do pregão, é realizada a fase externa do procedimento. Scarpinella (2002, p. 104) cita que nesta etapa é preciso cumprir o princípio da publicidade, dando ampla divulgação do edital, seja por Diário Oficial, jornal de circulação local, meio eletrônico e disponibilização do edital em local público. A publicação do aviso caracteriza-se como o ato de comunicação pelo qual se dá ciência da abertura do pregão, a fím de que os interessados possam apresentar suas propostas, providenciar os documentos de habilitação hábeis à sua participação no certame licitatório e providenciar, querendo, o credenciamento de seu representante na licitação.

Rigolin e Bottino (2002, p.453) complementam que o extrato do edital deve conter:

“... local, data e horário em que pode ser obtido o edital...”. Informam ainda que estes dados são aqueles que a lei exige, porém é importante constar no aviso o nome da instituição licitante, o objeto, a previsão da modalidade e a indicação do local onde será realizado o certame.

Na sequência, segundo Scarpinella (2002, p. 110 a 111) são realizadas as seguintes etapas da fase externa do pregão:

- Fase inicial: quando se verifica a admissibilidade das propostas para a fase subsequente. Envolve a comprovação de poderes pelo licitante para a prática dos atos relativos ao certame e a entrega de declaração de cumprimento dos requisitos de habilitação;

- Fase de julgamento: quando se escolhe a melhor proposta. Consiste de uma cadeia sequencial de atos, determinada pela inversão das fases de habilitação e julgamento. Nela estão incluídas: (a) análise da conformidade das propostas ao edital; (b) apresentação de amostras no pregão; (c) regra dos 10\%, determinante dos licitantes que 
participarão dos lances; (d) etapa de lances propriamente dita; (e) aferição da aceitabilidade da proposta vencedora; (f) análise da exequibilidade do valor ofertado; e (g) negociação com o vencedor;

- Fase de habilitação: momento para análise das condições pessoais necessárias para a celebração do contrato. No Pregão esta fase é subsequente à de julgamento e envolve a verificação da documentação de habilitação apenas do licitante vencedor;

- Fase de recursos: que se caracteriza pela sua concentração ao final da sessão pública. Apenas após a declaração do vencedor é que se inicia o momento processual para a apresentação de recursos contra quaisquer atos praticados ao longo da sessão;

- Fase de adjudicação: momento que antecede a homologação do certame, dando por encerrado o trabalho de escolha do licitante;

- Fase de homologação: última etapa do procedimento do pregão que envolve a análise de todo o ocorrido, por autoridade competente e posterior assinatura do contrato.

A fase externa do pregão será iniciada com a convocação dos interessados e o prazo fixado para a apresentação das propostas, contado a partir da publicação do aviso, não poderá ser inferior a oito dias úteis. De acordo com a Lei do Pregão, até dois dias antes da data fixada para recebimento das propostas, qualquer pessoa poderá solicitar esclarecimentos, providências ou impugnar o ato convocatório do pregão. Nesse sentido, caberá ao pregoeiro decidir sobre a petição no prazo de vinte e quatro horas e caso seja acolhida a petição contra o ato convocatório, será designada nova data para a realização do certame.

De acordo com Scarpinella, (2002, p. 96), para executar as ações da fase externa do pregão criou-se a figura do pregoeiro, que junto com a equipe de apoio, conduz os procedimentos. A ele foi dado o encargo de tomar as decisões ao longo do certame, sendo que a dinâmica do processo exige que ele conheça o mercado fornecedor e tenha informação sobre custos envolvidos.

No mesmo sentido, Santana (2008, p. 127) salienta que ao pregoeiro são destinadas funções como: abertura da sessão e credenciamento dos interessados; recebimento das propostas e documentos de habilitação; abertura dos envelopes proposta e verificação da sua conformidade com o edital; classificação/desclassificação das propostas; condução da etapa de lances; aceitabilidade do melhor lance; verificação da regularidade habilitatória; declaração 
do vencedor; recebimento da intenção de recursos e juízo do recurso; adjudicação do objeto ao vencedor; leitura da ata; e remessa dos autos à autoridade competente para homologação.

Para auxiliar o pregoeiro, foi criada a equipe de apoio que, segundo Scarpinella (2002, p. 100), não tem competência decisória, mas apenas de assistência ao pregoeiro.

Uma novidade advinda do pregão é a inversão das fases, onde primeiro é realizada a abertura das propostas e, após ocorrer os lances, é aberto o envelope contendo a documentação de habilitação do licitante que ofertou o melhor lance.

Nesta modalidade não se impõe limite de valor para contratações. Scarpinella (2002, p. 75) explana que no pregão não há relação entre o procedimento e o valor da futura contratação, desde que o objeto a ser licitado seja um bem ou serviço comum.

Outro diferencial do pregão é a disputa por meio de lances, o que possibilita aos fornecedores a redução dos seus preços. Andrade e Santana $(2008$, p. 71) descrevem que a Lei Federal prevê o seguinte:

“... no curso da sessão, o autor da oferta de valor mais baixo e os das ofertas com preços até $10 \%$ (dez por cento) superiores àquela poderão fazer novos lances verbais e sucessivos, até a proclamação do vencedor...;" e "...não havendo pelo menos 3 (três) ofertas nas condições definidas no inciso anterior poderão os autores das melhores propostas, até o máximo de 3 (três), oferecer novos lances verbais e sucessivos, quaisquer que sejam os preços oferecidos...".

A fase de lances objetiva reduzir o preço do objeto ofertado e incentivar a competição entre os fornecedores.

Após a fase de lances é realizada uma análise na documentação de habilitação do licitante que ofereceu o menor preço que, caso esteja de acordo com os preceitos estabelecidos em lei, implicará na declaração do vencedor. Em seguida, o objeto é a ele adjudicado e o processo é encaminhado à autoridade competente para homologação, assinatura de contrato e autorização da execução do objeto.

O quadro a seguir apresenta as principais diferenças entre o Pregão Presencial e o

\section{Pregão Eletrônico:}

Quadro 2 - Principais diferenças entre o Pregão Presencial e o Pregão Eletrônico

\begin{tabular}{|l|l|l|}
\hline \multicolumn{1}{|c|}{ Aspecto } & \multicolumn{1}{|c|}{ Pregão Presencial } & \multicolumn{1}{c|}{ Pregão Eletrônico } \\
\hline Sessão pública & $\begin{array}{l}\text { Sessão pública com a presença dos } \\
\text { licitantes. }\end{array}$ & Envio de informações à distância (via internet). \\
\hline Lances & $\begin{array}{l}\text { O licitante autor da menor proposta } \\
\text { e os demais que apresentarem } \\
\text { preços até 10\% superiores a ela }\end{array}$ & $\begin{array}{l}\text { Todos os licitantes, cujas propostas não foram } \\
\text { desclassificadas, podem oferecer lances. }\end{array}$ \\
& $\begin{array}{l}\text { estão classificados para fase de } \\
\text { lances. Caso não haja pelo menos } \\
\text { três licitantes que atendam essas }\end{array}$ & \\
\hline
\end{tabular}




\begin{tabular}{|c|c|c|}
\hline Aspecto & Pregão Presencial & Pregão Eletrônico \\
\hline & $\begin{array}{l}\text { condições, deverão ser convocados } \\
\text { para essa fase os demais, obedecida } \\
\text { a ordem de classificação das } \\
\text { propostas, até o máximo de três, } \\
\text { quaisquer que sejam os preços } \\
\text { oferecidos por eles. }\end{array}$ & \\
\hline $\begin{array}{l}\text { Autoria dos } \\
\text { lances }\end{array}$ & $\begin{array}{l}\text { Os presentes na sessão sabem quem } \\
\text { são os autores dos lances. }\end{array}$ & $\begin{array}{l}\text { É vedada a identificação dos licitantes responsáveis } \\
\text { pelos lances. }\end{array}$ \\
\hline Ordem dos lances & $\begin{array}{l}\text { Os licitantes são classificados de } \\
\text { forma sequencial e apresentam } \\
\text { lances verbais a partir do autor da } \\
\text { proposta classificada de maior } \\
\text { preço e os demais, em ordem } \\
\text { decrescente de valor. }\end{array}$ & $\begin{array}{l}\text { Os licitantes podem oferecer lances sucessivos, } \\
\text { independentemente da ordem de classificação. }\end{array}$ \\
\hline $\begin{array}{l}\text { Término da fase } \\
\text { de lances }\end{array}$ & $\begin{array}{l}\text { Ocorre quando não houver lances } \\
\text { menores que o último ofertado. }\end{array}$ & $\begin{array}{l}\text { Ocorre por decisão do pregoeiro e o sistema } \\
\text { eletrônico encaminha aviso de fechamento iminente } \\
\text { dos lances, após o que transcorrerá o período de até } \\
\text { trinta minutos, aleatoriamente determinado. }\end{array}$ \\
\hline Habilitação & $\begin{array}{l}\text { A documentação da habilitação não } \\
\text { contemplada no SICAF deve ser } \\
\text { apresentada em envelope lacrado. }\end{array}$ & $\begin{array}{l}\text { Os documentos de habilitação que não estejam } \\
\text { contemplados no SICAF, inclusive quando houver } \\
\text { necessidade de envio de anexos, devem ser } \\
\text { apresentados via fax após a solicitação do pregoeiro } \\
\text { no sistema eletrônico. }\end{array}$ \\
\hline Recursos & $\begin{array}{l}\text { A intenção do licitante de recorrer } \\
\text { deve ser feita de forma verbal, no } \\
\text { final da sessão, com registro em ata } \\
\text { da síntese das razões. }\end{array}$ & $\begin{array}{l}\text { A intenção de recorrer pode ser realizada pelo } \\
\text { licitante, de forma imediata e motivada, em campo } \\
\text { próprio no sistema eletrônico. }\end{array}$ \\
\hline
\end{tabular}

Fonte: Spinelli e Luciano (2015).

\subsection{Princípios básicos do Pregão}

Inicialmente, cumpre ressaltar que o pregão é balizado por todos os princípios básicos que determinam as demais modalidades de procedimento licitatório e por alguns princípios essenciais da modalidade pregão.

Para compreendê-lo, é fundamental perceber os princípios que o envolvem. Sem conhecer os princípios, não se alcança a essência da modalidade pregão e, em razão disso, muitas questões a respeito dela acabam sendo interpretadas de forma equivocada.

Nesse contexto, a modalidade pregão é determinada pelos princípios básicos da legalidade, impessoalidade, da moralidade, igualdade, da publicidade, da probidade administrativa, da vinculação ao instrumento convocatório, do julgamento objetivo, bem como pelos princípios ligados à celeridade, finalidade, razoabilidade, proporcionalidade, competitividade, justo preço, seletividade e comparação objetiva das propostas. Niebuhr (2004) expõe os mais importantes princípios básicos do pregão: 
- Princípio da isonomia - Este é o princípio mais importante para a licitação. Segundo este princípio, os contratos administrativos geram benefício econômico ao contratado. Como todos os interessados em colher tais benefícios econômicos devem ser tratados com igualdade, por força do caput do artigo $5^{\circ}$ da Constituição Federal, impõe-se à Administração seguir certas formalidades para escolher com quem contratar, ou seja, quem será o beneficiário;

- Princípio da eficiência e os subprincípios da celeridade, finalidade, justo preço e seletividade - A eficiência em licitação pública gira em torno de três aspectos fundamentais: preço, qualidade e celeridade, sendo que do princípio da eficiência, decorrem outros princípios, quais sejam: de justo preço, seletividade, celeridade e finalidade;

- Princípio da legalidade - Para as pessoas privadas, o princípio da legalidade, consoante o inciso II do artigo $5^{\circ}$ da Constituição Federal, significa que "ninguém será obrigado a fazer ou deixar de fazer alguma coisa senão em virtude de lei”. Em razão disso, é reconhecido o ditado segundo o qual o que não é proibido é permitido, isto é, se a lei não proíbe determinada consulta, ela é permitida. (NIEBUHR, 2004, p. 41). Noutro lado, para a Administração Pública, o princípio da legalidade reveste-se de tonalidade especial. Ocorre que os agentes administrativos não atuam com liberdade, para atingir fins que reputem convenientes. Ao contrário, eles estão vinculados ao cumprimento do interesse público, uma vez que atuam nos estritos termos da competência que lhe foi atribuída por lei;

- Princípio da vinculação ao edital - No edital, a Administração Pública deverá registrar o que pretende contratar, ou seja, qual o objeto do contrato e, por dedução, da licitação pública, com todas as suas especificidades (artigo 40 da Lei no 8.666/93). Os licitantes, ao analisarem o edital, deverão ter condições de precisarem tudo o que serão obrigados a fazer caso saiam vencedores do certame. E, por outro lado, a Administração Pública só pode exigir aquilo que efetivamente estiver no edital, salvo se alterar o contrato, dentro dos limites legais, restabelecendo o equilíbrio econômicofinanceiro. $\mathrm{O}$ instrumento convocatório deve evidenciar os documentos a serem apresentados pelos licitantes para que sejam habilitados no certame, e, ainda em linha geral, deve anunciar os critérios objetivos a serem levados em conta para cortejar as propostas; 
- Princípio da moralidade - O princípio da moralidade relaciona-se aos padrões morais, isto é, aos comportamentos determinados como honestos e virtuosos pelos membros da sociedade. A moralidade posta no meio administrativo quer adicionar força ao princípio da legalidade, evitando que agentes administrativos maculem as competências que lhes foram atribuídas por lei para a prática de atos incompatíveis com os valores que a sociedade considera acertados. Para o Direito Administrativo, a moralidade significa harmonia com o interesse público, vetor máximo de todos os princípios e regras que informam, revelando-se intimamente ligado à legitimidade;

- Princípio da publicidade - Trata-se de um princípio que visa a legitimar a atividade administrativa, permitindo que todos os membros da sociedade tenham conhecimento dos atos e de quaisquer dados de seu interesse. Para a licitação pública, o princípio da publicidade é de vital importância. Sem ele, já não se poderia falar em licitação pública, mas tão-somente em licitação privada. Sem publicidade não há utilidade em realizar licitação;

- Princípio da competitividade - O princípio da competitividade significa exigência de que a Administração Pública assegure e busque adicionar à licitação pública, o maior número de interessados, para que com vistas na eficiência e na isonomia, aumentando o universo das propostas que lhes são encaminhadas, ela possa legitimamente, escolher aquela que seja a mais vantajosa ao interesse público. (NIEBUHR, 2004, p. $44)$;

- Princípio da razoabilidade e da proporcionalidade - Os princípios da razoabilidade e da proporcionalidade são fundamentais para o controle da discricionariedade concedido em favor dos agentes administrativos. Ocorre que, inúmeras vezes, a Lei não predetermina a melhor solução para o interesse público, mas outorga aos agentes administrativos a competência para fazê-lo, em vista das particularidades dos casos concretos que lhes são apresentados;

- Princípio do Julgamento Objetivo - O princípio do julgamento objetivo sustenta abstrair ao máximo o subjetivismo no cotejo das propostas apresentadas. Sem embargo, o julgamento objetivo agrega-se ao instrumento convocatório, pois os critérios do julgamento nele estão previstos. Neste desígnio, o julgamento objetivo é aquele que se dá na estrita conformidade dos parâmetros prefixados no edital. 
Ainda em relação ao Pregão, foi criada a Lei Complementar no 123/2006 com a finalidade de estabelecer normas gerais relativas ao tratamento diferenciado e favorecido a ser dispensado às microempresas e empresas de pequeno porte. Lima apud Souza e Castro (2012), afirma que:

A Lei Complementar 123/06 veio para regulamentar o "tratamento diferenciado" às Microempresas e Empresas de Pequeno Porte, previsto como princípio no artigo 170 da Constituição Federal, bem como dar efetividade ao outro comando, inserido no artigo 179 da mesma carta magna, de "tratamento diferenciado" às Microempresas e Empresas de Pequeno Porte.

Segundo Santana et al. (2011, p. 128) esta lei traz benefícios para as micro e pequenas empresas nas aquisições públicas. Para o autor, um destes benefícios está vinculado à regularidade fiscal. Quando participam de licitações, as empresas devem apresentar a documentação habilitatória, porém, sendo detectada alguma irregularidade, elas têm a prerrogativa de apresentar tais certidões, sem restrição, em prazo posterior estabelecido pela norma.

Outra particularidade é que, em caso de empate entre licitantes, a preferência seja pela contratação das microempresas (ME) ou empresas de pequeno porte (EPP), sendo que o empate é caracterizado quando as propostas apresentadas por ME e EPP sejam iguais ou até $5 \%$ superiores à proposta mais bem classificada. Contudo, alerta Lima apud Souza e Castro (2012), o desempate depende de apresentação de nova proposta com preço inferior àquela considerada vencedora do certame.

Segundo o autor, também é possível realizar licitações destinadas exclusivamente às ME e EPP para contratações dentro de determinados valores convencionados. Ressalta-se ainda que o tratamento diferenciado concedido às ME e EPP, tem por objetivo, a promoção do desenvolvimento econômico e social no âmbito municipal e regional.

\subsection{Pregão e o Sistema de Registro de Preços}

Em meio ao universo da Administração Pública, que adquire, contrata e aliena bens, surge uma ferramenta para auxiliar o administrador público, o Sistema de Registro de Preços (SRP). A legislação do SRP está sedimentada no art. 15 da Lei Federal de Licitações editada em 1993, regulamentado no âmbito Federal pelo até então Decreto no 3.931/01.

Contudo, em 23 de janeiro de 2013 foi publicado o Decreto Federal n 7.892/13, invalidando assim o Decreto Federal 3.931/01 e estabelecendo novas regras para o sistema de registro de preços. 
De acordo com Santana et al. (2011, p. 22), as compras, sempre que possível, deverão ser processadas pelo sistema de registro de preço. Para ele, o SRP é um conjunto de procedimentos para registro formal de preços relativos à aquisição de bens e prestação de serviços, para contratações futuras.

O registro de preços exige, antes de tudo, o planejamento por parte da Administração pública, pois é nesse momento que se deve planejar o que vai ser adquirido, e para tanto, a quantidade nesse período não poderá exceder a um ano.

No registro de preços a Administração Pública deve determinar o objeto, elaborar minutas dos editais de maneira clara, enviar correspondências convidando outras entidades a participarem e continuamente lembrando que a licitação tem em foco o Registro de Preços.

Justen Filho (2004) enumera diversas vantagens quanto à utilização do SRP. Dentre as vantagens são citadas:

Redução dos gastos e simplificação administrativa; rapidez na contratação e otimização dos gastos; validade das propostas de até um ano; contratação da quantidade que for adequada à satisfação do interesse público; escolha em momento apropriado de produtos, segundo a qualidade necessária à satisfação dos seus interesses no caso concreto, e aquisições para diversos órgãos ou entidades com apenas um procedimento licitatório.

Furtado (2007) também destaca vantagens do SRP. Para o autor, o SRP, por não necessitar de orçamento prévio para realizar a licitação, permite maior flexibilidade ao gestor público, pois torna mais rápido o procedimento de contratação. Furtado (2007, p. 5) lembra ainda que:

\footnotetext{
A utilização do SRP também é importante quando a Administração desconhece a demanda de um novo objeto, ou mediante as variações no aumento do consumo de um objeto já previsto, em tais proporções que se tornam impossíveis de ser aditivadas nos percentuais exigidos por lei, como também, propiciar o ganho de escala.
}

Na mesma linha, o professor Jacoby Fernandes (2006) indica que o SRP é um importante instrumento de gestão, quando as demandas são incertas, frequente ou de difícil mensuração.

Furtado (2007) aponta outro ponto positivo do Registro de Preços:

Empregando o SRP, a Administração pode licitar o quantitativo necessário para todo o exercício e, à medida que for sendo liberado o orçamento, efetivar a contratação. Isso propicia um maior aproveitamento do estoque, sem perdas de produtos em função de prazos de validade ou má conservação e armazenamento.

Outra vantagem refere-se à exigência de desempenho por parte da Administração Pública, ao aplicar os recursos colocados a sua disposição. Assim, ganha ênfase o princípio da eficiência e economicidade. 
Fernandes Thiago (2008) enumera um amplo rol das vantagens do SRP:

Não é necessária a existência de dotação orçamentária; atendimento à imprevisibilidade de demandas; redução dos volumes de estoques e da quantidade de licitações; agilidade nas aquisições; transparência; diminuição do fracionamento de despesas; flexibilidade na atualização dos preços; participação de pequenas e médias empresas; economicidade e eficiência.

A sistemática do registro de preços exige do gestor, dedicação no seu acompanhamento. É necessária uma físcalização quanto ao cumprimento das condições acordadas por parte da empresa durante toda a vigência da ata de registro de preços, em especial quanto aos preços registrados em relação aos praticados no mercado, procedendo à negociação quando da variação do preço registrado em comparação aos praticados no mercado. Além disso, proceder à responsabilização pelas eventuais aplicações de penalidades, caso haja descumprimento do compromisso em ata, conforme previsto no instrumento convocatório.

A manutenção da regularidade da documentação da empresa durante toda a vigência é de observância obrigatória e requer fiscalização, pois é fator determinante para se efetivar a contratação.

\subsection{O Sistema de Registro de Preços e a figura do "carona"}

Não obstante as vantagens relatadas em linhas passadas, o SRP tem gerado polêmicas quanto à figura do "carona", isto é, a possibilidade de órgão ou entidade que não tenha participado da licitação que originou a Ata de Registro de Preços, a ela aderir como se sua fosse, especialmente nas situações que envolvem poderes ou níveis de governo distintos. A adesão à ata era disciplinada até então pelo art. $8^{\circ}$ do Decreto n. 3.931/2001:

Art. $8^{\circ}$ A Ata de Registro de Preços, durante sua vigência, poderá ser utilizada por qualquer órgão ou entidade da Administração que não tenha participado do certame licitatório, mediante prévia consulta ao órgão gerenciador, desde que devidamente comprovada a vantagem.

$\S 1^{\circ}$ Os órgãos e entidades que não participaram do registro de preços, quando desejarem fazer uso da Ata de Registro de Preços, deverão manifestar seu interesse junto ao órgão gerenciador da Ata, para que este indique os possíveis fornecedores e respectivos preços a serem praticados, obedecidos a ordem de classificação.

$\S 2^{\circ}$ Caberá ao fornecedor beneficiário da Ata de Registro de Preços, observadas as condições nela estabelecidas, optar pela aceitação ou não do fornecimento, independentemente dos quantitativos registrados em Ata, desde que este fornecimento não prejudique as obrigações anteriormente assumidas.

$\S 3^{\circ}$ As aquisições ou contratações adicionais a que se refere este artigo não poderão exceder, por órgão ou entidade, a cem por cento dos quantitativos registrados na Ata de Registro de Preços. 
Justen Filho (2010, p. 207) leciona que:

Em síntese, "carona" consiste na contratação fundada num sistema de registro de preços em vigor, mas envolvendo uma entidade estatal dele não participante originalmente, com a peculiaridade de que os quantitativos contratados não serão computados para o exaurimento do limite máximo.

Por sua vez, ao discorrer sobre o "carona", Jacoby Fernandes (2007), exalta a busca pela proposta mais vantajosa:

O carona no processo de licitação é um órgão que antes de proceder à contratação
direta sem licitação ou a licitação verifica já possuir, em outro órgão público, da
mesma esfera ou de outra, o produto desejado em condições de vantagem de oferta
sobre o mercado já comprovadas. Permite-se ao carona que diante da prévia licitação
do objeto semelhante por outros órgãos, com acatamento das mesmas regras que
aplicaria em seu procedimento, reduzir os custos operacionais de uma ação seletiva.
É precisamente nesse ponto que são olvidados pressupostos fundamentais da
licitação enquanto processo: a finalidade não é servir aos licitantes, mas ao interesse
público; a observância da isonomia não é para distribuir demandas uniformemente
entre os fornecedores, mas para ampliar a competição visando a busca de proposta
mais vantajosa.

A adesão do "carona" é convencionada de algumas etapas. Em linhas gerais, primeiramente verifica-se a vantagem, validade e compatibilidade da Ata de Registros de Preços que se pretende aderir. Em seguida, solicita-se a aquiescência e a intervenção do órgão gestor para negociar com o fornecedor sua "participação". O fornecedor é contatado para explicitar as condições de preço e fornecimento e, contanto que isso não prejudique as obrigações já compactuadas, poderá aceitar fornecer o bem ou prestar o serviço.

De acordo com Dorella e Soares (2013), a figura do "carona" no SRP admitiu significativas mudanças com a publicação do Decreto Federal n ${ }^{\circ} 7.892 / 13$, o qual revogou o Decreto $^{\mathrm{o}} 3.931 / 01$, passando a regimentar o disposto no art. 15 da Lei. 8.666/93.

Para os autores, a ausência de limites às aquisições realizadas por órgãos não participantes "caronas", causou uma série de controvérsias na doutrina. Nesse sentido havia doutrinadores que defendiam a legalidade da figura do "carona" trazida pelo art. $8^{\circ}$ do Decreto Federal no 3.931/01, sob o argumento de que este sistema propõe maior celeridade e eficiência às contratações públicas, impedindo-se a realização irrelevante de diversos procedimentos licitatórios para o mesmo propósito.

Por outro lado, outros argumentavam que a figura do "carona" infringia diversos princípios que regulamentam a contratação pública (art. $3^{\circ}$, da Lei $n^{\circ}$ 8.666/93), exclusivamente no que se refere à obrigatoriedade de licitação conforme prevê o art. 37, XXI da Carta Magna de 1988.

Entretanto, Dorella e Soares (2013), destacam ainda que apesar do Tribunal de Contas da União (TCU), via de regra, não impossibilitar a adoção da figura do "carona”, ele já vinha, 
por meio de suas deliberações, introduzindo ressalvas à adesão ilimitada de órgãos não participantes do certame às atas de registros.

Assim sendo, com o intuito de dirimir as controvérsias acerca do tema, especialmente no que se refere à figura do "carona", surgiu o Decreto Federal $n^{\circ} 7.892 / 13$, determinando novos critérios para limitar a adesão às atas de registros de preços por órgãos ou empresas não participantes no respectivo processo licitatório.

O decreto supracitado tentou esclarecer as várias celeumas em torno do tema, com a destinação de um capítulo específico inteiro para a regulamentação do "carona", estipulando novos critérios para limitar a adesão às atas de registro de preços, expondo expressamente o seguinte:

Art. 22 - Desde que devidamente justificada a vantagem, a ata de registro de preços, durante sua vigência, poderá ser utilizada por qualquer órgão ou entidade da administração pública federal que não tenha participado do certame licitatório, mediante anuência do órgão gerenciador.

$\S 1^{\circ}$ Os órgãos e entidades que não participaram do registro de preços, quando desejarem fazer uso da ata de registro de preços, deverão consultar o órgão gerenciador da ata para manifestação sobre a possibilidade de adesão.

$\S 2^{\circ}$ Caberá ao fornecedor beneficiário da ata de registro de preços, observadas as condições nela estabelecidas, optar pela aceitação ou não do fornecimento decorrente de adesão, desde que não prejudique as obrigações presentes e futuras decorrentes da ata, assumidas com o órgão gerenciador e órgãos participantes.

$\S 3^{\circ}$ As aquisições ou contratações adicionais a que se refere este artigo não poderão exceder, por órgão ou entidade, a cem por cento dos quantitativos dos itens do instrumento convocatório e registrados na ata de registro de preços para o órgão gerenciador e órgãos participantes.

$\S 4^{\circ} \mathrm{O}$ instrumento convocatório deverá prever que o quantitativo decorrente das adesões à ata de registro de preços não poderá exceder, na totalidade, ao quíntuplo do quantitativo de cada item registrado na ata de registro de preços para o órgão gerenciador e órgãos participantes, independente do número de órgãos não participantes que aderirem.

$\S 5^{\circ} \mathrm{O}$ órgão gerenciador somente poderá autorizar adesão à ata após a primeira aquisição ou contratação por órgão integrante da ata, exceto quando, justificadamente, não houver previsão no edital para aquisição ou contratação pelo órgão gerenciador.

$\S 6^{\circ}$ Após a autorização do órgão gerenciador, o órgão não participante deverá efetivar a aquisição ou contratação solicitada em até noventa dias, observado o prazo de vigência da ata.

$\S 7^{\circ}$ Compete ao órgão não participante os atos relativos à cobrança do cumprimento pelo fornecedor das obrigações contratualmente assumidas e a aplicação, observada a ampla defesa e o contraditório, de eventuais penalidades decorrentes do descumprimento de cláusulas contratuais, em relação às suas próprias contratações, informando as ocorrências ao órgão gerenciador.

$\S 8^{\circ}$ É vedada aos órgãos e entidades da administração pública federal a adesão a ata de registro de preços gerenciada por órgão ou entidade municipal, distrital ou estadual. 
$\S 9^{\circ}$ É facultada aos órgãos ou entidades municipais, distritais ou estaduais a adesão a ata de registro de preços da Administração Pública Federal.

Em relação ao tema o Ministro do TCU, Benjamin Zymler, fez o seguinte comentário:

Gosto da ideia da limitação do Carona. O Decreto estabelece que no edital da licitação já tenha que contemplar o quantitativo para órgão gerenciador e participante e o quantitativo dos órgãos aderentes. E esse quantitativo está limitado a cinco vezes o valor do quantitativo para gerenciador e participantes, e para cada aderente $100 \%$. (ZIMLER, 2013, p. 32).

O professor Jacoby Fernandes (2013, p. 35), exprimiu a seguinte opinião:

Importante esclarecer, entre as inovações, é que foi mantido o carona, apesar da maioria dos doutrinadores viverem reclamando da sua inconstitucionalidade, da sua ilegalidade, ele foi mantido porque realmente está conforme a Lei.

Apesar das várias controvérsias criadas em torno da figura do "carona", fato é que, de acordo com os especialistas na área doutrinária, não há previsão em lei para o "carona”, o qual é regulamentado apenas por decreto. Por outro lado, não há vedações legais que impeçam a sua prática, nem mesmo entre diferentes esferas de governo. 


\section{ESTUDO DE CASO}

O capítulo em questão tem por objetivo descrever o Planejamento de Compras da UnB, lócus da pesquisa, com o uso do Pregão em sua forma eletrônica.

\subsection{Planejamento de Compras na Universidade de Brasília}

Na Administração Pública, o planejamento de compras é de suma importância, sobretudo, considerando que a crescente preocupação com a questão logística das compras no Setor Público, exige que os gestores planejem suas atividades com a finalidade de satisfazer os seus clientes, ou seja, a sociedade - quem contribui por meio dos tributos para a prestação dos serviços pelo governo - com o mínimo possível de recursos, otimizando o desempenho logístico.

Nessa linha de raciocínio, a realização do processo de compras é uma etapa de grande relevância para qualquer instituição e o seu procedimento deve ser rápido e eficiente. Nele, deve-se evitar o desperdício de recursos e de tempo. Além disso, a simples opção pela compra do produto mais barato pode não ser eficiente, pois, em muitas situações o produto de menor preço não possui qualidade adequada. Sob esta ótica, quanto mais eficiente for o sistema adotado pelo administrador em relação aos procedimentos licitatórios, melhor será a eficiência alocativa dos recursos públicos na economia.

Assim sendo, um dos objetivos fundamentais a ser perseguido em gestão pública é o uso racional do dinheiro público. Logo, o Governo deve buscar melhores formas de atendimento às demandas da população, com o máximo de economia, rapidez, lisura, transparência e principalmente, atendendo aos preceitos da legislação.

Para tanto, a Administração Pública carece contratar atividades junto ao setor privado através de instrumentos contratuais, os quais dependem, em regra, de um procedimento que selecione previamente o fornecedor, denominado de licitação pública.

$\mathrm{Na}$ qualidade de Instituição Pública e, portanto, sujeita às normas em vigor para contratação de atividades junto ao setor privado, a Universidade de Brasília para prover as suas necessidades de materiais, equipamentos e serviços destinados ao ensino, pesquisa e extensão, vê-se obrigada a lançar mão do processo de licitação pública.

Atualmente, as demandas de compras oriundas de seus quatro campi: Darcy Ribeiro, Planaltina, Ceilândia e Gama, estão centralizadas na Diretoria de Compras localizada no 
Campus Darcy Ribeiro e compreende inúmeros tipos de materiais, desde expediente até os mais complexos equipamentos destinados à pesquisa.

Após a adesão ao Programa REUNI; a implantação e estruturação de novos campi e o redimensionamento dos campi existentes verificou-se um grande aumento na demanda por aquisição de bens e serviços comuns, acarretando com isso, um grande gargalo no setor de compras e consequentemente, excessiva morosidade na conclusão dos processos licitatórios. Esta demanda, em sua maioria, foi por aquisição de materiais e serviços comuns destinados ao redimensionamento dos campi existentes (Darcy Ribeiro e Planaltina), a estruturação dos novos campi (Ceilândia e Gama) e as demandas de rotina dos diversos centros de custos.

Nesse aspecto, estudos realizados por Rocha e Silva (2006), já apontavam para a morosidade na aquisição de bens e serviços no âmbito da FUB, argumentando que eram inúmeras as reclamações efetuadas por parte dos Centros de Custos. Os autores apontaram que não havia uma padronização dos procedimentos de compras, principalmente, na fase interna da preparação do procedimento. Nesse prisma, constataram que os pedidos de compras, geralmente eram elaborados sem o auxílio de um catálogo de materiais e serviços e que dessa forma, o trabalho dos Centros de Custos era dificultado quanto à caracterização do objeto a ser licitado. Verificaram ainda, a inexistência de um sistema de informações sobre compras que permitisse a uniformização e a racionalização das rotinas de compras e a ausência de um planejamento das compras, as quais eram realizadas apenas no volume de recursos disponíveis, sendo formalizadas quando se constatava a falta de material, ou seja, não havia uma estimativa ou previsão de demanda dos materiais, a fim de que se pudesse efetuar a compra de forma planejada.

Nesse contexto, havia a necessidade de se realizar uma análise criteriosa dos procedimentos adotados pelo setor de compras, com o intuito de buscar a racionalização das rotinas e a agilização dos processos, com o propósito de aumentar a celeridade, eficiência e eficácia da qualidade dos serviços prestados.

Tornando-se multicampi, a UnB agigantou-se no decorrer dos anos. Desta forma, sua estrutura de compras já não suportava mais o atendimento às suas demandas, principalmente, no que diz respeito à celeridade e eficácia dos processos. Era preciso urgentemente reformular a sua organização administrativa, a fim de proporcionar maior rigor no manejo dos recursos públicos. Diante disto, o DAF considerando a necessidade de disciplinar e uniformizar os procedimentos pertinentes às solicitações de compras de materiais 
de consumo, permanente, equipamentos e serviços, em julho de 2011 regulamentou normas, procedimentos e critérios para compras de bens e serviços no âmbito da FUB.

Posteriormente, em 2012, seguindo os moldes do Programa Nacional de Gestão Pública e Desburocratização, no intuito de proporcionar maior agilidade aos processos de compras, o DAF criou um procedimento de compra batizando-o de "Programa Estratégico de Compra Fácil" (uma espécie de agenda de compras), aplicando-o a cada semestre. Assim, todos os pedidos de compra deveriam previamente, ser encaminhados ao DAF dentro de um prazo pré-estabelecido.

O "Compra Fácil" passou a exigir também, que as unidades e órgãos vinculados à UnB, lançassem o detalhamento dos pedidos de compras no Sistema de Materiais da UnB (SIMAR). Passou-se então, a utilizar o Pregão em sua forma eletrônica, com o uso de um procedimento especial de licitação denominado de Sistema de Registro de Preços (SRP). Com isso, procurou-se evitar o fracionamento da despesa e proporcionar a diminuição do volume de compras por dispensa de licitação, modalidade rechaçada pelos órgãos de controle como Tribunal de Contas da União (TCU), Controladoria Geral da União (CGU) e Ministério Público da União (MPU).

Posteriormente, em 2013, com a intenção de possibilitar inovações em seu formato, o "Programa Estratégico de Compra Fácil" foi rebatizado com o nome de "Agenda de Compras". Segundo o DAF, o novo formato do programa permitiria uma melhor eficiência dos processos, possibilitando a otimização das compras em preço e qualidade, bem como a diminuição do prazo entre o pedido de compra e o seu recebimento, estabelecendo para tanto, apenas um cronograma de compras para todo o exercício.

Porém, estudos realizados por Campos (2013), afirmam que com a centralização das compras na Diretoria de Compras no Campus Darcy Ribeiro, os prazos para a preparação do procedimento licitatório extrapolam, sendo necessário por vezes, solicitar aos fornecedores novas propostas, o que prejudica a execução das atividades cotidianas devido ao retrabalho. $\mathrm{O}$ autor afirma ainda que mesmo com a pesquisa de mercado realizada, o termo de referência e o edital, outros processos encaminhados que exigem abertura de certame licitatório, levam tempo igual ou superior a 125 dias até a sua homologação.

Contudo, a Administração justifica que a adoção dessa nova sistemática de compras, reduz o volume de compras, permite melhor eficiência para os processos, emprega técnicas para selecionar as melhores alternativas com vistas à viabilização das compras em preço e qualidade e diminui, inclusive, o prazo entre o pedido de compra e o seu recebimento. 
No que tange a utilização do SRP, verifica-se que para determinados tipos de bens comuns, a UnB vem adotando o procedimento de compras por adesão às atas de registro de preços de outros órgãos federais, o que "para alguns estudiosos, constitui uma forma inteligente e vantajosa para ser utilizada pelos entes públicos" (GONÇALVES, 2013). Este procedimento, entretanto, vulgarizou-se sob a denominação de "carona", que se traduz em linguagem coloquial, a ideia de aproveitar o percurso que alguém está desenvolvendo para concluir o próprio trajeto, sem custos.

Em relação a essa prática, Justen Filho (2010, p. 207) fez a seguinte crítica: “A solução desbordou os limites da lei e produziu resultados teratológicos, especialmente porque propicia contratações ilimitadas com base em uma mesma e única licitação”.

Por outro lado, a suposta economicidade advinda do Pregão em detrimento das modalidades tradicionais, tem sido defendida apenas como expressão intuitiva das características de desenvolvimento do processo licitatório quando o mesmo é utilizado. O que se deduz é que em face da inversão de fase proporcionada pelo Pregão, ou seja, a primeira habilita os licitantes a participarem do certame e somente após esta fase iniciar-se-á a fase de lances sucessivos, as empresas com a finalidade de obterem uma contratação com a Administração Pública, tendem a reduzir suas margens de lucro exaustivamente, o que resultaria em um custo relativamente menor para o Governo.

Partindo desse pressuposto, poderiam concordar rapidamente, tanto os responsáveis pelos processos licitatórios na Administração Pública, quanto os que lidam com a venda e a prestação de serviços ao Governo. Contudo, ressalta-se que isto pode trazer um viés de mensuração já que esta análise não leva em conta a estratégia dos fornecedores nesse tipo de disputa, que geralmente, começam com o preço mais elevado para que, caso não exista forte concorrência, eles consigam licitar o seu produto por um preço mais alto (FARIA et al. 2011).

Quanto à otimização das compras retro mencionadas, verifica-se que a sistemática adotada, vem apresentando um excesso de formalismo por parte dos setores envolvidos com os processos licitatórios, contrariando assim, o seu objetivo inicial, cuja finalidade era de proporcionar celeridade às atividades administrativas na área de compras.

Desta forma, é possível inferir que em pleno século XXI, ainda exista profissionais que faz com que o jargão, "tempo é dinheiro", não tenha o significado ao qual expressa. Quando falamos em compras públicas logo imaginamos a morosidade, a burocracia e o sempre questionado "formalismo" como dificuldades para os possíveis fornecedores da máquina pública. Os governos mudam, mas os entraves das compras públicas continuam 
${ }^{1}$ inalterados. Os profissionais se alteram, mas suas mentalidades são impregnadas pelas más deixas do passado e suas inovações confrontam com seu despreparo, o qual ocasiona o termo mais usado pelos integrantes desse imbróglio processual, mais conhecido como burocracia ou porque não dizer "burrocracia" (TRINDADE, 2009).

Desde sua implantação, o Planejamento de Compras mencionado em linhas passadas vem sofrendo pequenas alterações. Em 2012, a proposta apresentou um Calendário de Compras $^{1}$ por semestre. Para 2013, o referido calendário foi reformulado sendo estabelecido para todo o exercício. Já em 2014, o calendário de compras foi divulgado com pequenas alterações nos prazos correspondentes as etapas dos procedimentos para o processamento dos pedidos de compras. No exercício de 2015, a proposta do referido calendário sofre novas modificações, dentre elas, a inclusão de equipes técnicas específicas das Unidades de Compras (DCO/PRC/BCE), para cada grupo de compras. Desta vez, não se vislumbra em que momento será elaborado o parecer pela PJU sobre a minuta, a publicação dos editais e a abertura dos certames licitatórios. Não estão definidos também, prazos para elaboração de atas de registro de preços e emissão de notas de empenhos.

Para a utilização da Agenda de Compras em 2015, foi elaborada uma Cartilha de Compras, na qual foram reunidas informações com a finalidade de orientar a comunidade universitária, e que segundo o DAF vem contribuindo significativamente para a melhoria dos processos de trabalho da Diretoria de Compras - DCO.

A Cartilha supracitada é composta por capítulos, os quais apresentam o Calendário de Compras e os prazos necessários para a demanda dos pedidos de compras; a descrição dos passos para a realização dos diferentes tipos de pedidos de compras; a documentação necessária para o seu ingresso nas Unidades de Compras bem como a abordagem sobre a legislação e comentários norteadores sobre processos de compras da Administração Pública Federal.

Nela, são detalhadas ainda as seguintes etapas para as aquisições/contratações:

$\checkmark \quad 1^{\text {a }}$ etapa: envio dos pedidos de compras nacionais e internacionais pelos Centros de Custos à Diretoria de Compras;

$\checkmark \quad 2^{\mathrm{a}}$ etapa: análise e consolidação dos pedidos de compras pela Diretoria de Compras;

$\checkmark \quad 3^{\text {a }}$ etapa: elaboração de editais pela Comissão de Licitação e envio à Procuradoria Jurídica para análise e parecer dos processos;

\footnotetext{
${ }^{1}$ Criado em 2012 com o nome de "Programa Estratégico de Compra Fácil”" (uma espécie de agenda de compras). Inicialmente, foi aplicado por semestre e posteriormente, rebatizado em 2012 com o nome de "Agenda de Compras", sendo utilizado para todo o exercício.
} 
$\checkmark \quad 4^{a}$ etapa: adequação, publicação de editais após análise da PJU e abertura de certame licitatório pela Comissão de Licitação e parecer dos Centros de Custos;

$\checkmark \quad 5^{\text {a }}$ etapa: elaboração de atas de registros de preços e assinatura de contratos;

$\checkmark \quad 6^{\text {a }}$ etapa: emissão de empenho e fases subsequentes.

Os documentos básicos que compõem os pedidos de compra são os seguintes:

a. Memorando de oficialização do pedido;

b. Formulário "Pedido de compra" registrado no sistema de material SIMAR;

c. Cotação de Preços: no mínimo três propostas de orçamento;

d. Cópia da nota de dotação orçamentária;

e. Termo de referência/projeto básico, para compras superiores a $\mathrm{R} \$ 8.000$ ou para a contratação de serviços, independentes de valor, conforme o caso.

Para todos os pedidos de compras encaminhados à Diretoria de Compras, deverá ser apresentada ainda, uma justificativa para a realização da despesa, requisito necessário e fundamental para viabilizar o atendimento à demanda, imposto pelos princípios norteadores da Administração Pública. A justificativa em questão consiste em fundamentar a realização da despesa na destinação que lhe será dada e nos resultados esperados, pois, toda aquisição deverá ser antecedida da avaliação da necessidade e utilidade do objeto adquirido, sob o prisma da eficácia.

O fluxo processual para as compras nacionais ocorrem de duas maneiras: Licitação e

\section{Dispensa ou Inexigibilidade de Licitação.}

Nos casos de Licitação, os processos serão atendidos por: pregão, carta convite, tomada de preço, concorrência nacional internacional. Nesses casos o fluxograma processual transcorrerá conforme a figura 5.

O trâmite processual para os processos de Licitação se dá da seguinte forma:

$1^{\circ}$ - Planejamento da Unidade Solicitante:

$\checkmark$ O Centro de Custo inicia o planejamento de seus pedidos para definição dos quantitativos e especificação dos bens e serviços necessários ao longo do exercício, e em seguida prepara toda a documentação para abertura do pedido de compras, enviando-a a Diretoria de Compras, onde deverá passar por uma análise prévia e só então, remetida ao DAF e Decanato de Planejamento e Orçamento - DPO, para homologação da despesa e detalhamento do crédito, respectivamente;

$2^{\circ}$ - Análise e Instrução da Diretoria de Compras:

$\checkmark$ A DCO recebe o pedido de compras fazendo um check-list da documentação encaminhada e sendo constatada alguma irregularidade, o processo é devolvido ao 
Centro de Custo para fins de adequação. Caso contrário, o mesmo segue para a Coordenação de Análise e Instrução Processual - CAIP ou para a Coordenação de Importação e Exportação - CIE, que realizará a análise de como o pedido será atendido e o devido enquadramento da modalidade de licitação a ser adotada;

$3^{\circ}$ - Deliberação do DAF:

$\checkmark$ Ao receber o processo o DAF autoriza ou indefere o pedido e, em caso positivo, o processo seguirá para a DPO para alocação do crédito, caso contrário, o mesmo é devolvido a DCO para as devidas adequações junto à Unidade Solicitante;

$4^{\circ}$ - Deliberação do DPO:

$\checkmark$ O DPO por sua vez, verificará a adequação orçamentária e, por meio da nota de dotação, realizará a alocação e o detalhamento do crédito;

$5^{\circ}$ - Elaboração da Minuta de edital pela Comissão de Licitação:

$\checkmark$ A Comissão de Licitação - COL recebe o processo do DPO e, após a autuação pela Coordenação de Compras - CCO ou CIE, para os casos de concorrência internacional, realiza as etapas de conferência da instrução do processo e elabora a minuta do edital, minuta de contrato (em caso de Prestação de Serviço) e a minuta de ata de registro de preços (em caso de Pregão para SRP). A COL instrui o processo com as normas básicas solicitadas pelos órgãos de controle e de acordo com as especificações do Termo de Referência, enviando-o em seguida à Procuradoria Jurídica - PJU para análise e parecer;

$6^{\circ}$ - Análise e parecer da PJU:

$\checkmark$ A PJU analisa as minutas de editais e/ou contratos, emitindo parecer favorável ou não, em conformidade com a legislação de licitações e de contratos. Nesse quesito, ressalta-se que de acordo com a legislação vigente, o prazo para esta finalidade é de 15 dias. No caso de parecer desfavorável, a COL irá avaliar e ajustar o processo para em seguida, retornar o processo à PJU para emissão de parecer conclusivo;

$7^{\circ}$ - Adequação e publicação de Edital pela COL:

$\checkmark$ Nesta fase, após parecer favorável da PJU, a COL irá coordenar e executar as atividades inerentes à licitação, como aviso de licitação, publicação, sessão pública, credenciamento de fornecedores, averiguação de documentação, esclarecimentos sobre as especificações, entre outros;

$8^{\circ}$ - Parecer da unidade solicitante:

$\checkmark$ Após a análise de toda a documentação e propostas dos fornecedores, será formulado um parecer discriminando todos os itens do objeto e seus respectivos fornecedores. 
Em seguida, o processo será encaminhado à unidade solicitante, para que a mesma avalie se as propostas apresentadas atendem as expectativas referentes ao preço e a qualidade. Tudo em conformidade, a unidade solicitante irá emitir um parecer favorável sinalizando a continuidade da licitação e, caso haja algum item que não atenda as expectativas, será elaborada uma justificativa pela unidade solicitante, para que seja realizado o chamamento da $2^{\mathrm{a}}$ colocada e assim sucessivamente, de forma que a licitação tenha esta etapa concluída quando todos os itens forem validados pela unidade solicitante;

$9^{\circ}$ - Validação e aceite das propostas e adjudicação do Pregão Eletrônico pela COL:

$\checkmark$ De posse do processo validado pela unidade solicitante, o pregoeiro cessará o site do COMPRASNET para fazer a validação e aceite das propostas. Em seguida a COL providenciará a elaboração dos contratos e/ou atas de registro de preço para posterior envio (via correio) à etapa de assinatura. Estando o contrato ou ata devidamente assinados, o pregoeiro faz a adjudicação no site do COMPRASNET, e envia os autos para o DFAF, onde se realiza a assinatura dos contratos e/ou atas;

$10^{\mathbf{a}}$ - Homologação e assinatura do DAF:

$\checkmark$ Nesta etapa, o processo é homologado pelo DAF no site do COMPRASNET.

$11^{\circ}$ - Aquisição do objeto pela CCO:

$\checkmark$ O processo depois de homologado retorna à COL o qual será repassado à CCO para aquisição do objeto. Para os casos de registro de preços, as atas serão publicadas no Diário Oficial da União - DOU e informado a data de vigência no sistema SIASG. Em se tratando de entrega imediata o processo será encaminhado à DCF para fins de emissão de empenho. Nos casos de contratos que geram obrigações futuras os processos serão enviados à $\mathrm{DCF}$ e retornam à $\mathrm{CCO}$ para publicação do contrato no SIASG. Para os casos de registros de preços, as atas serão enviadas às unidades solicitantes para formularem os pedidos de compra.

$12^{\circ}$ - Emissão de empenho pela DCF:

$\checkmark$ A DCF por meio da Coordenadoria de Execução Orçamentária - CEO registrará o comprometimento da despesa orçamentária com a emissão da Nota de Empenho - NE. De posse da NE, o fornecedor fará a entrega do material ou do serviço no prazo estabelecido no edital. Para os casos de importação, o processo inicia-se com a emissão do empenho. As fases seguintes são: classificação de mercadorias, conforme Normas de Classificação de Mercadorias - NCM e registro dos licenciamentos no Sistema Integrado de Comércio Exterior - SISCOMEX, contratação de câmbio e 
pagamento ao exportador, embarque das mercadorias e liberação alfandegária e entrega do bem à unidade solicitante.

$13^{\circ}$ - Notificação ao fornecedor pela COL:

$\checkmark$ Ao receber a NE a COL digitaliza-a e notifica os fornecedores. Logo após, a NE é encaminhada ao Almoxarifado Central e a unidade solicitante. Para a CIE, a notificação do exportador se dá com a contratação do câmbio quanto ao pagamento da importação e envio de instruções para o embarque das mercadorias.

$14^{\circ}$ - Recebimento do material pelo Almoxarifado Central ou Unidade:

$\checkmark$ O Almoxarifado Central recebe os materiais e efetua a distribuição às Unidades solicitantes, conforme procedimentos adotados pelo DAF.

$15^{\circ}$ - Baixa e liquidação da Nota Fiscal pela CCO:

$\checkmark$ A CCO processa a baixa das notas fiscais confrontando a nota fiscal com o número do processo e empenho e, em seguida, faz-se a conferência dos seguintes documentos: Declaração do Simples Nacional; atesto de recebimento; dados bancários do fornecedor e nota de entrada do material. Após este procedimento, inicia-se a liquidação no processo e no sistema SIMAR.

$16^{\circ}$ - Pagamento aos fornecedores pela DCF:

$\checkmark$ A DCF realiza a conferência dos documentos, liquida as notas fiscais e realiza o pagamento. Nos processos de importação, o pagamento ocorre na contratação do câmbio.

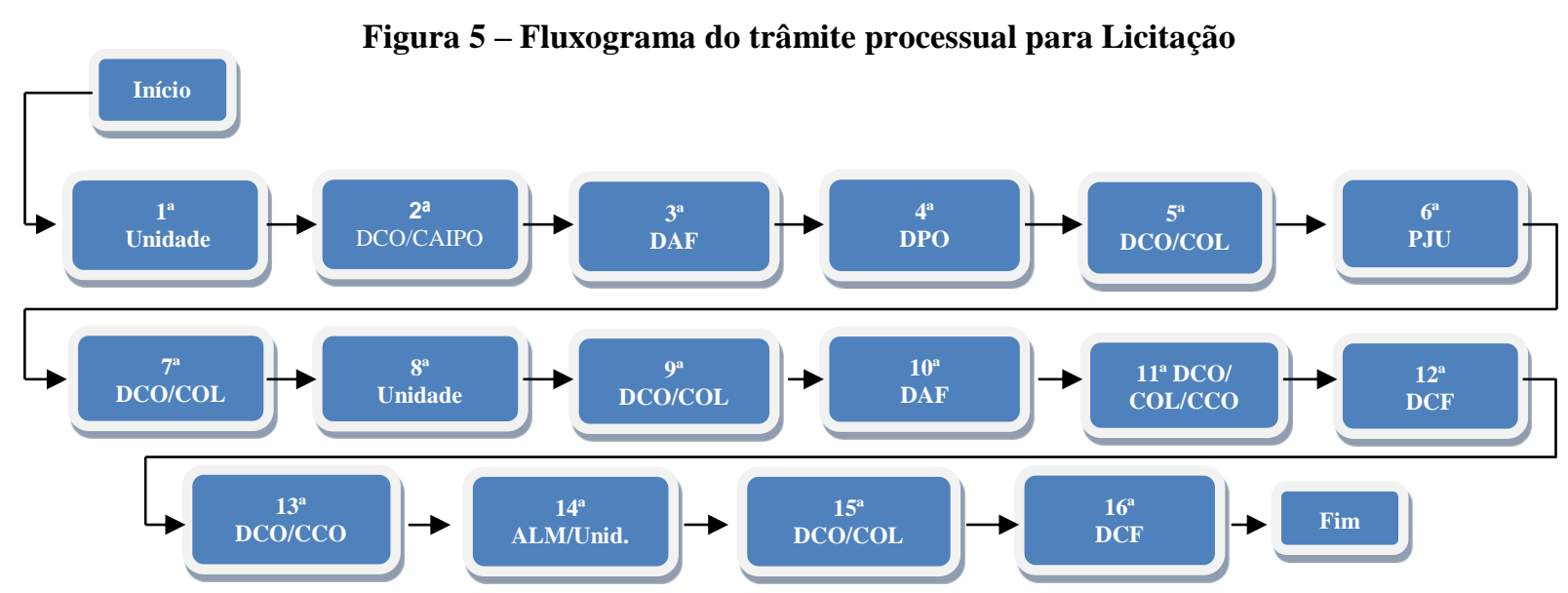

Fonte: DAF/DCO/Cartilha de Compras (adaptada).

Para os processos com Dispensa de Licitação, os mesmos serão atendidos por: dispensa ou inexigibilidade de licitação e por adesões às atas de registros de preços. Quando houver obrigações futuras ou configurar serviços continuados, os processos serão apreciados 
pela PJU. O fluxograma segue os mesmos passos da licitação com exceção das etapas 6 a 10 (Figura 6):

Figura 6 - Fluxograma do trâmite processual para Dispensa de Licitação.

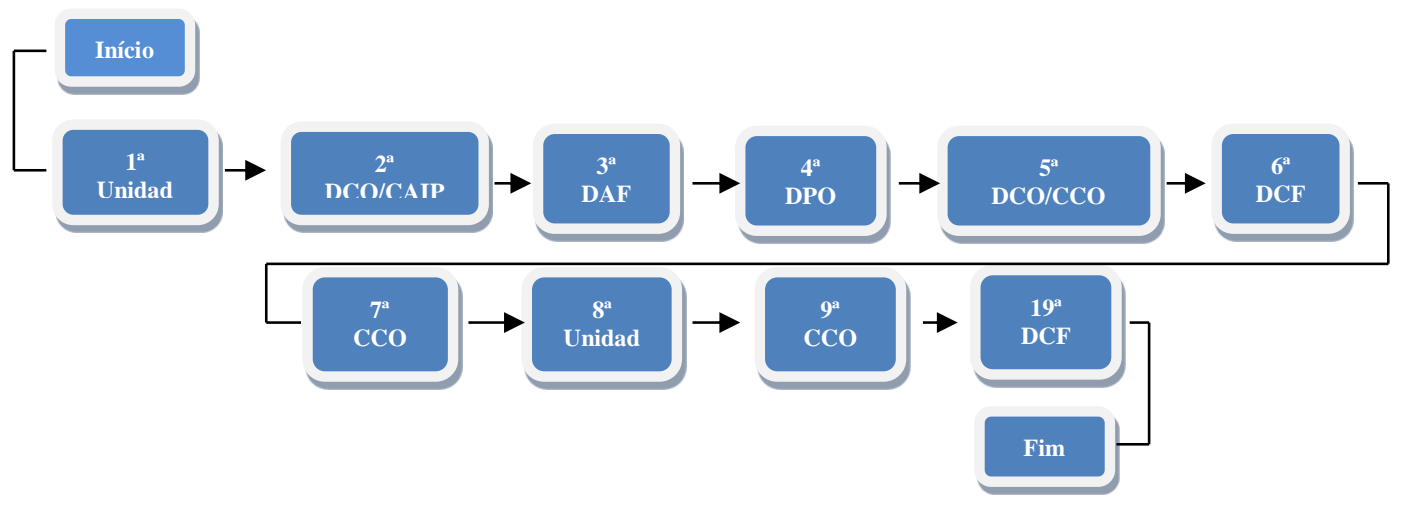

Fonte: DAF/DCO/Cartilha de Compras (adaptada).

Para os casos de compras internacionais, o fluxograma ocorre de acordo com a figura 7 e a partir da $8^{\circ}$ etapa a CIE realiza os seguintes procedimentos:

$\checkmark$ Classificação das mercadorias de acordo com NCM;

$\checkmark$ Registro de Licenciamento;

$\checkmark$ Contratação cambial e pagamento ao exportador;

$\checkmark$ Instruções e acompanhamento de embarque;

$\checkmark$ Registro de Declaração de Importação - DI no SISCOMEX;

$\checkmark$ Liberação alfandegária;

$\checkmark$ Entrega das mercadorias ao interessado.

Figura 7 - Fluxograma resumido do trâmite processual para compras internacionais

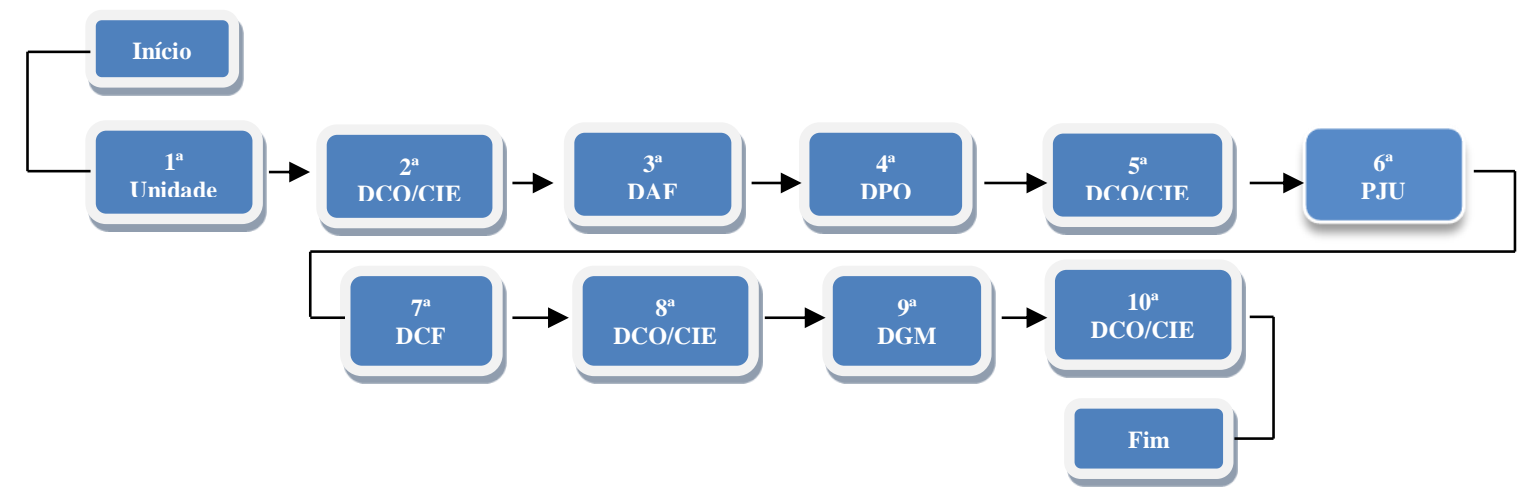

Fonte: DAF/DCO/Cartilha de Compras 2015 (adaptada).

$\mathrm{Na}$ Cartilha de Compras de 2015, os materiais a serem adquiridos foram agrupados conforme o quadro 3. 
Quadro 3 - Unidades de Compra e Grupos de materiais.

\begin{tabular}{|c|c|}
\hline UNIDADE DE COMPRA & DCO \\
\hline Grupo de material & Especificação \\
\hline $\begin{array}{l}\text { Material de escritório, expediente, mobiliário, } \\
\text { eletrodomésticos e eletrônicos (Exceto TI) }\end{array}$ & $\begin{array}{c}\text { Lápis, lapiseira, caneta, grampeador, papéis, materiais } \\
\text { de higiene e limpeza, mesa, cadeira, armário, televisão, } \\
\text { micro-ondas, geladeira, telefone, etc. }\end{array}$ \\
\hline $\begin{array}{l}\text { Equipamentos e insumos para áudio, vídeo e } \\
\text { refrigeração. }\end{array}$ & $\begin{array}{l}\text { Projetor de multimídia, aparelho de som, DVD, caixa } \\
\text { acústica, condicionador de ar, exaustor, equipamentos } \\
\text { de vigilância e segurança, etc. }\end{array}$ \\
\hline Equipamentos e insumos de informática. & $\begin{array}{l}\text { Placa de vídeo, processador, memória, HD, pen drive, } \\
\text { mouse, teclado, cartuchos de tinta, computadores, } \\
\text { notebooks, impressoras, softwares, equipamentos de } \\
\text { soluções de TI, telefones, centrais telefônicas, etc. }\end{array}$ \\
\hline Materiais de laboratório/hospitalar. & Luvas, agulhas, reagentes, vidrarias, etc. \\
\hline Equipamentos de laboratório. & Balança digital, microscópio, estufa, etc. \\
\hline Eventos comemorativos e de projetos. & $\begin{array}{l}\text { Locação de equipamentos, coffee break, contratação de } \\
\text { segurança, manobrista, locação de espaço físico, etc. }\end{array}$ \\
\hline Vestibulares, concursos e afins. & Processos seletivos em geral, PAS, vestibular EAD, etc. \\
\hline Serviços gráficos. & Cópias, livros, revistas, panfletos, etc. \\
\hline Outros materiais. & $\begin{array}{c}\text { Peças e recargas de extintores, uniformes, equipamentos } \\
\text { de EPI, bandeiras, etc. }\end{array}$ \\
\hline Outros serviços. & $\begin{array}{c}\text { Contratação de serviços de plotagem e reformas de } \\
\text { mobiliário. }\end{array}$ \\
\hline UNIDADE DE COMPRA & PRC \\
\hline Grupo de material & Especificação \\
\hline Material hidráulico/elétrico. & $\begin{array}{c}\text { Componentes de sistema de abastecimento de água, } \\
\text { energia e refrigeração. }\end{array}$ \\
\hline $\begin{array}{l}\text { Aquisição de material de consumo específico para } \\
\text { atividades de restauração e processamento técnico. }\end{array}$ & $\begin{array}{c}\text { Papel japonês, papel marmorizado, cola específica, } \\
\text { couro, etc. }\end{array}$ \\
\hline Insumos para redes de dados. & Fios, cabos, terminais, caixas de luz, etc. \\
\hline Materiais de construção. & $\begin{array}{c}\text { Alvenaria, marcenaria, ferramentaria, pintura, } \\
\text { carpintaria e serralheria para manutenção de pátios, } \\
\text { parques e jardins, etc. }\end{array}$ \\
\hline Serviços de segurança. & Instalação de câmeras, entre outros. \\
\hline Manutenção automotiva. & $\begin{array}{l}\text { Manutenção de veículos, aquisição de combustíveis, } \\
\text { aquisição de pneus, peças, revisão preventiva e } \\
\text { contratação de serviços necessários à manutenção de } \\
\text { veículos pertencentes à frota da FUB. }\end{array}$ \\
\hline Manutenção de máquinas e equipamentos. & $\begin{array}{l}\text { Manutenção de equipamentos de informática e } \\
\text { maquinário em geral. }\end{array}$ \\
\hline $\begin{array}{l}\text { Aquisição/locação de veículos, máquinas e } \\
\text { equipamentos. }\end{array}$ & $\begin{array}{l}\text { Aquisição de veículos, locação de serviços de } \\
\text { transporte, entre outros. }\end{array}$ \\
\hline Serviços de descarte e coleta de resíduos. & $\begin{array}{c}\text { Contratação de serviços para o descarte de lâmpadas, } \\
\text { coleta e destinação final de resíduos químicos e } \\
\text { biológicos, etc. }\end{array}$ \\
\hline $\begin{array}{l}\text { Aquisição de material de consumo para } \\
\text { acondicionamento de resíduos em geral. }\end{array}$ & Containers, etc. \\
\hline UNIDADE COMPRA & $\mathrm{BCE}$ \\
\hline Grupo de material & Especificação \\
\hline $\begin{array}{c}\text { Aquisição de insumos para utilização em serviços } \\
\text { específicos de restauração e tratamento de material } \\
\text { bibliográfico. }\end{array}$ & $\begin{array}{l}\text { Equipamentos de restauração, máquina de sucção, } \\
\text { obturadora de papéis, mesa douradora digital de couros, } \\
\text { etc. }\end{array}$ \\
\hline $\begin{array}{l}\text { Aquisição de material de consumo específico para } \\
\text { atividades de restauração e processamento técnico. }\end{array}$ & $\begin{array}{l}\text { Papel japonês, papel marmorizado, cola específica, } \\
\text { couro, etc. }\end{array}$ \\
\hline
\end{tabular}




\section{UNIDADE DE COMPRA}

Aquisição de mobiliário e arquivos específicos para armazenamento de material bibliográfico.

Contratação de serviços específicos de gestão e Estante de livros, arquivos deslizantes, mapoteca, etc. tratamento técnico de acervo bibliográfico.

Contratação de serviços para assinatura e renovação de base de dados e periódicos. Projeto para catalogação, classificação, etiquetagem, restauração de material bibliográfico, etc. Assinatura de periódicos científicos, periódicos correntes, revistas eletrônicas e impressas, bases de dados, etc.

Contratação de serviços de segurança, preservação e controle de acervo bibliográfico.

Monitoramento por rádio frequência e câmeras; equipamentos de autoempréstimo e devolução, etc.

Mesa higienizadora de materiais bibliográficos,

Locação de máquinas e equipamentos específicos para gestão e tratamento de acervo bibliográfico. equipamento para conversão de códigos de barras comuns em etiquetas para leitura por rádio frequência, etc.

Aquisição de material bibliográfico nacional e estrangeiro.

Compras das indicações de bibliografias básicas e complementares dos cursos, bibliografias de projetos e demais itens selecionados. 


\section{PROCESSO METODOLÓGICO}

Este capítulo tem por objetivo descrever o método e o procedimento adotados na pesquisa, e, para tanto, foi subdividido em seções. Primeiramente será apresentada a descrição da pesquisa. Em seguida, a estratégia para análise dos dados quantitativos e logo após, a apresentação e análise dos resultados.

\subsection{Descrição da pesquisa}

Segundo Vergara (2005), existem diversas taxonomias de pesquisa que variam conforme os critérios utilizados na categorização. Essa autora sugere duas formas de classificação: quanto aos fins e quanto aos meios. De maneira semelhante, Gil (2002) apresenta dois critérios de classificação, sendo um baseado nos objetivos gerais do estudo, e o outro, com base nos procedimentos técnicos adotados.

Assim, de acordo com a classificação sugerida por Vergara (2005), quanto aos fins, esta pesquisa caracteriza-se como descritiva. Para ele as pesquisas descritivas têm como objetivo, a descrição das características de determinada população ou fenômeno, podendo ainda estabelecer correlações entre variáveis e definir sua natureza.

Quanto aos meios de investigação, caracteriza-se como estudo de caso com uma abordagem quantitativa, sendo realizada uma análise descritiva dos dados obtidos com base em levantamento documental e eletrônico, realizado nos processos licitatórios ocorridos no período de 2011 a 2012.

\subsection{Estratégia para Análise dos Dados Quantitativos}

Como estratégia da análise dos dados, optou-se pela utilização do software Statistical Package for the Social Sciences (SPSS). Os dados analisados foram extraídos da base de dados do Portal de compras eletrônicas do Governo Federal - COMPRASNET bem como aqueles disponibilizados nos processos de compras arquivados na Diretoria de Compras da UnB, organizados em 21 grupos, destinados à aquisição de material e a prestação de serviços.

\subsection{Apresentação e análise dos resultados}

Inicialmente, foi efetuado o levantamento dos dados extraídos de 79 pregões realizados em 2011 e 81 pregões realizados em 2012, na situação de homologados, 
totalizando 160 pregões nos dois períodos. Os produtos desses pregões foram consolidados em grupos, levando-se em consideração o gênero de bens e serviços comuns existentes nos dois períodos, perfazendo o total de 21 grupos.

Contudo, para a análise dos dados, 9 pregões pertencentes a 6 grupos distintos, foram descartados por serem homologados apenas em um dos exercícios (2011 ou 2012). Dessa forma, restaram apenas 15 grupos de bens e serviços para serem analisados, correspondentes ao total de 151 pregões, compreendidos nos dois períodos.

Os grupos foram compostos por determinados tipos de materiais (subgrupos) e apresentaram as seguintes denominações: gêneros alimentícios; material de laboratório/hospitalar; material de expediente/mobiliário/limpeza; material de construção; materiais de consumo diversos; equipamentos diversos; material de esporte/ginástica; equipamentos, insumos de informática/áudio; máquinas/equipamentos e insumos agrícolas; instrumentos musicais; serviços gráficos; manutenção automotiva; serviços de teleconferência e vídeo-aulas e serviços diversos de pessoa jurídica.

Para a análise em questão, esses grupos foram apoiados num conjunto que contemplou as seguintes variáveis: valor estimativo inicial do processo; valor total homologado da licitação; total de licitantes no certame; total de licitantes vencedores no certame; total de itens a licitados; total de itens adjudicados; tempo da fase interna (em dias corridos); tempo da fase externa (em dias corridos) e tempo total da licitação (em dias corridos).

No tocante a análise dos dados foi utilizada a medida das correlações não paramétricas de postos de Spearman, normalmente denominada pela grega $\boldsymbol{\rho}$ (rho), a qual avalia uma função monótona arbitrária que pode ser a descrição da relação entre duas variáveis, sem fazer nenhumas suposições sobre a distribuição de frequências das variáveis.

A tabela 1 apresenta os coeficientes de correlação de postos de Spearman's. Nela, vislumbra-se de modo geral, uma significância positiva no coeficiente de correlação entre todas as variáveis analisadas. 
Tabela 1 - Coeficiente de correlação de postos de Spearman's

\begin{tabular}{|c|c|c|c|c|c|c|c|c|c|c|c|}
\hline & & & $\begin{array}{c}\text { QTD. DE } \\
\text { ITENS } \\
\text { LICITADOS }\end{array}$ & $\begin{array}{l}\text { QTD. DE ITENS } \\
\text { ADJUDICADOS }\end{array}$ & $\begin{array}{c}\text { FASE } \\
\text { INTERNA } \\
\quad(\text { dias } \\
\text { corridos })\end{array}$ & $\begin{array}{c}\text { FASE } \\
\text { EXTERNA } \\
\text { (dias } \\
\text { corridos) }\end{array}$ & $\begin{array}{c}\text { TEMPO } \\
\text { TOTAL DA } \\
\text { LICITAÇÃO } \\
\text { (dias corridos) }\end{array}$ & $\begin{array}{c}\mathbf{N}^{\circ} \mathrm{DE} \\
\text { LICITANTES } \\
\text { NO } \\
\text { CERTAME }\end{array}$ & $\begin{array}{c}\mathbf{N}^{\circ} \text { DE } \\
\text { LICITANTES } \\
\text { VENCEDORES } \\
\text { NO CERTAME }\end{array}$ & $\begin{array}{c}\text { VALOR } \\
\text { ESTIMADO } \\
\text { DO } \\
\text { PROCESSO }\end{array}$ & $\begin{array}{c}\text { VALOR } \\
\text { TOTAL } \\
\text { HOMOLO } \\
\text { GADO }\end{array}$ \\
\hline & $\begin{array}{l}\text { QTD. DE } \\
\text { ITENS } \\
\text { LICITADOS }\end{array}$ & $\begin{array}{l}\text { Correlati } \\
\text { on } \\
\text { Coefficie } \\
\text { nt }\end{array}$ & 1,000 &, $998^{* *}$ &, $575^{* *}$ &, $726^{* *}$ &, $679^{* *}$ &, $823^{* *}$ & ,957** &, $636^{* *}$ &, $630^{* * *}$ \\
\hline & & $\begin{array}{l}\text { Sig. (2- } \\
\text { tailed) }\end{array}$ & 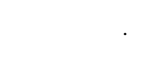 & ,000 & ,001 & ,000 & ,000 & ,000 & ,000 & ,000 &, 000 \\
\hline & QTD. DE & $\begin{array}{l}\mathrm{N} \\
\text { Correlati }\end{array}$ & 30 & 30 & 30 & 30 & 30 & 30 & 30 & 30 & 30 \\
\hline & $\begin{array}{l}\text { ITENS } \\
\text { ADJUDICAD } \\
\text { OS }\end{array}$ & $\begin{array}{l}\text { on } \\
\text { Coefficie } \\
\text { nt }\end{array}$ &, $998^{* *}$ & 1,000 &, $594^{* *}$ &, $739^{* *}$ & ,696 &, $826^{* *}$ &, $958^{* * *}$ &, $647^{* *}$ &, $641^{* *}$ \\
\hline & & $\begin{array}{l}\text { Sig. (2- } \\
\text { tailed) }\end{array}$ & ,000 & . & ,001 & ,000 & ,000 & ,000 & ,000 & ,000 &, 000 \\
\hline & & $\mathrm{N}$ & 30 & 30 & 30 & 30 & 30 & 30 & 30 & 30 & 30 \\
\hline & $\begin{array}{l}\text { FASE } \\
\text { INTERNA } \\
\text { (dias } \\
\text { corridos) }\end{array}$ & $\begin{array}{l}\text { Correlati } \\
\text { on } \\
\text { Coefficie } \\
\text { nt }\end{array}$ &, $575^{* *}$ &, $594^{* *}$ & 1,000 &, $736^{* *}$ &, $948^{* *}$ &, $770^{* *}$ &, $691^{* *}$ &, $589^{* *}$ &, $560^{* *}$ \\
\hline & & $\begin{array}{l}\text { Sig. (2- } \\
\text { tailed) }\end{array}$ & ,001 & ,001 & . & ,000 & ,000 & ,000 & ,000 & ,001 & ,001 \\
\hline & FASE & $\begin{array}{l}\mathrm{N} \\
\text { Correlati }\end{array}$ & 30 & 30 & 30 & 30 & 30 & 30 & 30 & 30 & 30 \\
\hline & $\begin{array}{l}\text { EXTERNA } \\
\text { (dias } \\
\text { corridos) }\end{array}$ & $\begin{array}{l}\text { on } \\
\text { Coefficie } \\
\text { nt }\end{array}$ &, $726^{* *}$ &, $739^{* *}$ &, $736^{* *}$ & 1,000 &, $891^{* *}$ &, $808^{* *}$ &, $809^{* * *}$ &, $623^{* *}$ &, $600^{* *}$ \\
\hline p & & $\begin{array}{l}\text { Sig. (2- } \\
\text { tailed) }\end{array}$ & ,000 & ,000 & ,000 & . & ,000 & ,000 & ,000 & ,000 & ,000 \\
\hline a & TEMPO & $\begin{array}{l}\mathrm{N} \\
\text { Correlati }\end{array}$ & 30 & 30 & 30 & 30 & 30 & 30 & 30 & 30 & 30 \\
\hline m & $\begin{array}{l}\text { TOTALDA } \\
\text { LICITAÇÃO } \\
\text { (dias }\end{array}$ & $\begin{array}{l}\text { on } \\
\text { Coefficie } \\
\text { nt }\end{array}$ &, $679^{* *}$ &, $696^{* *}$ &, $948^{* *}$ &, $891^{* *}$ & 1,000 &, $848^{* *}$ &, $786^{* *}$ &, $666^{* *}$ &, $632^{* * *}$ \\
\hline , & corridos) & $\begin{array}{l}\text { Sig. (2- } \\
\text { tailed) }\end{array}$ & ,000 & ,000 & ,000 & ,000 & . & ,000 & ,000 & ,000 & ,000 \\
\hline $\mathrm{s}$ & $\mathrm{N}^{\circ} \mathrm{DE}$ & $\begin{array}{l}\mathrm{N} \\
\text { Correlati }\end{array}$ & 30 & 30 & 30 & 30 & 30 & 30 & 30 & 30 & 30 \\
\hline $\begin{array}{l}\mathbf{r} \\
\mathbf{h} \\
\mathbf{o}\end{array}$ & $\begin{array}{l}\text { LICITANTES } \\
\text { NO } \\
\text { CERTAME }\end{array}$ & $\begin{array}{l}\text { on } \\
\text { Coefficie } \\
\text { nt }\end{array}$ &, $823^{* * *}$ &, $826^{* *}$ &, $770^{* *}$ &, $808^{* *}$ &, $848^{* *}$ & 1,000 &, $912^{* *}$ &, $741^{* *}$ &, $726^{* *}$ \\
\hline & & $\begin{array}{l}\text { Sig. (2- } \\
\text { tailed) }\end{array}$ & ,000 & ,000 & ,000 & ,000 & ,000 & . & ,000 & ,000 & ,000 \\
\hline & $\mathrm{N}^{\circ} \mathrm{DE}$ & $\begin{array}{l}\mathrm{N} \\
\text { Correlati }\end{array}$ & 30 & 30 & 30 & 30 & 30 & 30 & 30 & 30 & 30 \\
\hline & $\begin{array}{l}\text { LICITANTES } \\
\text { VENCEDORE } \\
\text { S NO }\end{array}$ & $\begin{array}{l}\text { on } \\
\text { Coefficie } \\
\text { nt }\end{array}$ &, $957^{* *}$ &, $958^{* * *}$ & ,691* &, $809^{* *}$ &, $786^{* *}$ &, $912^{* *}$ & 1,000 &, $673^{* *}$ & , $667^{* *}$ \\
\hline & CERTAME & $\begin{array}{l}\text { Sig. (2- } \\
\text { tailed) }\end{array}$ & ,000 & ,000 & ,000 & ,000 & ,000 & ,000 & . & ,000 & ,000 \\
\hline & VALOR & $\begin{array}{l}\mathrm{N} \\
\text { Correlati }\end{array}$ & 30 & 30 & 30 & 30 & 30 & 30 & 30 & 30 & 30 \\
\hline & $\begin{array}{l}\text { ESTIMADO } \\
\text { DO } \\
\text { PROCESSO }\end{array}$ & $\begin{array}{l}\text { on } \\
\text { Coefficie } \\
\text { nt }\end{array}$ &, $636^{* *}$ &, $647^{* * *}$ &, $589^{* * *}$ &, $623^{* * *}$ &, $666^{* *}$ &, $741^{* *}$ &, $673^{* *}$ & 1,000 &, $985^{* *}$ \\
\hline & & $\begin{array}{l}\text { Sig. (2- } \\
\text { tailed) }\end{array}$ & ,000 & ,000 & ,001 & ,000 & ,000 & ,000 & ,000 & . &, 000 \\
\hline & VALOR & $\begin{array}{l}\mathrm{N} \\
\text { Correlati }\end{array}$ & 30 & 30 & 30 & 30 & 30 & 30 & 30 & 30 & 30 \\
\hline & $\begin{array}{l}\text { TOTAL } \\
\text { HOMOLOGA } \\
\text { DO }\end{array}$ & $\begin{array}{l}\text { on } \\
\text { Coefficie } \\
\text { nt }\end{array}$ &, $630^{* *}$ &, $641^{* *}$ &, $560^{* *}$ &, $600^{* *}$ & ,632** &, $726^{* *}$ & $667^{* * *}$ &, $985^{* *}$ & 1,000 \\
\hline & & $\begin{array}{l}\text { Sig. (2- } \\
\text { tailed) }\end{array}$ & ,000 & ,000 & ,001 & ,000 & ,000 & ,000 & ,000 & ,000 & \\
\hline & & $\mathrm{N}$ & 30 & 30 & 30 & 30 & 30 & 30 & 30 & 30 & 30 \\
\hline
\end{tabular}

Fonte: $\mathrm{O}$ autor.

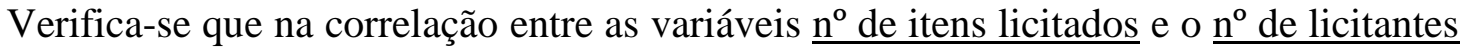
no certame, quanto maior $\mathrm{o} \mathrm{n}^{\mathrm{o}}$ de itens licitados, maior a incidência do $\mathrm{n}^{\mathrm{o}}$ de licitantes participantes no certame. Ou seja, nesta correlação, os fornecedores vislumbraram a possibilidade de atingir o maior lucro possível em função da quantidade e valor dos objetos 
licitados, o que proporcionou maior acirramento da disputa. Contudo, para Cox et al. apud Carter e Stevens (2006), o número de licitantes é tomado como exógeno e, nesse sentido, há poucas informações sobre os incentivos necessários à participação adequada dos licitantes nos leilões.

Evidencia-se na tabela em análise, a correlação de significância positiva entre as variáveis fase interna e o tempo total da licitação. Inicialmente, cabe salientar que nesta análise não faz sentido a existência de uma correlação positiva ou negativa, uma vez que a fase interna foi a que apresentou menor significância estatística (apesar de ser significante).

Contudo, a fase interna do procedimento licitatório, representa a etapa crucial do pregão para obter, posteriormente, os preços mais competitivos. Nela, segundo Oura et al. (2012), é elaborado um termo de referência, documento balizador da licitação, a partir do qual será redigido o edital e a minuta do contrato. É nesse documento que constará o valor estimado (resultado de simples média aritmética) do objeto a ser licitado, obtido pelas diversas áreas demandantes da Universidade, por meio de pesquisa de mercado junto aos diversos fornecedores.

Entretanto, no atual planejamento de compras da UnB, essa fase processual ainda ocorre de maneira manual, sem a utilização de qualquer tipo de sistema de gerenciamento dos preços orçados no passado ou monitoramento do ambiente externo. Desta forma, a ausência do gerenciamento dos preços orçados e o monitoramento do ambiente externo, pode propiciar um aumento da percepção oportunista por parte dos agentes envolvidos nos processos de licitação quando da realização do pregão, o que poderia ocasionar a elevação dos custos de transação.

Todavia, convém esclarecer que as pesquisas de preços iniciais, anteriores à licitação, são realizadas apenas para cumprir dispositivo legal previsto em Lei e para reservar o recurso que será dispendido posteriormente, e que desta forma, podem estar enviesadas e conduzir a interpretações equivocadas de seus resultados.

Por outro lado, em consonância com essa percepção, Oura et al. (2012), asseguram que esta exigência é um tanto controversa, na medida em que não há segurança de que os preços providos pelos fornecedores sejam os mesmos praticados em suas operações cotidianas e que desta forma, podem onerar substancialmente os valores nesta fase da licitação, a fim de auferir lucros adicionais na futura licitação.

Com a finalidade de se efetuar uma análise mais objetiva da correlação entre as variáveis supracitadas, que possibilite uma avaliação da performance do setor responsável pelas compras da UnB, os dados indicaram que a fase interna chegou a consumir cerca de 
74\% em média, do tempo total gasto na instrução processual do certame, ou seja, bem mais da metade do tempo de licitação é gasto na preparação do certame do que propriamente no procedimento em si. Desta maneira, este não seria o resultado esperado, uma vez que uma das características do pregão é a celeridade na elaboração dos procedimentos licitatórios com vistas a aquisição de bens e serviços comuns.

Analisando alguns processos com intuito de verificar possíveis explicações para a afirmação supracitada, verificou-se que parte significativa do tempo é dispensada na adequação das especificações do objeto às análises efetuadas pelos diversos setores envolvidos: unidades demandantes que elaboraram os pedidos de compras; termos de referência para os objetos, setor que elaborou o edital, procuradoria jurídica e pregoeiro.

Em relação à especificação adequada do objeto por parte dos demandantes, cabe esclarecer que nos meses iniciais do calendário de compras, grande parte desses demandantes encontra-se em período férias. Assim, considerando a ausência de informações por parte dos mesmos, e tendo em vista a racionalidade limitada do servidor responsável pelo processamento dos pedidos de compras da unidade, a qual impossibilita uma especificação adequada do objeto a ser licitado, não é possível elaborar e enviar a relação de todos os pedidos de compra da unidade dentro dos prazos pré-estabelecidos pelo calendário de compras. Dessa maneira, Breitenbach et al. (2009) afirmam que a existência da racionalidade limitada provoca, consequentemente, a incapacidade de coletar e processar todas as informações necessárias à elaboração de contratos completos, o que implica em condições necessárias para o surgimento de custos de transação.

Neste caso, os custos de transação mais uma vez podem surgir em função de ações oportunistas, tendo em vista que as mesmas poderão ser postas em prática pelos participantes de um processo de licitação, caso os órgãos públicos não especifiquem de forma completa e adequada o objeto licitado. Como consequência, estas ações oportunistas poderão incorrer em cotações de produtos de qualidade duvidosa por parte dos fornecedores, as quais ficarão restritas somente ao critério de menor preço.

Quanto a correlação de significância positiva entre as variáveis fase externa e o tempo total da licitação, poucos são os momentos em que o procedimento teve interrupções como: impugnações, adiamento da licitação, alteração de edital, entre outros. Nesse prisma, os dados revelaram que a fase externa chegou a consumir em média $26 \%$ do tempo total gasto na licitação. Esse prazo pode ser caracterizado como dentro dos padrões estabelecidos para a realização do Pregão, pois nessa etapa há de se esperar o tempo entre o aviso e a abertura do 
procedimento, o prazo para impugnação do edital, o prazo recursal (quando houver), parecer da unidade demandante, envio das atas pelos fornecedores e a homologação do processo pela autoridade competente da instituição.

Convém destacar que na análise de correlação de Spearman, as variáveis $\underline{n^{\circ} \text { de }}$

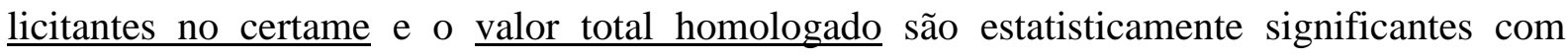
correlação positiva, ou seja, esta situação demonstra que houve aumento do valor total homologado em relação ao aumento do $\mathrm{n}^{\mathrm{o}}$ de licitantes participantes no certame. Um dos objetivos propostos com a criação do atual planejamento de compras na UnB, seria a busca pela redução dos preços praticados por pregões. No entanto, observa-se que esta situação, ocorreu de maneira oposta o que a teoria dos leilões afirma. Nesta situação, quanto maior a quantidade de participantes nos processos de compras, maior deveria ser a disputa e, com isso, maior deveria ser a probabilidade de que pudesse haver uma redução dos preços.

Sobre este aspecto, Carter e Stevens (2006), avaliam que embora vários estudos tenham sugerido que leilões reversos possam levar a redução de preços para os compradores, eles também têm indicado que os leilões reversos podem resultar em aumento da percepção de oportunismo por parte do comprador. Nessa linha de raciocínio, a correlação de significância positiva observada nas variáveis supracitadas, aponta para o indício de elevação dos custos de transação, decorrentes de ações oportunistas por parte dos agentes econômicos, as quais resultaram na elevação do valor total homologado nos pregões analisados. Nesse sentido, Santos (2007) avalia o oportunismo como sendo sinônimo de um comportamento aético que eleva os custos de transação, uma vez que os agentes econômicos visam aumentar benefícios próprios em detrimento dos demais.

Somando-se a isto, Diniz et al. (2004) acrescentam ainda que esse comportamento aético pode advir da incompletude dos contratos, gerando perdas para uma das partes envolvidas. Em relação a exposição desses autores, percebe-se que uma possível limitação de informações especificadas no edital de compras pelo agente comprador, poderia ter-se associada ao pressuposto da racionalidade limitada, e que dessa forma, teria dado abertura ao comportamento oportunista por parte do fornecedor.

Corroborando com esta afirmativa, Faria et al. apud Tridapalli e Beronelli (2015) asseveram que no caso das licitações, os participantes agem de forma oportunista quando órgãos públicos não especificam de forma completa o produto licitado. Desta forma, poderão se aproveitar desta incompletude para cotar produtos de pior qualidade ou que não atendam as necessidades do comprador. 
Nessa ótica, Porter e Zona apud Tridapalli e Beronelli (2015), sustentam que existem armadilhas nas compras por leilão que, dependendo das circunstância, podem torná-las muito vulneráveis à colusão e impedir a entrada de outros concorrentes e que desta forma, os benefícios dos leilões podem ser reduzidos se não forem eliminados os fatores que permitem o conluio do mercado.

Na prática, as lacunas decorrentes da incompletude dos contratos que podem permitir o oportunismo, por ocasião da realização dos leilões, são as especificações falhas do bem a ser licitado, a ausência de previsão de garantias, especificações inadequadas do objeto (o tipo de material, por exemplo), ou ainda, a imprevisibilidade do prazo de validade de produtos alimentícios ou medicinais. Assim, para evitar tais ações, cabe ao setor de compras da instituição, a elaboração de um edital o mais completo possível em sua totalidade, uma vez que quanto mais próximo da completude, menor será a possibilidade de incidência de atitudes oportunistas.

Nesse contexto, Wolfstetter apud Silva (2007) asseveram que a eficiência do leilão dependerá da existência de mecanismos e regras específicas que aumentem sua atratividade e reduza as possibilidades de conchavos, competição predatória e outras formas de poder de mercado.

Outro ponto extremamente relevante é a correlação entre as variáveis valor estimado $\underline{\text { do processo }}$ e o valor total homologado. Nesta correlação o valor total homologado foi maior que o valor estimado do processo. Nesta situação, o valor total homologado não deveria aumentar, uma vez que a instituição já tinha definido o valor máximo (estimativa de preços, por exemplo) que estaria disposta a pagar pelo bem ou serviço leiloado. Neste caso, cabe salientar que em consonância com o princípio que originou - a eficiência -, o pregão possibilita à Administração Pública a obtenção de preços muito inferiores aos de mercado. Corrobora-se com esta afirmativa, estudos realizados por Menezes et al. (2007), os quais apontam que nos leilões reversos, a organização compradora interage com diversas organizações fornecedoras e para tal, informam o preço máximo que admitem pagar por um determinado bem ou serviço e, em seguida, recebem lances decrescentes de fornecedores interessados.

Assim, com base na percepção apontada pelos autores supracitados, a corrrelação acima evidenciada ratifica a análise comentada em linhas passadas, sugerindo mais uma vez a incidência do oportunismo por parte dos agentes econômicos envolvidos nos pregões analisados. Nesse sentido, o uso do pregão parece não ter sido suficiente para coibir as ações 
de oportunismo, as quais, se não podem ser caracterizadas diretamente como fraudes premeditadas, beiram perigosamente esses princípios (OURA et al., 2012).

Outro ponto a ser explorado é a correlação positiva entre as variáveis $\underline{n^{0} \text { de licitantes }}$

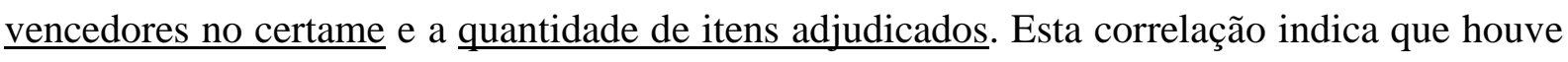
uma concorrência mais acirrada pelo objeto leiloado, o que proporcionou ofertas mais competitivas pelos fornecedores participantes do processo. A afirmativa em questão corrobora-se com estudo realizado por Silva (2007), o qual aponta que em se admitindo uma maior competição entre os participantes do mercado (traduzindo-se em um maior número de licitantes), haveria uma concorrência mais acirrada pelo objeto leiloado, impossibilitando, assim, posições monopolísticas, as quais tendem a promover a concentração do mercado e a elevar as taxas praticadas nos leilões.

Nesse aspecto, um procedimento eficiente é aquele que consegue utilizar os recursos disponíveis em quantidade, qualidade e custo satisfatórios à efetiva concretização de um objetivo. Contudo, a ideia de eficiência administrativa não deve estar atrelada somente ao aproveitamento dos meios e recursos colocados à disposição dos agentes públicos, mas também à adequação lógica desses meios, razoavelmente utilizados para a consecução dos resultados efetivamente obtidos, e à relação apropriada desses resultados com as necessidades públicas existentes.

O teste estatístico de Mann-Whitney-Wilcoxon, é um teste projetado para efetuar uma comparação estatística das médias. Desta forma, a tabela 2, apresenta a estatística das médias das variáveis objetos da análise em comento, com a opção de duas hipóteses: uma unilateral e outra bilateral. A hipótese unilateral testa se o valor médio de 2011 é menor ou igual ao valor médio de 2012, enquanto que a hipótese bilateral testa apenas se há uma diferença significativa nas médidas dos dois anos comparados.

O resultado do teste estatístico indica que para todas as variáveis testadas não existe diferença estatisticamente significante entre as médias de 2011 e as médias de 2012. Esta afirmativa pode ser constatada pelo p-valor dos testes (Unilateral: Asymp. Sig. (2-tailed) / Bilateral Exact Sig. [2*(1-tailed Sig.)]), que é maior que 0,5 (quando o nível de significância do teste é 5\%, (o mais utilizado) para todos os casos (para serem estatisticamente significantes os valores teriam que ser menores que 0,05). Logo, é possível inferir que não há diferença significativa entre as médias apresentadas, considerando-se a mudança no planejamento de compras após 2012. 
Tabela 2 - Teste Estatístico Mann-Whitney-Wilcoxon

\begin{tabular}{|c|c|c|c|c|c|c|c|c|c|}
\hline & $\begin{array}{c}\text { QTD. DE } \\
\text { ITENS } \\
\text { LICITADOS }\end{array}$ & $\begin{array}{l}\text { Q TD. DE } \\
\text { ITENS } \\
\text { ADJUDI } \\
\text { CADOS }\end{array}$ & $\begin{array}{c}\text { FASE } \\
\text { INTERNA } \\
\quad \text { dias } \\
\text { corridos) }\end{array}$ & $\begin{array}{c}\text { FASE EXTERNA } \\
\text { (dias corridos) }\end{array}$ & $\begin{array}{c}\text { TEMPO } \\
\text { TO TAL DA } \\
\text { LIC ITAÇÃO } \\
\text { (dias } \\
\text { corridos) }\end{array}$ & $\begin{array}{c}\mathbf{N}^{\circ} \text { DE } \\
\text { LIC ITANTES } \\
\text { NO } \\
\text { CERTAME }\end{array}$ & $\begin{array}{c}\mathrm{N}^{\circ} \text { DE } \\
\text { LICITANTES } \\
\text { VENCEDO RES } \\
\text { NO CERTAME }\end{array}$ & $\begin{array}{c}\text { VLR. } \\
\text { ESTIMADO } \\
\text { DO } \\
\text { PROCESSO }\end{array}$ & $\begin{array}{l}\text { VLR. TOTAL } \\
\text { HOMOLOGA } \\
\text { DO }\end{array}$ \\
\hline Mann-Whitney U & 107,500 & 109,000 & 100,000 & 82,000 & 93,000 & 111,000 & 111,500 & 111,000 & 107,000 \\
\hline Wilcoxon W & 227,500 & 229,000 & 220,000 & 202,000 & 213,000 & 231,000 & 231,500 & 231,000 & 227,000 \\
\hline Z &,- 208 &,- 145 &,- 518 & $-1,265$ &,- 809 &,- 062 &,- 042 &,- 062 &,- 228 \\
\hline Asymp. Sig. (2-tailed) &, 836 &, 884 & ,604 & ,206 & ,419 & ,950 & ,967 &, 950 & 820 \\
\hline $\begin{array}{c}\text { Exact Sig. [2*(1-tailed } \\
\text { Sig. })]\end{array}$ &, $838^{\mathrm{a}}$ &, $902^{\mathrm{a}}$ &, $624^{\mathrm{a}}$ &, $217^{\mathrm{a}}$ &, $436^{\mathrm{a}}$ &, $967^{\mathrm{a}}$ &, $967^{\mathrm{a}}$ & $967^{\mathrm{a}}$ &, $838^{\mathrm{a}}$ \\
\hline
\end{tabular}

A tabela (3) de Ranks das médias dos grupos dos pregões de 2011 e 2012, apresenta as médias das variáveis analisadas nos 15 grupos de produtos e serviços nos exercícios de 2011 e 2012.

Tabela 3 - Ranks das Média dos Grupos dos Pregões de 2011 - 2012

\begin{tabular}{|c|c|c|c|c|}
\hline VARIÁVEIS & ANO & $\begin{array}{c}\mathbf{N}^{\circ} \text { DE } \\
\text { GRUPOS }\end{array}$ & MÉDIA & SOMA DAS FILEIRAS \\
\hline \multirow[t]{3}{*}{ QTD. DE ITENS LICITADOS } & 2011 & 15 & 15,83 & 237,50 \\
\hline & 2012 & 15 & 15,17 & 227,50 \\
\hline & Total & 30 & & \\
\hline \multirow[t]{3}{*}{ QTD. DE ITENS ADJUDICADOS } & 2011 & 15 & 15,73 & 236,00 \\
\hline & 2012 & 15 & 15,27 & 229,00 \\
\hline & Total & 30 & & \\
\hline \multirow[t]{3}{*}{ FASE INTERNA (dias corridos) } & 2011 & 15 & 14,67 & 220,00 \\
\hline & 2012 & 15 & 16,33 & 245,00 \\
\hline & Total & 30 & & \\
\hline \multirow[t]{3}{*}{ FASE EXTERNA (dias corridos) } & 2011 & 15 & 13,47 & 202,00 \\
\hline & 2012 & 15 & 17,53 & 263,00 \\
\hline & Total & 30 & & \\
\hline \multirow{3}{*}{$\begin{array}{l}\text { TEMPO TOTAL DA LICITAÇÃO (dias } \\
\text { corridos) }\end{array}$} & 2011 & 15 & 14,20 & 213,00 \\
\hline & 2012 & 15 & 16,80 & 252,00 \\
\hline & Total & 30 & & \\
\hline \multirow[t]{3}{*}{$\mathrm{N}^{\circ}$ DE LICITANTES NO CERTAME } & 2011 & 15 & 15,60 & 234,00 \\
\hline & 2012 & 15 & 15,40 & 231,00 \\
\hline & Total & 30 & & \\
\hline $\mathrm{N}^{\circ}$ DE LICITANTES VENCEDORES NO & 2011 & 15 & 15,57 & 233,50 \\
\hline \multirow[t]{2}{*}{ CERTAME } & 2012 & 15 & 15,43 & 231,50 \\
\hline & Total & 30 & & \\
\hline \multirow[t]{3}{*}{ VLR. ESTIMADO DO PROCESSO } & 2011 & 15 & 15,60 & 234,00 \\
\hline & 2012 & 15 & 15,40 & 231,00 \\
\hline & Total & 30 & & \\
\hline \multirow[t]{3}{*}{ VLR. TOTAL HOMOLOGADO } & 2011 & 15 & 15,87 & 238,00 \\
\hline & 2012 & 15 & 15,13 & 227,00 \\
\hline & Total & 30 & & \\
\hline
\end{tabular}

Fonte: $\mathrm{O}$ autor. 
Olhando para as diferenças de médias entre os anos, podemos perceber que apenas as variáveis fase interna, fase externa e o tempo total da licitação, apresentaram uma diferença absoluta maior que um e foram as variáveis que apresentaram menor p-valor na tabela dos testes. Desta forma, o estudo concluiu que as médias estão muito próximas umas das outras, e nesse sentido, é possível inferir que não houve evolução no planejamento de compras após o exercício de 2011.

Um ponto importante do estudo a ser destacado na correlação de postos de Spearman, é a relação entre o $\underline{n}^{\circ}$ de licitantes no certame e o valor total homologado. Pelo gráfico (1) de dispersão apresentado abaixo entre estas variáveis, sendo o valor total dado em milhares de reais, não há sugestão visual para a alteração na estrutura de correlação antes e após a implantação do novo planejamento de compras pelo DAF.

Gráfico 1 - Gráfico de dispersão

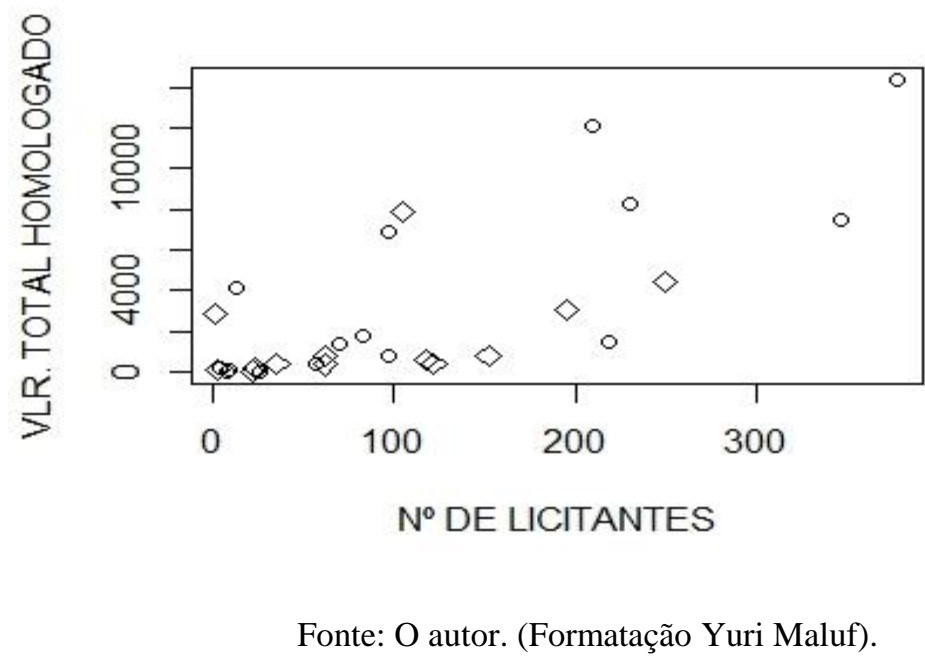

Para analisar se houve mudança na correlação captada pelo coeficiente de Spearman, adotou-se a seguinte estatística: THETA $=\boldsymbol{\rho}$ \{antes da implantação do novo planejamento de compras $\}$ - $\boldsymbol{\rho}$ \{depois da implantação do novo planejamento de compras . O coeficiente de correlação de Spearman antes da implantação do novo planejamento de compras $\boldsymbol{\rho}_{\mathbf{1}}$ (rho) foi estimado pelos dados do ano de 2011 e da mesma forma, a correlação depois do atual planejamento de compras $\boldsymbol{\rho}_{2}$ (rho), com dados de 2012. Na hipótese de que não haja mudança nessa estrutura de correlação, espera-se que a estatística THETA não seja estatisticamente diferente de zero. $\mathrm{O}$ valor amostral de THETA $=(0,82-0,66)=0,1537$. Para estimar o erro padrão de THETA e sua distribuição foi implementada a técnica do Bootstrap. 
Dessa forma, o histograma do gráfico 2, foi gerado a partir de 1000 amostras bootstraps. O intervalo de confiança de (90\%) foi estimado pelo método dos percentis. Estes valores são representados pelas linhas vermelhas tracejadas sendo $5 \%=-0,12$ e $95 \%=0,45$. Pelo gráfico observa-se que o intervalo compreende o valor zero, logo não há evidências para crer que antes e após a implantação do novo planejamento de compras, a correlação dos dados tenha mudado a $90 \%$ de confiança.

\section{Gráfico 2 - Histograma de Bootstrap}

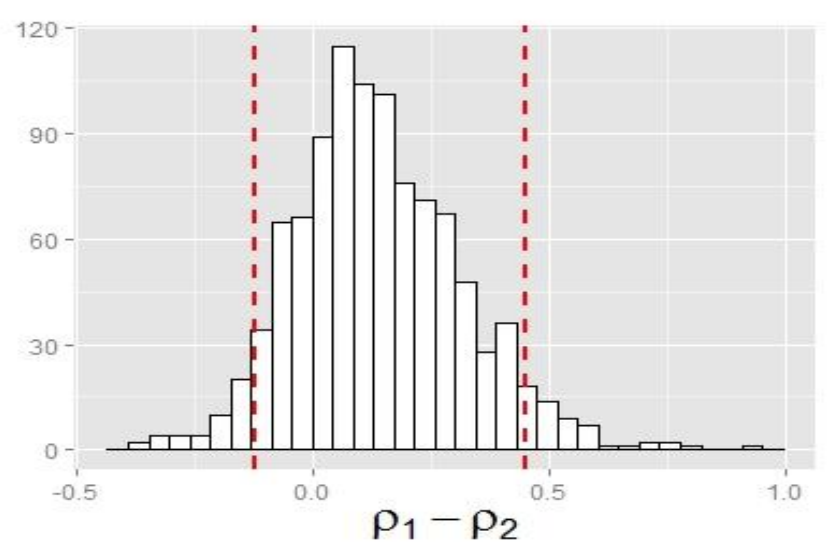

Fonte: O autor (Formatação do gráfico: Yuri Maluf)

Com o intuito de aclarar a conclusão inerente à análise supracitada, destacamos as características dos procedimentos de compras adotados pela UnB nos exercícios de 2011 e 2012, com a finalidade de propiciar uma análise comparativa dos procedimentos licitatórios ocorridos antes e após a implantação do planejamento de compras com o uso do calendário de compras.

Desta forma temos o seguinte:

\section{Características dos procedimentos de compras em 2011:}

a) Centralização dos pedidos de compras na DCO;

b) Existências de unidades descentralizadas com poderes para ordenar despesas tais como: BCE, CESPE, CDT, HUB e PRC;

c) Abertura de processo administrativo cadastrado no sistema UnBDoc;

d) Ausência de um planejamento das compras;

e) Pedidos de compras encaminhados a DCO de forma aleatória, com três orçamentos anexos, indicando em favor de qual empresa deveria ser emitida a nota de empenho, com base apenas no volume de recurso disponível;

f) Inexistência de padronização e racionalização de rotinas; 
g) Encaminhamento de pedidos de compra à DCO através de memorando, registrado no sistema UnBDoc;

h) Indicação do crédito orçamentário para formalização do pedido;

i) Encaminhamento do Termo de Referência com especificação detalhada do objeto e/ou descrição do serviço a ser contratado;

j) Envio de 3 orçamentos emitidos em favor da FUB;

k) Inexistência na equipe de apoio ao pregoeiro, de um servidor bacharel em Direito;

1) Inexistência de um catálogo de materiais que auxilie na especificação adequada do objeto a ser licitado.

\section{Característica dos procedimentos de compras após 2012:}

a) Criação do planejamento de compras "Compra Fácil”" (uma espécie de agenda de compras) contendo um calendário de compras, inicialmente, aplicado por semestre e nos anos subsequentes, durante todo o exercício vigente;

b) Centralização das Compras na Diretoria de Compras;

c) Unidades descentralizadas com poderes para ordenar despesas: CDT, HUB, PRC e $\mathrm{BCE}$;

d) Encaminhamento dos pedidos de compras dentro de prazos pré-estabelecidos;

e) Encaminhamento dos pedidos de compras via memorando, com registro no sistema UnBDoc;

f) Encaminhamento do Termo de Referência com especificação detalhada do objeto e/ou descrição do serviço a ser contratado;

g) Obrigatoriedade de lançamento dos pedidos de compras no sistema SIMAR;

h) Indicação do crédito orçamentário para formalização do pedido;

i) Pesquisa de preços com no mínimo três orçamentos;

j) Processamento das compras através de atas de registros de preços ou adesão à ata de registro de preço de outros órgãos;

k) Inexistência na equipe de apoio ao pregoeiro, de um servidor bacharel em Direito;

1) Inexistência de um catálogo de materiais que auxilie na especificação adequada do objeto a ser licitado.

Diante do panorama apresentado, depreende-se que antes de 2012, a forma usual de como as unidades encaminhavam as demandas para aquisição de bens e serviços comuns, resumia-se apenas em solicitar a três empresas do ramo, a apresentação de propostas em nome da FUB, contendo a especificação do objeto ou descrição do serviço a ser contratado; preços unitários e totais; a quantidade e indicação da marca dos produtos cotados e a validade da 
proposta. De posse desta documentação, a área demandante redigia um memorando no qual era solicitada a compra, anexando a nota de dotação dos recursos para cobrir a despesa, e, posteriormente, encaminhava a documentação a DCO, indicando em favor de qual empresa deveria ser emitida a nota de empenho. Dessa forma, a DCO acatava ou não a sugestão de da modalidade de compra sugerida.

Observa-se que como não havia um planejamento de compras e nenhuma padronização e racionalização de rotinas, os pedidos de compra, eram remetidos à DCO de forma aleatória, ou seja, a qualquer tempo, apenas com base em recursos disponíveis nas unidades, sem planejamento específico para as futuras aquisições. Com a ausência de um planejamento de compras, a padronização e a racionalização de rotinas, ocorria uma excessiva demora na conclusão dos procedimentos licitatórios, corroborando assim, com a afirmativa em estudos realizados por Rocha e Silva (2006). Ressalta-se ainda que os procedimentos licitatórios, sendo compostos por vários pedidos de compra contendo os mais diversos materiais, acarretavam em pregões pouco atrativos para as empresas, diminuindo a competitividade e consequentemente a oportunidade de ocorrer lances de valores mais baixos.

Convém salientar que além das modalidades de licitação por pregão eletrônico, concorrência, tomada de preços e convite, a modalidade de compra adotada para estas demandas, era em grande maioria, a dispensa de licitação. No entanto, esta modalidade de licitação é veementemente rechaçada pelos órgãos de controle da União como TCU, CGU e MPU, tendo em vista ser caracterizada como fracionamento da despesa. Nesse sentido, era preciso repensar o processo de compras, substituindo o sistema antiquado por um processo gerencial simples que criasse valor em cada compra e desta forma proporcionasse maior rigor no manejo dos recursos públicos.

Assim, em 2012, com o objetivo de proporcionar agilidade e celeridade aos procedimentos licitatórios, o DAF criou um planejamento de compras, adotando um calendário de compras, aplicando-o a cada semestre. Como objetivos complementares, ressaltou a redução de custos e o volume de procedimentos licitatórios.

Nesse contexto, com padrões de rotinas para procedimentos licitatórios, o planejamento de compras passou a contemplar o encaminhamento das demandas de compra das Unidades dentro de prazos pré-estabelecidos, sendo obrigatório o lançamento dessas demandas no sistema SIMAR. Com isto, a previsão é de que as compras fossem processadas através de atas de registro de preços próprias ou por adesão à ata de registro de preço de outros órgãos da União. 
Contudo, no decorrer dos anos, várias unidades demandantes por aquisição de bens e serviços comuns, oriundas dos quatro Campi da UnB, vem apresentando dificuldades para executar os seus orçamentos em função da criação do atual planejamento de compras com o uso do calendário de compras. Soma-se a isto, a centralização das compras na Diretoria de Compras localizada no campus Darcy Ribeiro, a qual segundo Campos (2013) vem provocando uma excessiva morosidade nos procedimentos licitatórios, uma vez que os prazos dos procedimentos licitatórios extrapolam.

Salienta-se ainda, a ausência de divulgação do orçamento disponível em tempo hábil para as unidades, prejudicando assim, o planejamento das solicitações, já que se corre o risco de licitar algo e não haver recursos suficientes para a compra; ou o contrário, haver recursos, mas não haver licitação finalizada para a emissão de empenhos.

No tocante aos prazos para elaboração da relação de todas as demandas da Unidade para aquisição de bens e serviços, os mesmos são considerados insuficientes. Essa ocorrência, consequentemente, aumenta as chances de se incumbir em erros na elaboração dos pedidos e se algum material não for incluído, deverá aguardar o próximo período do calendário. Nesse quesito, ressalta-se que alguns itens que necessitam ser comprados prontamente, por necessidade da unidade, tem que aguardar o prazo do calendário correspondente para serem licitados e por conseguinte, docentes que ingressam na instituição no decorrer do ano, não conseguem planejar as compras e encaminhar seus pedidos dentro dos prazos estipulados pelo calendário.

Considera-se ainda que durante a análise dos pedidos de compras pela Coordenadoria de Instrução Processual (CAIP), um grande número de pedidos é devolvido aos Campi para que sejam feitas adaptações e correções da documentação. Posteriormente, esses pedidos em algum momento, retornam para a CAIP, no entanto, além de causar retrabalho, atrapalha na montagem dos processos licitatórios, que tendem a reunir materiais do mesmo grupo pela similaridade da natureza. Ressalta-se que este tipo de ocorrência é observada tanto nos processos anteriores quanto nos processos subsequentes à implantação do planejamento de compras. 


\section{CONCLUSÃO}

\subsection{Considerações finais}

Essa dissertação de mestrado teve por objetivo avaliar o planejamento de compras estabelecido pela UnB em 2012, no intuito de buscar evidências que pudessem aclarar o questionamento inerente a sua eficiência e eficácia para os processos licitatórios da UnB.

Pela análise do coeficiente de correlação de postos de Spearman's, o estudo possibilitou concluir que ocorreu uma elevação nos custos de transação decorrente de ações oportunistas por parte dos agentes envolvidos nos pregões analisados. Concluiu-se também que o tempo gasto na preparação do procedimento na fase interna, não foi o resultado esperado, considerando-se as características peculiares do Pregão, no que se refere à celeridade na elaboração dos procedimentos licitatórios para a aquisição de bens e serviços comuns.

Em relação à tabela de ranks das médias das categorias dos pregões objetos do estudo, o resultado demonstra que as médias estão muito próximas uma das outras e nesse sentido, é possível inferir que não houve evolução no planejamento de compras após o exercício de 2012 .

No tocante ao teste estatístico de Mann-Whitney-Wilcoxon, concluiu-se que não houve diferença significativa entre as médias apresentadas pela correlação entre as variáveis $\mathrm{n}^{\circ}$ de licitantes no certame x valor total homologado em 2011 e 2012.

O resultado da análise estatística do histograma de bootstrap, referente à correlação de postos de Spearman entre as variáveis $\mathrm{n}^{\mathrm{o}}$ de licitantes no certame e o valor total homologado, permitiu concluir que não há evidências para crer que antes e após a implantação do atual planejamento de compras, a correlação dos dados tenha mudado a 90\% de confiança.

Assim, a pesquisa concluiu que a nova sistemática de compras mostrou-se fragilizada e ineficiente, contrariando suas expectativas iniciais, que eram de tornar mais célere e eficiente o procedimento licitatório no âmbito da $\mathrm{UnB}$, com a consequente redução de preços e a diminuição do volume de compras.

Como limitações da pesquisa, destaca-se que o estudo limitou-se a análise dos pregões executados pela Diretoria de Compras do campus Darcy Ribeiro, homologados nos exercícios de 2011 e 2012, descartando-se da pesquisa, os pregões realizados pelas unidades descentralizadas BCE, CDT, HUB e PRC. 
Como sugestões, é imprescindível que o setor de compras reveja os procedimentos inerentes ao atual planejamento de compras, no sentido de implementar rotinas que impliquem em maior celeridade, eficiência e eficácia para os processos de licitação, o que certamente, proporcionará maior rigor no manejo dos recursos públicos destinados à Instituição.

Recomenda-se que sejam estabelecidos critérios mais eficientes durante a etapa de realização da fase interna, com a finalidade de minimizar a assimetria de informações e, consequentemente, coibir as ações oportunistas dos agentes econômicos envolvidos nos processos licitatórios, as quais poderiam resultar na elevação dos custos de transação. No entanto, os responsáveis por este procedimento, devem tomar o devido cuidado com o "excesso" de informações, pois se corre o risco de minimizar muito a concorrência, o que poderia também, ocasionar a elevação dos preços. Sugere-se também, que seja realizado o desenvolvimento de um sistema de gerenciamento dos preços orçados e do monitoramento do ambiente externo, de uso concomitante ao uso do sistema por pregão, com a finalidade de identificar potenciais fornecedores do mercado no momento de realização do processo.

Por fim, recomenda-se que seja realizada uma análise qualitativa do uso do calendário de compras, no sentido de se conhecer as opiniões e estratégias dos diversos demandantes por aquisição de bens e serviços da Instituição, com a finalidade de que seja possibilitada a realização de trabalhos futuros, visando à incorporação de novas variáveis que possam proporcionar melhorias a serem aplicadas no calendário de compras supracitado. 


\section{REFERÊNCIAS}

ALCÂNTARA, Christian Mendez. Constituição, Economia e Desenvolvimento: Revista da Academia Brasileira de Direito Constitucional. Curitiba, 2009, n. 1, Ago-Fez. P. 24-49. Disponível em: <http://www.abdconst.com.br/revista/ARTIGO\%202.pdf> Acesso em 18.08.2015.

AMARAL, Antonio Carlos Cintra do. Comentando as Licitações Públicas. v. 3. Rio de Janeiro: Temas e Ideias, 2002.

ANDRADE, Fernanda; SANTANA, Jair Eduardo. Legislação: licitações, pregão presencial e eletrônico, leis complementares. Curitiba: Negócios Públicos, 2008.

ARAÚJO, Paulo Maria Costa de.; JESUS, Renata Gomes de. Processo Licitatório Tipo Menor Preço e Eficiência em Compras Públicas: um Estudo de Caso. Rio de janeiro: XXXVII Encontro da ANPAD. Rio de Janeiro, 2013. Disponível em:< http://www.fucape.br/_public/producao_cientifica/2/APB411$\% 20$ Paula\%20Mara\%20Costa\%20de\%20Araujo.pdf>. Acesso em 22 jun 2015.

BACELLAR FILHO, Romeu Felipe. Direito Administrativo. 2. ed. rev. e atual. São Paulo: Saraiva, 2005.

BÄCHTOLD, Ciro. Noções de Administração Pública. Cuiabá: EdUFMT; Curitiba: UFPR, 2008.

BAILY, Peter; FARMER, David et al. Compras: princípios e administração. São Paulo: Atlas, 2010.

BATISTA, Marco Antonio Cavalcanti; MALDONADO, José Manuel Santos de Varge. O papel do comprador no processo de compras em instituições públicas de ciência e tecnologia em saúde (C\&T/S). Revista de Administração Pública, Rio de Janeiro, v. 42, n. 4, ago. 2008. Disponível em: <http://www.scielo.br/scielo.php?script=sci_arttext\&pid=S0034$76122008000400003 \& \operatorname{lng}=$ pt\&nrm=iso $>$. Acesso em: 17 jan. 2015.

BENJAMIN Zymler. Avanços no Sistema de Registro de Preços com o Decreto 7.892/13. Revista O Pregoeiro. V. 9, n 100 , mar. 2013.

BIO, Sérgio Rodrigues. Sistemas de Informação: um enfoque gerencial. São Paulo: Atlas, 1996. P. 20-23.

BRASIL. Decreto-Lei n. 200, de 25 de fevereiro de 1967. Dispõe sobre a organização da Administração Federal, estabelece diretrizes para a Reforma Administrativa e dá outras 
providências. Disponível em: <http://www.planalto.gov.br/ccivil_03/decretolei/Del0200.htm >. Acesso em: 3 abr. 2014.

BRASIL. Lei. 8.666, de 21 de junho de 1993. Institui normas para licitações e contratos da Administração Pública e dá outras providências. Disponível em:

<http://www.planalto.gov.br>. Acesso em 04 abr. 2014.

BRASIL. Presidência da República. Câmara da Reforma do Estado. Plano Diretor da

Reforma do Aparelho de Estado. Brasília, 1995. Disponível em: <

http://www.bresserpereira.org.br/documents/mare/planodiretor/planodiretor.pdf $>$ Acesso em

04 abr. 2014.

BRASIL. Lei. 9.648 de 27 de maio de 1998. Altera dispositivos das Leis no 3.890-A, de 25 de abril de 1961, no 8.666, de 21 de junho de 1993, no 8.987, de 13 de fevereiro de 1995, no 9.074, de 7 de julho de 1995, no 9.427, de 26 de dezembro de 1996, e autoriza o Poder Executivo a promover a reestruturação da Centrais Elétricas Brasileiras ELETROBRÁS e de suas subsidiárias e dá outras providências. Disponível em http:<//www.planalto.gov.br/ccivil_03/leis/19648cons.htm>. Acesso em 17 jan. 2015.

BRASIL. Constituição 1988. Constituição da República Federativa do Brasil: promulgada em 5 de outubro de 1988. Disponível em:

http://www.planalto.gov.br/ccivil_03/constituicao/constituicao.htm. Acesso em 03 abr. 2014.

BRASIL. Emenda constitucional n. 19, de 4 de junho de 1998. Modifica o regime e dispõe sobre princípios e normas da Administração Pública, servidores e agentes políticos, controle de despesas e finanças públicas e custeio de atividades a cargo do Distrito Federal, e dá outras providências. Disponível em:

<http://www.planalto.gov.br/Civil_03/Constituicao/Emendas/Em c/emc19.htm>. Acesso em: 10 out 2014.

BRASIL. Lei n. 9.784, de 29 de janeiro de 1999. Regula o processo administrativo no âmbito da Administração Pública Federal. Disponível em:

<http://www.planalto.gov.br/Ccivil_03/LEIS/L9784.htm>. Acesso em: 10 out 2014.

BRASIL. Lei 10.520, de 17 de julho de 2002. Institui, no âmbito da União, Estados, Distrito Federal e Municípios, nos termos do art. 37, inciso XXI, da Constituição Federal, modalidade de licitação denominada pregão, para aquisição de bens e serviços comuns, e dá outras providências. Disponível em: http://www.planalto.gov.br. Acesso em 04 abr. 2014.

BRASIL. Decreto $n^{\circ} 5.450$, de 31 de maio de 2005. Regulamenta o pregão, na forma eletrônica, para aquisição de bens e serviços comuns, e dá outras providências. Disponível em: http://www.planalto.gov.br>. Acesso em 04. Abr. 2014.

BUENO, Júlio; OLIVEIRA, Ricardo de. ENAP - Escola Nacional de Administração Pública. Rio de Janeiro, 2002. Disponível em: 
$<$ http://www.enap.gov.br/index.php?option=com_content\&task=view\&id=266>. Acesso em 14 mar 2015.

BRAZ, Petrônio. Processo de licitação: contrato administrativo e sanções penais. São Paulo: Livraria de Direito, 1995.

BREITENBACH, Raque; BRANDÃO, Janaína Balk; SOUZA, Renato Santos de. Teorias Organizacionais e a Nova Economia Institucional: uma discussão acerca dos elementos constitutivos das organizações. $47^{\circ}$ Congresso da SOBER. Porto Alegre. 2009. Disponível em:<http://www.sober.org.br/palestra/13/477.pdf>. Acesso em 22 jun 2015.

CADERNOS MARE DA REFORMA DO ESTADO. Programa de Reestruturação e Qualidade dos Ministérios. Disponível em:

http://www.planejamento.gov.br/secretarias/upload/Arquivos/publicacao/seges/PUB_Seges_ Mare_caderno12.PDF. Acesso em 28 jan. 2015.

CAMPOS, Suamir Jorge de Azevedo. Compras Públicas: estudo de caso da Universidade de Brasília, 60 p. Mestrado Profissional em Gestão Econômica de Finanças Públicas. Universidade de Brasília. Brasília, 2013. Disponível em:

<http://repositorio.unb.br/handle/10482/16613>. Acesso em 24 jul 2015.

CARTER, Craig R.; STEVENS, Cyntthia Kay. Eletronic reverse auction configuration and its impact on buyer price and supplier perceptions of opportunism: A laboratory

experiment. Journal of Operations Management, v. 25, n. 5, p. 1035-1054, 2007. Disponível em: <http://www.sciencedirect.com/science/article/pii/S0272696306001161> . Acesso em 18 jun 2015.

CATELLI, Armand; PARISI, Cláudio; SANTOS, Edilene Santana; ALMEIDA, Lauro Brito de. Um sistema para a gestão econômica de organizações governamentais

empreendedoras. Revista do Serviço Público, Brasília, ano 52, n.3, jul-set. 2001. Disponível em: <http://www.enap.gov.br/index.php?option=com_docman\&task=doc_view\&gid=2662>. Acesso em: jan. 2015.

COSTA, A. L. Sistemas de compras privadas e públicas no Brasil. Revista de Administração, São Paulo v. 35, n.4, p. 119 - 128. Out/Dez 2000.

COUTO, A. R. de O.; RAMOS, H. B. P.; GRAZZIOTIN, P. A contratação na Administração Pública. Belo Horizonte: Fórum, 2009.

CRETELLA JUNIOR, José. Licitações e contratos do estado. Rio de Janeiro: Forense, 1999.

DINIZ, E. A., STOFEFEL, J.A.; GOEBEL, M.A. Licitações e compras públicas de alimentos numa perspectiva da Nova Economia Institucional: o caso Toledo (PR). Revista Informe Gepec, v. 8, n. 2, jul./dez. 2004. Disponível em: < http://erevista.unioeste.br/index.php/gepec/article/view/312 > . Acesso em 27 jun 2015. 
DI PIETRO, Maria Sylvia Zanella. Direito administrativo. 10. ed. São Paulo: Atlas, 1999.

DIPIETRO, Maria Sylvia Zanella. Direito administrativo. São Paulo: Atlas, 2002.

Direito Administrativo. 15ª ed. São Paulo: Atlas, 2003.

DORELLA, Micheli Ribeiro Massi; SOARES, Roberta Moraes Raso Leite. Sistema de registro de preços: 0 "carona" à luz das inovações decorrentes do Decreto Federal $\mathbf{n}^{\circ}$ 7.892/13. Disponível em: < http://revista.tce.mg.gov.br/Content/Upload/Materia/1965.pdf> Acesso em: 14. Mai. 2014.

DURÃES, M.S.D. Teoria dos leilões: abordagem comparativa com ênfase nos leilões de títulos do Tesouro no Brasil e em outros países. Disponível em:

http://www3.tesouro.fazenda.gov.br/Premio_TN/IIpremio/divida/2afdpIVPTN/DURAES_Ma risa_Socorro.pdf> Acesso em 18 jun 2015.

FARIA, E. Rodrigues; FERREIRA, M. A. Marques; SANTOS, L. M. dos; ABRANTES, L. Antônio. Aspectos transacionais e comportamentais dos agentes no Pregão Eletrônico: um enfoque na administração pública. Revista de Economia e Administração, v.9, n.2, 151169p, abr./jun. 2010. Disponível em: <

http://www.spell.org.br/documentos/ver/5014/aspectos-transacionais-e-comportamentais-dosagentes-no-pregao-eletronico--um-enfoque-na-administracao-publica>. Acesso em: 27 jun 2015.

FARIA; Evandro Rodrigues de; FERREIRA, Marco Aurélio Marques; SANTOS, Lucas Maia dos. Perfil das empresas participantes do processo de pregão eletrônico em uma instituição pública. Administração Pública e Gestão Social, v. 2, n. 2. Abr./jun. 2010. Disponível em:< http://www.apgs.ufv.br/index.php/apgs/article/view/30/146\#.VQjAhY7F9ig> Acesso em: 14 mai. 2014.

FARIA. Evandro Rodrigues de; FERREIRA, Marco Aurélio Marques; SANTOS, Lucas Maia dos; SILVEIRA, Suely de Fátima Ramos. Fatores determinantes na variação dos preços dos produtos contratados por pregão eletrônico. Revista de Administração Pública. vol. 44, $\mathrm{n}^{\circ}$ 6. Rio de Janeiro. Nov/Dez 2010. Disponível em:< http://www.scielo.br/scielo.php?pid=S0034-76122010000600007\&script=sci_arttext $>$. Acesso em 12 jun. 2015.

FARIA, Evandro Rodrigues de et al. Pregão Eletrônico Versus Pregão Presencial: Estudo Comparativo de Redução de Preços e Tempo. Revista de Contabilidade do Mestrado em Ciências Contábeis da UERJ, Rio de janeiro, v. 16, n. 1. Jan./abril, 2011. Disponível em: $<$ http://www.spell.org.br/documentos/ver/57/pregao-eletronico-versus-pregao-presencial-estudo-comparativo-de-reducao-de-precos-e-tempo>. Acesso em: 14 mai 2014. 
FARIA, Evandro Rodrigues de.; FERREIRA, Marco Aurélio Marques.; GONÇALVES, Márcio Augusto. Avaliação dos Riscos do Pregão Eletrônico: uma Abordagem pela Teoria da Nova Economia Institucional. Revista de Ciência da Administração, v. 15, n. 37, p. 211-227, dez. 2013. Disponível em:

<https://periodicos.ufsc.br/index.php/adm/article/view/2175-8077.2013v15n37p211>. Acesso em 27 jun 2015.

FELICIDADE, Rafaela Suzana de Nazaré; PENA, Cláudia Brito. Licitação Por Pregão Eletrônico: economicidade, celeridade e transparência na Secretaria de Estado da Fazenda do Pará - SEFA. VII SEGeT - 2010. Disponível em:

$<$ http://www.aedb.br/seget/artigos10/295_TCC\%20Simposio\%20de\%20Gestao\%20e\%20Exc elencia\%20em\%20Tecnologia.pdf >. Acesso em 07 abr. 2014.

FERNANDES THIAGO, Albuquerque. Sistema de Registro de Preços: um procedimento especial para aquisição de bens e serviços. Sítio: Webartigos. Brasília dez 2008. Disponível em: <http://www.webartigos.com/articles/12120/1/Sistema-de-Registro-de-Preço---

SRP/pagina1.html>. Acesso em 14 mai. 2014.

FROES, César; MELO NETO, Francisco Paulo. Administração Pública. Rio de janeiro: UCB/EB, 2006.

FILHO, José dos Santos Carvalho. Manual de Direito Administrativo. 21. ed., Rio de Janeiro: Lumen Juris, 2009.

FURTADO, Lucas Rocha. Curso de Licitações e Contratos Administrativos - Teoria, Prática e Jurisprudência. São Paulo: Atlas, 2001.

FURTADO, Madeline Rocha. Sistema de Registro de Preços: considerações práticas. Brasília: 07 nov. 2007. Disponível em: < http://www.clubjus.com.br/?artigos\&ver=2.11500>. Acesso em 13 mai. 2014.

GABARDO, Emerson. Eficiência e Legitimidade do Estado: uma análise das estruturas simbólicas do direito político. Barueri, SP: Manole, 2003.

GIL, A. C. Como elaborar projeto de pesquisa. $4^{\text {a }}$ ed. São Paulo: Atlas, 2002.

GOMES, Eduardo Granha Magalhães. Gestão por Resultados e eficiência na Administração Pública: uma análise à luz da experiência de Minas Gerais. Disponível em:

<http://bibliotecadigital.fgv.br/dspace/bitstream/handle/10438/4652/72050100745.pdf?sequen ce $=1 \&$ isAllowed=y $>$. Acesso em: 12 abr. 2015.

GOMES, Maria Lucineide Serpa; Oliveira, Francisco Correia de. Modelos Organizacionais de Administração Pública: um estudo dos aspectos da realidade cearense na estrutura de referência das reformas do Estado. Revista de Ciências da Administração. V. 12, n. 28, 
p. 105-126, set/dez 2010. Disponível

em:<https://periodicos.ufsc.br/index.php/adm/article/view/2175-8077.2010v12n28p105>. Acesso em 28 jan. 2015.

GONÇALVES, Rodrigo Allan Coutinho. O "carona" no sistema de registro de preços conforme Decreto no 7.892/2013. Jus Navigandi, Teresina, ano 18, n. 3519, 18 fev. 2013. Disponível em: <http://jus.com.br/revista/texto/23747>. Acesso em 15 abr. 2014.

JACOBY FERNANDES, Jorge Ulisses. Carona em Sistema de Registro de Preços: uma opção inteligente para redução de custos e controle, 2006. Disponível em:

<http://www.jacoby.pro.br/utilpu/CAC58T8N.doc>. Acesso em: 14 mai. 2014

JACOBY FERNANDES, Jorge Ulisses. Carona em Sistema de Registro de Preços: uma opção inteligente para redução de custos e controle. Revista O Pregoeiro, v. 3, out. 2007 Disponível em: <http://www.jacoby.pro.br/Carona.pdf>. Acesso em: 14 mai. 2014.

JACOBY FERNANDES, Jorge Ulisses. Avanços no Sistema de Registro de Preços com o Decreto 7.892/13. Revista O Pregoeiro. V. 9, nº 100, mar. 2013.

JUSTEN FILHO, Marçal. Comentários à Lei de licitações e contratos administrativos. 10. Ed. São Paulo: Dialética, 2004. . $12^{\mathrm{a}}$ ed. São Paulo: Dialética. 2008. 14ª ed. São Paulo: Dialética. 2010.

KLERING, Luis Roque; PORSSE, Melody de Campos Soares; GUADAGNIN, Luis Alberto. Novos Caminhos da Administração Pública Brasileira. Análise, Porto Alegre, v. 21, n. 1, p. 4-17, jan/jun. 2010. Disponível em: < http://revistaseletronicas.pucrs.br/face/ojs/index.php/face/article/view/8231/5903>. Acesso em 30 jan 3015.

LAUREANO, F. H. G. C. A indústria de gás natural e as relações contratuais: uma análise do caso brasileiro. Dissertação de Mestrado em Engenharia da UFRJ. Rio de janeiro, 2005. Disponível em: <http://www.ppe.ufrj.br/ppe/production/tesis/flaureano.pdf>. Acesso em: 27 jun 2015.

LINHARES, Sonalba. Administração pública brasileira, [200-?]. Disponível em <http://www.enap.gov.br/downloads/ec43ea4fSlide2.ppt>. Acesso em 15 jan. 2015.

MARQUES, Marcelo. Administração Pública: uma abordagem prática. Rio de Janeiro, 2008. 
MELLO, Celso Antônio Bandeira de. Curso de Direito Administrativo. 14. ed. São Paulo: Malheiros, 2002. . 19. ed. São Paulo: Malheiros, 2005.

MEIRELLES, Hely Lopes. Direito Administrativo Brasileiro. São Paulo: Malheiros, 1989. . São Paulo: Malheiros, 1996.

MENEZES, Ronald do Amaral; SILVA, Renaud Barbosa da; LINHARES, A. Leilões eletrônicos reversos multiatributo: uma abordagem de decisão multicritério aplicada às compras públicas brasileiras. Revista de Administração Contemporânea, vol. 11, n. 3, Curitiba, jul./set. 2007. Disponível em: <

http://www.scielo.br/scielo.php?script=sci_arttext\&pid=S1415-65552007000300002 >. Acesso em 14 mai 2014.

MENDONÇA, José Hildenberg Fagundes. A Relevância dos serviços meios para a eficiência da prestação jurisdicional. Ceará 2008. Disponível em: < https://www.google.com.br/webhp?sourceid=chrome-instant\&ion=1\&espv=2\&ie=UTF$8 \# \mathrm{q}=\mathrm{MENDON} \% \mathrm{C} 3 \% 87 \mathrm{~A} \% 2 \mathrm{C}+\mathrm{J}$ os\%C3\%A9+Hildenberg+Fagundes.+A+Relev\%C3\% A2n cia+dos+servi\%C3\%A7os+meios+para+a+efici\%C3\%AAncia+da+presta\%C3\%A7\%C3\%A3 o+jurisdicional> Acesso em 10 jun 2015.

MORAES. Alexandre de. Reforma administrativa - Emenda constitucional n. 19/98. 2.ed. São Paulo: Atlas, 1999.

Direito Constitucional Administrativo. São Paulo: Atlas, 2002.

MOREIRA NETO, Diogo de Figueiredo. Apontamentos sobre a reforma administrativa. Rio de Janeiro: Renovar, 1999.

NASCIMENTO, Rodrigo Limp. Análise dos fatores de influência nas propostas ofertadas nos leilões de transmissão de energia elétrica. Brasília, 2012. Disponível em: http://repositorio.unb.br/bitstream/10482/11348/1/2012_RodrigoLimpNascimento.pdf. Acesso em 19 jun 2015.

NIEBUHR, Joel de Menezes. Pregão Presencial e Eletrônico. Curitiba. Zênite. 2004.

OLIVEIRA, Gustavo Justino. Contrato de Gestão. São Paulo: RT, 2008.

ORMOND, Derry; LOFFLER, Elke. A nova gerência pública. RSP - Revista do Serviço Público. Ano 50, n. 2, abr./jun. p. 66-96, 1999. Disponível em: <http://seer.enap.gov.br/index.php/RSP/article/view/347/353>. Acesso em 19 fev. 2015 
OURA, Maurício Massao; KONO, Carlos Mamori; RODRIGUES, Leonel Cewzar; RICCIO, Edson Luiz. O Pregão Eletrônico como Instrumento de Controle de Oportunismo no Processo Licitatório Público. Revista de Gestão e Projetos - GeP, São Paulo, v. 3, n. 2, p 260-281, mai./ago.2012. Disponível em:<

http://www.revistagep.org/ojs/index.php/gep/article/view/118. Acesso em 19 jun 2015.

OSBORNE, David; GAEBLER, Ted. Reinventando o Governo: como o espírito empreendedor está transformando o Setor Público. Brasília: MH Comunicação, 1998.

PEÑA, Carlos Rosano. Um Modelo de Avaliaçăo da Eficiência da Administraçăo Pública através do Método Análise Envoltória de Dados (DEA). Disponível em:< http://www.scielo.br/pdf/rac/v12n1/a05v12n1>. Acesso em 24 abr 2015.

PEREIRA, Luiz Carlos Bresser. Da Administração Pública Burocrática à Gerencial. Disponível em: <

http://www.bresserpereira.org.br/papers/1996/95.admpublicaburocraticaagerencial.pdf>. Acesso em 28 jan 2015.

PEREIRA, Luiz Carlos Bresser. A Reforma do Estado dos anos 90: Lógica e Mecanismos de Controle. Ministério da Administração Federal e Reforma do Estado. Brasília, 1997. Disponível em:

<http://www.bresserpereira.org.br/documents/MARE/CadernosMare/CADERNO01>. Acesso em: 28 jan. 2015.

PEREIRA, Luiz Carlos Bresser. Gestão do setor público: estratégia e estrutura para um novo Estado. In: PEREIRA, Luís Carlos Bresser; SPINK, Peter Kevin (Orgs.). Reforma do Estado e Administração Pública Gerencial. Rio de janeiro: FGV, 2006.

REIS, Ruimar Barboza dos. Pregão presencial e eletrônico: cenário nacional. Curitiba: Negócios Públicos, 2008.

RIBEIRO, Andrea Cristina Pires de Azevedo Pinto; NUNES, Rogério da Silva; WEINZIERL, Greici e JACOBSEN, Alessandra de Linhares. Gestão por resultados na Administração Pública: A implantação do Núcleo Estadual do Ministério da Saúde em Alagoas.

Disponível em: < http://www.excelenciaemgestao.org/Portals/2/documents/cneg7/anais/T11_0419_1595.pdf>. Acesso em 16 mar 2015.

RIGOLIN, Ivan Barbosa; BOTTINO, Marco Tullio. Manual prático das licitações: Lei 8.666/1993. São Paulo: Saraiva, 2002.

ROCHA, Carmen Lúcia Antunes. Princípios Constitucionais dos servidores públicos. São Paulo: Saraiva, 1999. 
ROCHA, Renan Mendes; SILVA, Eudes de Queiroz e. Compras Governamentais: uma análise das causas da morosidade dos processos de compras no âmbito da FUB. 54 p. Monografia. Universidade de Brasília. Brasília 2006. Disponível em: < http://bdm.unb.br/handle/10483/1392> Acesso em 24 jul 2015.

SANTANA, Jair Eduardo. Pregão presencial e eletrônico: manual de implantação, operacionalização e controle. Belo Horizonte: Fórum, 2008.

SANTANA, Jair et al. Licitações, contratos administrativo, pregão eletrônico e presencial: leis complementares. Curitiba: Negócios Públicos, 2011.

SANTOS, Clézio Saldanha dos. Introdução á gestão pública. São Paulo: Saraiva, 2006.

SANTOS, S. R. S. A Nova Economia Institucional. In: SEMINÁRIO TEMÁTICO DO NÚCLEO DE ESTUDOS EM SOCIOLOGIA ECONÔMICA E DAS FINANÇAS, 1., 2007, São Paulo. Anais... São Paulo, 2007. Disponível em: <

file:///C:/Users/Convidado/Downloads/A+nova+economia+institucional\%20(1).pdf >. Acesso em 22 jun 2015.

SARTURI, Claudia Adriele. Os modelos de Administração Pública: patrimonialista, burocrática e gerencial. Conteúdo Jurídico. Brasília-DF: 21 maio 2013. Disponível em: <http://www. http://www.conteudojuridico.com.br/artigo,os-modelos-de-administracaopublica-patrimonialista-burocratica-e-gerencial,43523.html>. Acesso em 22 fev. 2015.

SCARPINELLA, Vera. Licitação na modalidade de pregão. 1. São Paulo: Malheiros, 2002.

SECCHI, Leonardo. Modelos organizacionais e reformas da Administração Pública. Revista Administração Pública, Rio de Janeiro, v. 43, n. 2, mar./abr.2009. Disponível em:< http://www.scielo.br/pdf/rap/v43n2/v43n2a04.pdf>. Acesso em 11 jan. 2015.

SILVA, Antônio Araújo da. A Economia das Compras Governamentais em decorrência do pregão eletrônico: uma abordagem econométrica, 49 p. Mestrado Profissional em Economia. Universidade Federal do Ceará. Fortaleza 2007. Disponível em: < http://www.repositorio.ufc.br/handle/riufc/5638>. Acesso em 18 jun 2015.

SILVA, Reinaldo Oliveira da. Teorias da Administração. São Paulo: Pioneira, 2001.

SILVA, Frank Van Rikard Santos da. Pará 2008. Gestão de Compras. Disponível em:〈https://www.administradores.com.br/producao-academica/gestao-de-compras/758>. Acesso em 24 abr 2015.

SILVA OLIVEIRA, Cleber Demetrio da. 01/2007. Gestão Pública. Disponível em: <http://www.rzoconsultoria.com.br/noticias.php?id=86>. Acesso em 14 mar 2015.

SOUZA, Karine Daniele Byhain de; CASTRO, Eduardo Bernardes de. Pregão: Vantagens e Desvantagens para a Administração Pública. VIII CNEG. Disponível em: 
<http://www.excelenciaemgestao.org/portals/2/documents/cneg8/anais/t12_0499_2465.pdf>. Acesso em 07 mai 2014.

TRIDAPALLI, Juarez Paulo; BORINELLI, Benilson. Compras Públicas: divergências de preços praticados entre os níveis de Governo e o mercado privado no Estado do Amazonas. VIII Congresso de Gestão Pública. Brasília. 2015. Disponível em:

<http://www.escoladegoverno.pr.gov.br/arquivos/File/2015/VIII_Consad/164.pdf>. Acesso em 15 jul 2015.

TRINDADE, Leandro L. Eficiência nas Compras Públicas. Jul. 2009. Disponível em:

<http://www.artigos.etc.br/eficiencia-nas-compras-publicas.html>. Acesso em: 14 mai. 2014.

VERGARA, S. C. Projetos e relatórios de pesquisa em administração. 3. Ed. São Paulo: Atlas, 2005.

VETTORATO, Gustavo. O conceito jurídico do princípio da eficiência da Administração pública. Diferenças com os princípios do bom administrador, razoabilidade e moralidade. 2001. Disponível em: < http://jus.com.br/artigos/4369/o-conceito-juridico-doprincipio-da-eficiencia-da-administracao-publica >. Acesso em: 6 maio 2014.

ZYLBERSZTAJN, Décio e NEVES, Marcos Fava. Economia e negocio agroindustrial. São Paulo: Pioneira, 2000. 


\section{ANEXO}

Tabela de Pregões da FUB homologados em 2011 e 2012.

\begin{tabular}{|c|c|c|c|c|c|c|c|c|c|c|c|c|c|}
\hline 产 & GRUPO DE MATERIAIS & ANO & $\begin{array}{l}\text { PE } \\
\text { ou } \\
\text { SRP }\end{array}$ & 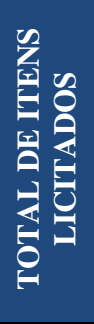 & 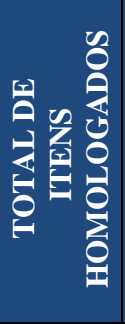 & 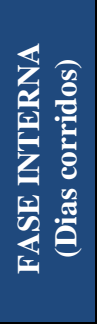 & 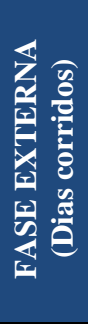 & 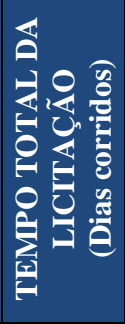 & 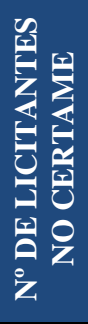 & 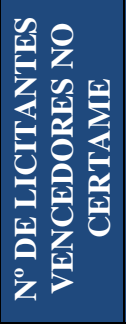 & $\begin{array}{l}\text { VLR. INICIAL } \\
\text { ESTIMADO }\end{array}$ & $\begin{array}{l}\text { VLR. TOTAL } \\
\text { HOMOLO- } \\
\text { GADO }\end{array}$ & $\begin{array}{c}\text { DIFERENÇA } \\
\text { ECONÔMICA } \\
\text { GERADA }\end{array}$ \\
\hline & \multicolumn{13}{|l|}{ GÊNEROS ALIMIENTÍCIOS } \\
\hline 001 & Arroz e farinha & 2011 & SRP & 2 & 2 & 29 & 26 & 55 & 19 & 1 & $173.916,00$ & $144.900,00$ & $29.016,00$ \\
\hline 026 & Café em pó e açúcar & 2011 & SRP & 2 & 1 & 56 & 108 & 164 & 24 & 1 & $56.100,00$ & $54.900,00$ & $1.200,00$ \\
\hline 011 & Café em pó & 2012 & SRP & 1 & 1 & 142 & 13 & 155 & 28 & 1 & $397.000,00$ & $196.000,00$ & $201.000,00$ \\
\hline 002 & $\begin{array}{l}\text { Condimentos, achocolatados, bebidas lácteas, } \\
\text { azeite, açúcar, cereais, conservas e café em pó }\end{array}$ & 2012 & SRP & 113 & 113 & 153 & 47 & 200 & 25 & 8 & $1.769 .939,21$ & $811.885,72$ & $958.053,49$ \\
\hline 038 & Água mineral & 2011 & SRP & 1 & 1 & 78 & 19 & 97 & 9 & 1 & $113.050,00$ & $103.253,50$ & $9.769,50$ \\
\hline 053 & Água mineral & 2012 & SRP & 1 & 1 & 77 & 7 & 84 & 12 & 1 & $150.500,00$ & $139.650,00$ & $10.850,00$ \\
\hline 024 & Concentrado líquido para refresco & 2012 & SRP & 10 & 10 & 271 & 23 & 294 & 4 & 1 & $555.379,31$ & $460.875,02$ & $94.504,29$ \\
\hline 097 & Pães e leite & 2011 & SRP & 6 & 6 & 169 & 21 & 190 & 5 & 1 & $116.907,30$ & $59.704,00$ & $57.203,30$ \\
\hline 089 & Pães e leite & 2012 & SRP & 6 & 6 & 154 & 72 & 226 & 5 & 3 & $104.598,00$ & $83.770,50$ & $20.827,50$ \\
\hline 004 & $\begin{array}{l}\text { Carnes suínas, bovinas, pescados, frios e } \\
\text { embutidos }\end{array}$ & 2012 & SRP & 24 & 24 & 153 & 27 & 180 & 15 & 4 & $4.237 .365,56$ & $2.325 .586,42$ & $1.911 .779,14$ \\
\hline 061 & $\begin{array}{l}\text { Carnes suínas, bovinas, pescados, frios e } \\
\text { embutidos }\end{array}$ & 2012 & $\mathrm{PE}$ & 23 & 23 & 71 & 124 & 195 & 12 & 5 & $4.070 .295,40$ & $2.995 .921,74$ & $1.074 .373,66$ \\
\hline
\end{tabular}




\begin{tabular}{|c|c|c|c|c|c|c|c|c|c|c|c|c|c|}
\hline 远 & GRUPO DE MATERIAIS & ANO & $\begin{array}{c}\text { PE } \\
\text { ou } \\
\text { SRP }\end{array}$ & 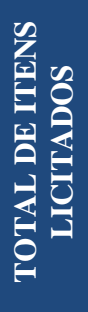 & 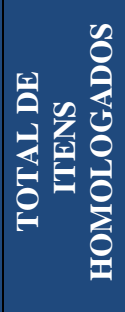 & 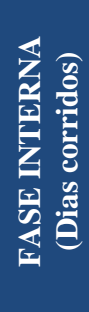 & 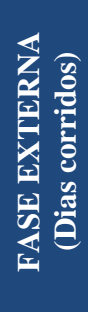 & 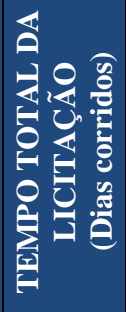 & 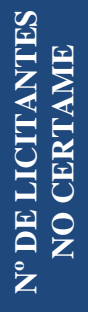 & 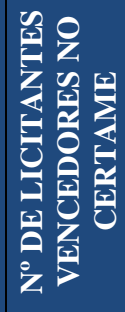 & $\begin{array}{l}\text { VLR. INICIAL } \\
\text { ESTIMADO }\end{array}$ & $\begin{array}{l}\text { VLR. TOTAL } \\
\text { HOMOLO- } \\
\text { GADO }\end{array}$ & $\begin{array}{c}\text { DIFERENÇA } \\
\text { ECONÔMICA } \\
\text { GERADA }\end{array}$ \\
\hline \multicolumn{14}{|c|}{ MATERIAL DE LAB./HOSPITALAR } \\
\hline 007 & Material de consumo p/laboratório & 2011 & SRP & 246 & 239 & 492 & 84 & 576 & 34 & 12 & $57.901,87$ & $91.758,56$ & ${ }^{+} 33.856,69$ \\
\hline 043 & Material de consumo p/laboratório & 2012 & SRP & 164 & 162 & 155 & 245 & 400 & 68 & 32 & $2.346 .374,13$ & $1.816 .741,20$ & $529.632,93$ \\
\hline 074 & Material de consumo p/laboratório & 2012 & SRP & 19 & 19 & 222 & 80 & 302 & 14 & 5 & $33.166,60$ & $27.294,53$ & $5.872,07$ \\
\hline 033 & Material de consumo p/laboratório & 2012 & PE & 105 & 86 & 433 & 48 & 481 & 9 & 4 & $26.623,65$ & $24.536,68$ & $2.086,97$ \\
\hline 039 & Material de consumo p/laboratório & 2012 & SRP & 93 & 5 & 99 & 179 & 278 & 18 & 10 & $254.201,85$ & $208.100,17$ & $46.101,68$ \\
\hline 010 & $\begin{array}{c}\text { Equipamentos para laboratório e simuladores } \\
\text { de ferida }\end{array}$ & 2011 & PE & 6 & 2 & 44 & 196 & 240 & 36 & 4 & $16.334,42$ & $16.707,49$ & ${ }^{+} \mathbf{3 7 3 , 0 7}$ \\
\hline 014 & $\begin{array}{l}\text { Material de consumo para laboratório, } \\
\text { medicamentos e produtos de uso veterinário }\end{array}$ & 2011 & SRP & 741 & 680 & 99 & 128 & 227 & 68 & 48 & $1.324 .289,71$ & $948.559,94$ & $375.729,77$ \\
\hline 065 & $\begin{array}{l}\text { Material de consumo para laboratório, } \\
\text { medicamentos e produtos de uso veterinário }\end{array}$ & 2012 & PE & 40 & 593 & 211 & 227 & 438 & 52 & 34 & $919.481,38$ & $860.847,57$ & $58.633,81$ \\
\hline 027 & Material descartável para laboratório & 2011 & PE & 38 & 28 & 29 & 29 & 58 & 4 & 2 & $8.767,60$ & $4.140,04$ & $4.627,56$ \\
\hline 032 & $\begin{array}{c}\text { Material de laboratório para o Centro de } \\
\text { Biotecnologia Molecular do IB }\end{array}$ & 2011 & PE & 95 & 89 & 124 & 52 & 176 & 26 & 14 & $149.890,47$ & $143.690,29$ & $6.200,18$ \\
\hline 036 & $\begin{array}{c}\text { Material de laboratório para o Programa } \\
\text { Universidade Aberta do Brasil }\end{array}$ & 2011 & $\mathrm{PE}$ & 39 & 39 & 91 & 44 & 135 & 19 & 8 & $51.219,29$ & $11.723,30$ & $39.495,99$ \\
\hline 043 & $\begin{array}{c}\text { Material de laboratório para o Laboratório } \\
\text { Multidisciplinar da FCE }\end{array}$ & 2011 & SRP & 75 & 67 & 285 & 121 & 406 & 19 & 15 & $32.595,63$ & $155.082,86$ & ${ }^{+} 122.487,23$ \\
\hline 072 & Kits (10) com três micropipetas ajustáveis & 2011 & $\mathrm{PE}$ & 1 & 1 & 51 & 20 & 71 & 13 & 1 & $11.367,00$ & $95.500,00$ & ${ }^{+} 84.133,00$ \\
\hline
\end{tabular}




\begin{tabular}{|c|c|c|c|c|c|c|c|c|c|c|c|c|c|}
\hline 疍 & GRUPO DE MATERIAIS & ANO & $\begin{array}{l}\text { PE } \\
\text { ou } \\
\text { SRP }\end{array}$ & 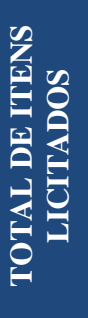 & 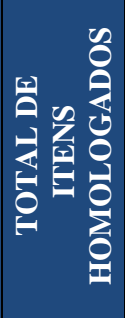 & 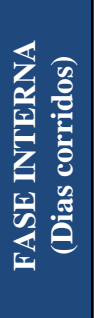 & 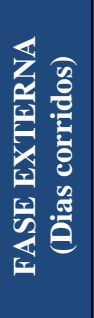 & 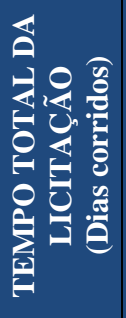 & 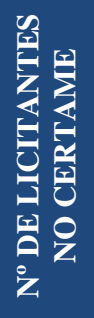 & 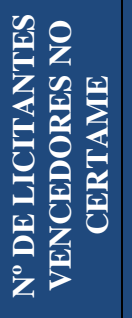 & $\begin{array}{l}\text { VLR. INICIAL } \\
\text { ESTIMADO }\end{array}$ & $\begin{array}{l}\text { VLR. TOTAL } \\
\text { HOMOLO- } \\
\text { GADO }\end{array}$ & $\begin{array}{l}\text { DIFERENÇA } \\
\text { ECONÔMICA } \\
\text { GERADA }\end{array}$ \\
\hline 044 & $\begin{array}{l}\text { Maravalha de pinus seco para utilização nas } \\
\text { baias dos animais do HVET }\end{array}$ & 2012 & SRP & 1 & 1 & 156 & 34 & 190 & 15 & 1 & $57.166,67$ & $59.000,00$ & ${ }^{+} 1.833,33$ \\
\hline 056 & \multirow{2}{*}{$\begin{array}{l}\text { Material de consumo para o HVET } \\
\text { Milho em grão para a confecção de ração } \\
\text { animal }\end{array}$} & 2012 & SRP & 50 & 49 & 547 & 54 & 601 & 8 & 6 & $10.063,45$ & $8.635,32$ & $1.428,13$ \\
\hline 083 & & 2012 & SRP & 1 & 1 & 43 & 18 & 61 & 11 & 1 & $82.600,00$ & $69.840,00$ & $12.760,00$ \\
\hline \multicolumn{14}{|c|}{$\begin{array}{l}\text { MATERIAL DE EXPEDIENTE } \\
\text { MOBILIÁRIO / LIMPEZA } \\
\end{array}$} \\
\hline 018 & $\begin{array}{l}\text { Material de expediente p/o curso de } \\
\text { licenciatura em educação física }\end{array}$ & 2011 & PE & 13 & 9 & 52 & 18 & 70 & 4 & 3 & $7.832,62$ & $6.651,90$ & $1.180,72$ \\
\hline 022 & Material de expediente & 2011 & SRP & 151 & 114 & 29 & 65 & 94 & 12 & 7 & $17.286,03$ & $13.237,66$ & $4.048,37$ \\
\hline 039 & Mobiliário & 2011 & PE & 1 & 1 & 34 & 29 & 63 & 41 & 1 & $205.400,00$ & $63.550,00$ & $141.850,00$ \\
\hline 028 & Banquetas para laboratório & 2012 & $\mathrm{PE}$ & 1 & 1 & 138 & 24 & 162 & 22 & 1 & $24.336,79$ & $17.524,00$ & $6.812,79$ \\
\hline 036 & Banquetas para microscópio & 2012 & $\mathrm{PE}$ & 2 & 2 & 87 & 20 & 107 & 23 & 1 & $23.000,00$ & $7.406,00$ & $15.594,00$ \\
\hline 060 & $\begin{array}{l}\text { Material de expediente, escritório, limpeza, } \\
\text { higiene, descartáveis e informática }\end{array}$ & 2011 & SRP & 615 & 610 & 100 & 121 & 221 & 153 & 73 & $19.035 .728,99$ & $12.020 .215,33$ & $7.015 .513,66$ \\
\hline 001 & Material de limpeza & 2012 & SRP & 57 & 57 & 162 & 42 & 204 & 59 & 14 & $439.319,72$ & $651.255,72$ & ${ }^{+} 211.936,00$ \\
\hline 030 & Material de limpeza & 2012 & SRP & 8 & 8 & 248 & 39 & 287 & 33 & 3 & $82.939,63$ & $20.301,80$ & $62.637,83$ \\
\hline 071 & Lixeiras com dois compartimentos & 2012 & $\mathrm{PE}$ & 1 & 1 & 89 & 166 & 255 & 15 & 1 & $104.344,17$ & $71.725,00$ & $32.619,17$ \\
\hline \multicolumn{14}{|c|}{ MATERIAL DE CONSTRUÇÃO } \\
\hline 003 & $\begin{array}{c}\text { Material de construção, reforma, acabamento } \\
\text { e limpeza }\end{array}$ & 2011 & SRP & 525 & 515 & 269 & 81 & 350 & 35 & 21 & $507.107,93$ & $340.528,93$ & $166.579,00$ \\
\hline 046 & Material hidráulico & 2011 & SRP & 476 & 476 & 119 & 198 & 227 & 26 & 17 & $587.151,10$ & $405.151,10$ & $181.963,00$ \\
\hline
\end{tabular}




\begin{tabular}{|c|c|c|c|c|c|c|c|c|c|c|c|c|c|}
\hline 言 & GRUPO DE MATERIAIS & ANO & $\begin{array}{l}\text { PE } \\
\text { ou } \\
\text { SRP }\end{array}$ & 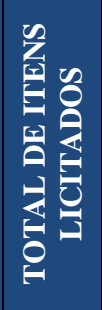 & 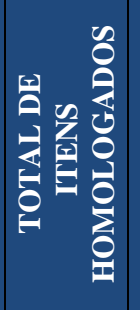 & 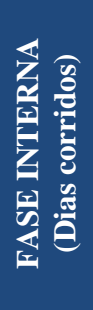 & 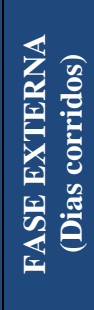 & 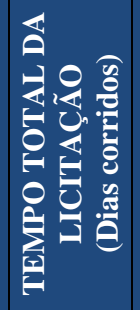 & 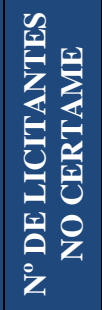 & 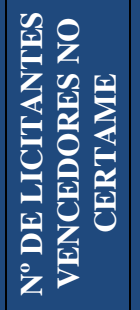 & $\begin{array}{l}\text { VLR. INICIAL } \\
\text { ESTIMADO }\end{array}$ & $\begin{array}{l}\text { VLR. TOTAL } \\
\text { HOMOLO- } \\
\text { GADO }\end{array}$ & $\begin{array}{l}\text { DIFERENÇA } \\
\text { ECONÔMICA } \\
\text { GERADA }\end{array}$ \\
\hline 119 & Material hidráulico & 2012 & SRP & 520 & 516 & 263 & 96 & 359 & 43 & 21 & $4.372 .572,58$ & $3.574 .048,50$ & $798.524,08$ \\
\hline 047 & Material de alvenaria & 2011 & SRP & 95 & 95 & 48 & 51 & 99 & 20 & 15 & $1.292 .319,00$ & $1.569 .880,65$ & ${ }^{+} 277.561,65$ \\
\hline 087 & Material de alvenaria & 2012 & SRP & 116 & 116 & 253 & 52 & 305 & 32 & 22 & $9.154 .195,33$ & $2.877 .472,30$ & $6.276 .723,03$ \\
\hline 048 & Material de carpintaria & 2011 & SRP & 398 & 398 & 130 & 97 & 227 & 35 & 22 & $5.493 .996,70$ & $2.791 .406,83$ & $2.702 .589,87$ \\
\hline 118 & Material de carpintaria & 2012 & SRP & 480 & 479 & 294 & 65 & 359 & 42 & 25 & $32.402 .876,00$ & $11.865 .702,45$ & $20.537 .173,55$ \\
\hline 049 & Material elétrico & 2011 & SRP & 399 & 398 & 106 & 202 & 308 & 53 & 33 & $3.776 .827,52$ & $2.062 .628,30$ & $1.714 .199,22$ \\
\hline 120 & Material elétrico & 2012 & SRP & 453 & 453 & 325 & 90 & 415 & 67 & 29 & $8.535 .643,25$ & $11.375 .918,45$ & ${ }^{+} 2.840 .275,20$ \\
\hline 037 & Material de iluminação p/ANF-09 & 2012 & $\mathrm{PE}$ & 8 & 2 & 140 & 48 & 188 & 11 & 3 & $15.732,63$ & $15.322,08$ & 410,55 \\
\hline 051 & Material de parques e jardins & 2011 & SRP & 106 & 106 & 122 & 105 & 227 & 24 & 14 & $629.145,06$ & $508.938,56$ & $120.206,50$ \\
\hline 052 & Material de pintura & 2011 & SRP & 139 & 139 & 134 & 126 & 260 & 28 & 16 & $855.326,70$ & $600.324,60$ & $255.002,10$ \\
\hline 116 & Material de pintura & 2012 & SRP & 102 & 102 & 331 & 86 & 417 & 41 & 15 & $1.751 .447,67$ & $1.135 .960,20$ & $615.487,47$ \\
\hline 110 & Material de serralheria e marcenaria & 2012 & SRP & 433 & 431 & 328 & 50 & 378 & 43 & 25 & $4.595 .943,12$ & $2.260 .551,16$ & 2.335.391,96 \\
\hline 092 & Fios, isolantes e cabos elétricos & 2011 & SRP & 23 & 23 & 307 & 33 & 340 & 9 & 4 & $24.770,03$ & $19.065,17$ & $5.704,86$ \\
\hline 042 & Cabos e tampas com 2 módulos & 2012 & SRP & 3 & 3 & 60 & 36 & 96 & 23 & 2 & $38.220,00$ & $4.310,00$ & $33.910,00$ \\
\hline 117 & Material de telefonia & 2012 & SRP & 113 & 112 & 282 & 68 & 350 & 20 & 13 & $9.658 .227,20$ & $4.203 .873,00$ & $5.454 .354,20$ \\
\hline
\end{tabular}

Material específico para o curso de Terapia Ocupacional

$\begin{array}{lllllll}2011 & \text { PE } & 13 & 13 & 72 & 81 & 153\end{array}$

$16.530,58$

$18.190,27$

${ }^{+} 1.659 .69$

MATERIAIS DE CONSUMO DIVERSOS

$\begin{array}{ccccccccccccccc}045 & \begin{array}{c}\text { Pallets (300) em plástico injetado em } \\ \text { polipropileno }\end{array} & 2011 & \text { PE } & 1 & 1 & 109 & 19 & 128 & 27 & 1 & 33.210,00 & 38.000,00 & { }^{+} \mathbf{4 . 7 9 0 , 0 0} \\ 053 & \text { Ferramentaria } & 2011 & \text { SRP } & 111 & 111 & 127 & 100 & 227 & 25 & 14 & 321.651,75 & 263.328,82 & 58.322,93\end{array}$




\begin{tabular}{|c|c|c|c|c|c|c|c|c|c|c|c|c|c|}
\hline 产 & GRUPO DE MATERIAIS & ANO & $\begin{array}{l}\text { PE } \\
\text { ou } \\
\text { SRP }\end{array}$ & 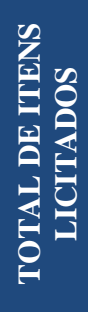 & 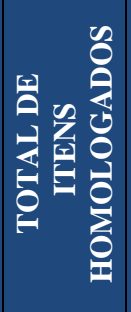 & 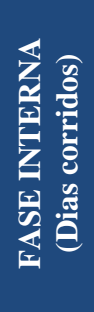 & 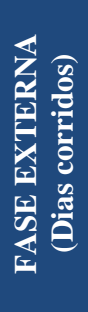 & 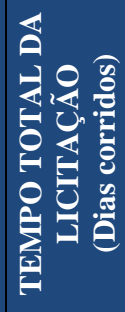 & 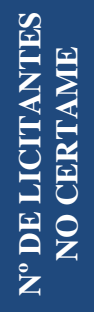 & 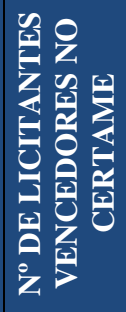 & $\begin{array}{l}\text { VLR. INICIAL } \\
\text { ESTIMADO }\end{array}$ & $\begin{array}{l}\text { VLR. TOTAL } \\
\text { HOMOLO- } \\
\text { GADO }\end{array}$ & $\begin{array}{l}\text { DIFERENÇA } \\
\text { ECONÔMICA } \\
\text { GERADA }\end{array}$ \\
\hline 063 & $\begin{array}{l}\text { Material para manutenção em } 500 \text { bebedouros } \\
\text { tipo BAG- } 80\end{array}$ & 2011 & $\mathrm{PE}$ & 11 & 11 & 204 & 20 & 224 & 11 & 4 & $33.805,83$ & $14.538,99$ & $19.266,84$ \\
\hline 064 & $\begin{array}{c}\text { Matéria prima para fabricação de saneantes na } \\
\text { Fábrica Escola de Química }\end{array}$ & 2011 & SRP & 46 & 46 & 196 & 40 & 236 & 7 & 2 & $174.311,92$ & $168.459,83$ & $5.852,09$ \\
\hline 069 & Baterias de chumbo & 2011 & PE & 2 & 2 & 134 & 14 & 148 & 13 & 2 & $61.968,00$ & $57.099,00$ & $4.869,00$ \\
\hline 081 & Peças, partes e ferramentas para o CME & 2011 & SRP & 123 & 123 & 299 & 38 & 337 & 3 & 1 & $123.508,66$ & $158.364,00$ & ${ }^{+} 34.855,34$ \\
\hline 101 & Ferramentas manuais para o CME & 2011 & SRP & 428 & 291 & 99 & 61 & 160 & 11 & 6 & $85.909,65$ & $72.057,55$ & $13.852,10$ \\
\hline 019 & Sensores para aparelho de hemogasometria & 2012 & SRP & 8 & 8 & 146 & 57 & 203 & 2 & 1 & $13.416,57$ & $12.836,75$ & 579,82 \\
\hline 016 & Molas e kit de ferragens para portas & 2012 & $\mathrm{PE}$ & 3 & 3 & 73 & 10 & 83 & 13 & 1 & $24.993,30$ & $12.074,60$ & $12.918,70$ \\
\hline 034 & Capachos, persianas e películas & 2012 & SRP & 10 & 10 & 179 & 135 & 314 & 29 & 5 & $1.107 .506,79$ & $491.710,35$ & $615.796,44$ \\
\hline 040 & Canecas e ecobags & 2012 & $\mathrm{PE}$ & 3 & 3 & 140 & 45 & 185 & 58 & 3 & $142.690,00$ & $50.035,00$ & $92.655,00$ \\
\hline 051 & $\begin{array}{l}\text { Cola de contato e placas de compensado } \\
\text { naval }\end{array}$ & 2012 & PE & 2 & 2 & 394 & 35 & 429 & 13 & 2 & $18.752,25$ & $20.240,00$ & ${ }^{+} 1.487,75$ \\
\hline 096 & $\begin{array}{l}\text { Material de consumo para microfilmagem de } \\
\text { documentos }\end{array}$ & 2012 & SRP & 9 & 5 & 427 & 83 & 510 & 3 & 1 & $30.135,92$ & $16.382,00$ & $13.753,92$ \\
\hline \multicolumn{14}{|c|}{ EQUIPAMIENTOS DIVERSOS } \\
\hline 015 & $\begin{array}{c}\text { Equipamentos de laboratório p/o Centro de } \\
\text { Estudos do Cerrado da Chapada dos } \\
\text { Veadeiros }\end{array}$ & 2011 & $\mathrm{PE}$ & 18 & 18 & 48 & 122 & 170 & 58 & 9 & $229.269,79$ & $118.296,98$ & $110.972,81$ \\
\hline 034 & Purificadores de água e elementos filtrantes & 2011 & SRP & 4 & 4 & 144 & 75 & 219 & 49 & 1 & $180.633,00$ & $178.023,00$ & $2.610,00$ \\
\hline
\end{tabular}




\begin{tabular}{|c|c|c|c|c|c|c|c|c|c|c|c|c|c|}
\hline 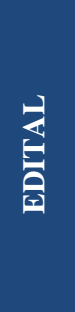 & GRUPO DE MATERIAIS & ANO & $\begin{array}{l}\text { PE } \\
\text { ou } \\
\text { SRP }\end{array}$ & 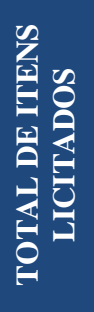 & 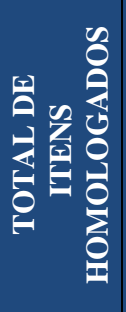 & 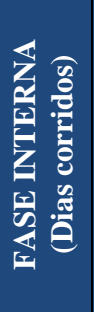 & 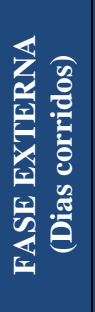 & 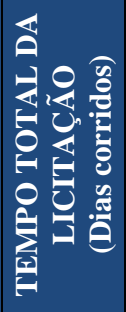 & 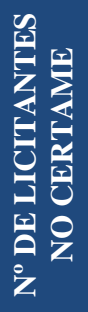 & 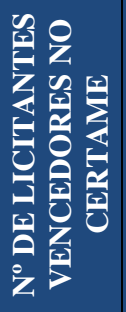 & $\begin{array}{l}\text { VLR. INICIAL } \\
\text { ESTIMADO }\end{array}$ & $\begin{array}{l}\text { VLR. TOTAL } \\
\text { HOMOLO- } \\
\text { GADO }\end{array}$ & $\begin{array}{l}\text { DIFERENÇA } \\
\text { ECONÔMICA } \\
\text { GERADA }\end{array}$ \\
\hline 054 & $\begin{array}{l}\text { Fotômetro de chama digital, filtro de cálcio, } \\
\text { espectrofotômetro, medidor de PH de bancada } \\
\text { e chapa aquecedora }\end{array}$ & 2011 & PE & 5 & 5 & 357 & 52 & 409 & 31 & 4 & $23.835,33$ & $15.183,00$ & $8.652,33$ \\
\hline 059 & $\begin{array}{l}\text { Equipamentos para os laboratórios de } \\
\text { fisiologia e cine antropometria da FEF }\end{array}$ & 2011 & PE & 9 & 9 & 4 & 52 & 56 & 19 & 8 & $15.832,81$ & $18.781,76$ & ${ }^{+} \mathbf{2 . 9 4 8 , 9 5}$ \\
\hline 068 & $\begin{array}{l}\text { Equipamentos de hidrossedimentométricos } \\
\text { para amostragem e medição de sedimentos } \\
\text { em suspensão e carga de fundo para o IG }\end{array}$ & 2011 & $\mathrm{PE}$ & 3 & 3 & 77 & 8 & 85 & 11 & 2 & $15.567,66$ & $14.281,00$ & $1.286,66$ \\
\hline 076 & Eletrocardiógrafo (2) portátil & 2011 & $\mathrm{PE}$ & 1 & 1 & 91 & 14 & 105 & 11 & 1 & $14.300,00$ & $6.520,00$ & $7.780,00$ \\
\hline 079 & Equipamentos de laboratório para a FUP & 2011 & $\mathrm{PE}$ & 24 & 22 & 61 & 35 & 96 & 85 & 13 & $170.159,03$ & $111.599,04$ & $58.559,99$ \\
\hline 084 & $\begin{array}{l}\text { Equipamentos para o laboratório } \\
\text { multiprofissional de habilidades }\end{array}$ & 2011 & $\mathrm{PE}$ & 11 & 11 & 78 & 10 & 88 & 10 & 3 & $76.626,32$ & $60.690,00$ & $15.936,32$ \\
\hline 087 & $\begin{array}{l}\text { Mesa agitadora orbital para análise de solos e } \\
\text { determinação de nitrogênio }\end{array}$ & 2011 & $\mathrm{PE}$ & 2 & 2 & 161 & 21 & 182 & 14 & 2 & $21.611,56$ & $18.499,90$ & $3.111,66$ \\
\hline 088 & $\begin{array}{l}\text { Manequins, simuladores de partes humanas, } \\
\text { microscópio, bisturi de volatização celular e } \\
\text { mobiliário hospitalar }\end{array}$ & 2011 & PE & 21 & 18 & 128 & 4 & 132 & 35 & 9 & $140.698,00$ & $120.954,00$ & $19.744,00$ \\
\hline 095 & Aparelhos de ar condicionado & 2011 & SRP & 17 & 17 & 65 & 105 & 170 & 24 & 3 & $10.522 .666,00$ & $6.822 .575,96$ & $3.700 .090,04$ \\
\hline 029 & $\begin{array}{l}\text { Extrator de gordura e moinho tipo ciclone } \\
\text { para grãos }\end{array}$ & 2012 & PE & 2 & 2 & 365 & 49 & 414 & 12 & 1 & $15.642,67$ & $9.979,98$ & $5.662,69$ \\
\hline
\end{tabular}




\begin{tabular}{|c|c|c|c|c|c|c|c|c|c|c|c|c|c|}
\hline 育 & GRUPO DE MATERIAIS & ANO & $\begin{array}{l}\text { PE } \\
\text { ou } \\
\text { SRP }\end{array}$ & 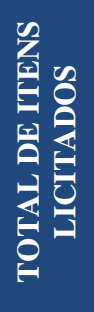 & 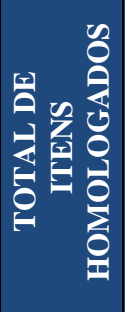 & 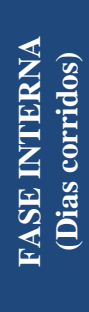 & 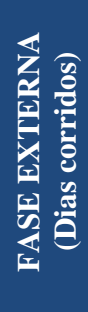 & 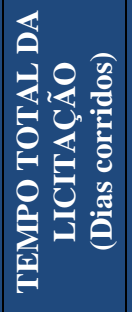 & 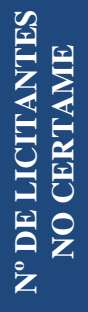 & 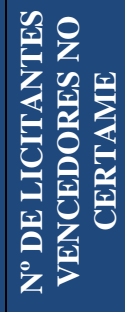 & $\begin{array}{l}\text { VLR. INICIAL } \\
\text { ESTIMADO }\end{array}$ & $\begin{array}{l}\text { VLR. TOTAL } \\
\text { HOMOLO- } \\
\text { GADO }\end{array}$ & $\begin{array}{l}\text { DIFERENÇA } \\
\text { ECONÔMICA } \\
\text { GERADA }\end{array}$ \\
\hline 031 & $\begin{array}{l}\text { Plataforma de laboratório para o } \\
\text { Departamento de Eng. Elétrica }\end{array}$ & 2012 & PE & 1 & 1 & 4 & 21 & 25 & 4 & 1 & $153.151,20$ & $152.960,00$ & 191,20 \\
\hline 045 & Digitalizador de imagem & 2012 & $\mathrm{PE}$ & 1 & 1 & 14 & 15 & 29 & 7 & 1 & $26.849,32$ & $25.985,00$ & 864,32 \\
\hline 055 & Conjunto de câmara-fria & 2012 & SRP & 6 & 6 & 271 & 93 & 364 & 4 & 3 & $65.143,20$ & $57.180,00$ & $7.963,20$ \\
\hline 085 & Mesa cirúrgica & 2012 & $\mathrm{PE}$ & 1 & 1 & 243 & 35 & 278 & 7 & 1 & $66.633,30$ & $66.300,00$ & 333,30 \\
\hline 114 & Circo oval para o DEA & 2012 & PE & 1 & 1 & 371 & 6 & 377 & 88 & 1 & $72.722,67$ & $41.800,00$ & $30.922,67$ \\
\hline \multicolumn{14}{|c|}{ MATERIAL ESPORTIVO / GINÁSTICA } \\
\hline 093 & $\begin{array}{c}\text { Equipamentos de ginástica para as atividades } \\
\text { de ensino do curso de Licenciatura em } \\
\text { Educação Física }\end{array}$ & 2011 & $\mathrm{PE}$ & 3 & 3 & 412 & 8 & 420 & 7 & 2 & $13.811,63$ & $10.128,00$ & $3.683,63$ \\
\hline 022 & Material esportivo & 2012 & SRP & 26 & 26 & 431 & 185 & 616 & 20 & 1 & $260.983,33$ & $191.342,30$ & $69.641,03$ \\
\hline 069 & Material esportivo & 2012 & $\mathrm{PE}$ & 40 & 40 & 266 & 68 & 334 & 16 & 8 & $75.338,40$ & $32.590,50$ & $42.747,90$ \\
\hline 073 & Material esportivo & 2012 & SRP & 44 & 44 & 64 & 134 & 198 & 26 & 10 & $175.851,64$ & $111.802,71$ & $64.048,93$ \\
\hline \multicolumn{14}{|c|}{$\begin{array}{l}\text { EQUIPAMENTOS, INSUMOS DE } \\
\text { INFORMÁTICA / ÁUDIO }\end{array}$} \\
\hline 056 & Material de áudio e informática & 2011 & PE & 4 & 4 & 295 & 42 & 337 & 41 & 2 & $183.033,34$ & $102.448,88$ & $80.584,46$ \\
\hline 061 & $\begin{array}{c}\text { Microcomputadores (25) e licenças Windows } \\
7 \text { professional (25) }\end{array}$ & 2011 & $\mathrm{PE}$ & 2 & 2 & 143 & 18 & 161 & 56 & 2 & $54.866,66$ & $36.402,00$ & $18.464,66$ \\
\hline 070 & Microcomputador servidor (01) & 2011 & $\mathrm{PE}$ & 1 & 1 & 453 & 8 & 461 & 13 & 1 & $25.594,73$ & $29.900,00$ & ${ }^{+} 4.305,27$ \\
\hline 048 & Microcomputador (03) & 2012 & $\mathrm{PE}$ & 3 & 3 & 246 & 14 & 260 & 18 & 1 & $15.639,33$ & $13.769,00$ & $1.870,33$ \\
\hline 109 & Microcomputador (100) & 2012 & SRP & 1 & 1 & 125 & 80 & 205 & 39 & 1 & $598.267,00$ & $478.990,00$ & $119.277,00$ \\
\hline 073 & Equipamento de áudio visual & 2011 & PE & 76 & 75 & 125 & 121 & 246 & 108 & 37 & $18.258 .249,60$ & $11.188 .218,48$ & $7.070 .013,12$ \\
\hline
\end{tabular}




\begin{tabular}{|c|c|c|c|c|c|c|c|c|c|c|c|c|c|}
\hline 言 & GRUPO DE MATERIAIS & ANO & $\begin{array}{l}\text { PE } \\
\text { ou } \\
\text { SRP }\end{array}$ & 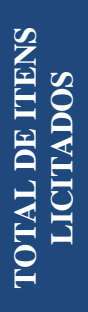 & 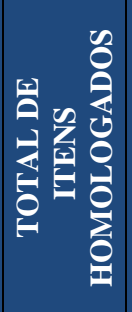 & 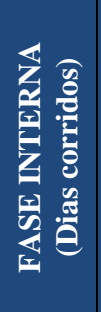 & 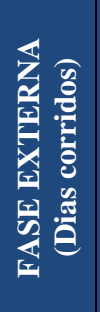 & 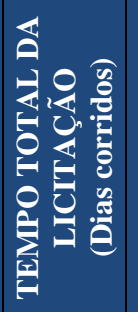 & 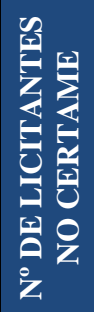 & 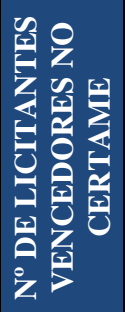 & $\begin{array}{l}\text { VLR. INICIAL } \\
\text { ESTIMADO }\end{array}$ & $\begin{array}{l}\text { VLR. TOTAL } \\
\text { HOMOLO- } \\
\text { GADO }\end{array}$ & $\begin{array}{l}\text { DIFERENÇA } \\
\text { ECONÔMICA } \\
\text { GERADA }\end{array}$ \\
\hline 035 & Equipamento de áudio visual & 2012 & SRP & 28 & 18 & 63 & 371 & 434 & 69 & 14 & $1.587 .473,50$ & $994.236,60$ & $593.236,90$ \\
\hline 050 & Equipamento de áudio visual & 2012 & PE & 1 & 1 & 363 & 35 & 398 & 2 & 1 & $16.683,33$ & $13.000,00$ & $3.683,33$ \\
\hline 078 & $\begin{array}{l}\text { Softwares, cabo de antena, sensores e } \\
\text { cartucho para impressora }\end{array}$ & 2011 & PE & 5 & 5 & 85 & 12 & 97 & 16 & 4 & $140.113,26$ & $122.227,00$ & $17.886,26$ \\
\hline 121 & Cartuchos e toners para impressora & 2012 & SRP & 60 & 55 & 261 & 126 & 387 & 71 & 18 & $12.776 .010,00$ & $2.880 .115,00$ & $9.895 .895,00$ \\
\hline 085 & $\begin{array}{l}\text { Material de informática, máquinas } \\
\text { fotográficas e outros }\end{array}$ & 2011 & PE & 14 & 14 & 169 & 43 & 212 & 22 & 8 & $61.098,32$ & $24.835,99$ & $36.262,33$ \\
\hline 096 & Projetores de multimídia e telas de projeção & 2011 & SRP & 10 & 10 & 155 & 129 & 284 & 42 & 5 & $3.712 .400,00$ & $2.313 .142,00$ & $1.399 .258,00$ \\
\hline 102 & $\begin{array}{c}\text { Equipamentos eletrônicos e acessórios de } \\
\text { áudio }\end{array}$ & 2011 & SRP & 19 & 19 & 323 & 36 & 359 & 30 & 6 & $179.387,75$ & $106.170,32$ & $73.217,43$ \\
\hline 101 & $\begin{array}{c}\text { Multímetro digital, alicate amperímetro, ferro } \\
\text { de solda, lupa de bancada, sugador de solda, } \\
\text { bateria, parafusadeira, soprador/aspirador e } \\
\text { disjuntor bipolar }\end{array}$ & 2012 & SRP & 12 & 12 & 52 & 92 & 144 & 42 & 09 & $42.120,55$ & $32.300,27$ & $9.820,28$ \\
\hline 100 & Equipamentos de informática & 2011 & PE & 39 & 28 & 21 & 7 & 28 & 50 & 17 & $483.365,66$ & $425.882,32$ & $57.483,34$ \\
\hline 072 & Equipamentos de informática & 2012 & PE & 3 & 2 & 390 & 147 & 537 & 9 & 2 & $6.649,00$ & $9.091,00$ & ${ }^{+} \mathbf{2 . 4 4 2 , 0 0}$ \\
\hline & $\begin{array}{l}\text { MANUTENÇÃO DE MÁQUINAS E } \\
\text { EQUIPAMENTOS }\end{array}$ & & & & & & & & & & & & \\
\hline 047 & $\begin{array}{l}\text { Manutenção de equipamentos de } \\
\text { microfilmagem }\end{array}$ & 2012 & $\mathrm{PE}$ & 7 & 7 & 95 & 6 & 101 & 3 & 1 & $11.065,00$ & $9.585,00$ & $1.480,00$ \\
\hline 052 & Manutenção de arquivos fixos & 2012 & PE & 1 & 1 & 186 & 27 & 213 & 6 & 1 & $9.318,33$ & $1.290,00$ & $8.028,33$ \\
\hline 107 & Manutenção em cancelas/portas do RU & 2012 & $\mathrm{PE}$ & 4 & 4 & 304 & 22 & 326 & 2 & 1 & $18.982,38$ & $18.965,79$ & 16,59 \\
\hline
\end{tabular}




\begin{tabular}{|c|c|c|c|c|c|c|c|c|c|c|c|c|c|}
\hline 胥 & GRUPO DE MATERIAIS & ANO & $\begin{array}{l}\text { PE } \\
\text { ou } \\
\text { SRP }\end{array}$ & 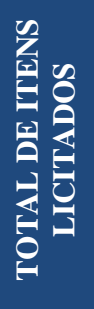 & 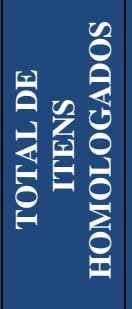 & 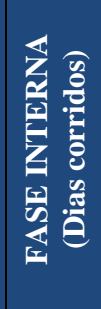 & 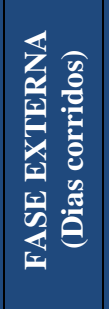 & 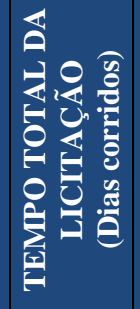 & 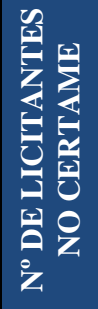 & 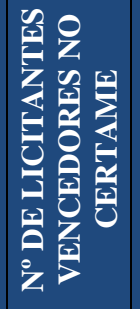 & $\begin{array}{l}\text { VLR. INICIAL } \\
\text { ESTIMADO }\end{array}$ & $\begin{array}{l}\text { VLR. TOTAL } \\
\text { HOMOLO- } \\
\text { GADO }\end{array}$ & $\begin{array}{l}\text { DIFERENÇA } \\
\text { ECONÔMICA } \\
\text { GERADA }\end{array}$ \\
\hline \multicolumn{14}{|c|}{$\begin{array}{l}\text { MÁQUINAS / EQUIPAMENTOS E } \\
\text { INSUMOS AGRÍCOLAS }\end{array}$} \\
\hline 057 & Insumos agrícolas para a FAL & 2011 & SRP & 69 & 47 & 85 & 27 & 112 & 16 & 10 & $348.807,59$ & $212.577,90$ & $136.229,69$ \\
\hline 057 & Insumos agrícolas para a FAL & 2012 & SRP & 15 & 15 & 69 & 400 & 469 & 21 & 7 & $662.088,33$ & $468.910,50$ & $193.177,83$ \\
\hline 009 & $\begin{array}{l}\text { Máquinas e equipamentos agrícolas para a } \\
\text { FAL }\end{array}$ & 2011 & PE & 23 & 21 & 335 & 41 & 376 & 40 & 3 & $955.046,83$ & $809.182,99$ & $145.863,86$ \\
\hline 062 & $\begin{array}{c}\text { Máquinas e equipamentos agrícolas para a } \\
\text { FAL }\end{array}$ & 2011 & PE & 7 & 6 & 430 & 26 & 456 & 14 & 3 & $439.900,37$ & $334.459,50$ & $105.440,87$ \\
\hline 059 & $\begin{array}{c}\text { Máquinas e equipamentos agrícolas para a } \\
\text { FAL }\end{array}$ & 2012 & SRP & 10 & 10 & 96 & 41 & 137 & 41 & 5 & $337.649,18$ & $314.534,44$ & $23.114,74$ \\
\hline \multicolumn{14}{|c|}{ INSTRUMENTOS MUSICAIS } \\
\hline 044 & $\begin{array}{l}\text { Clavinova (02), prato de shimbal de } 14 "(01), \\
\text { prato de condução de } 20 "(01) \text {, prato de } \\
\text { ataque de } 16 \text { " }(01), \text { bateria acústica }(01) \text { e } \\
\text { amplificador de som }(02)\end{array}$ & 2011 & PE & 6 & 6 & 98 & 36 & 134 & 10 & 3 & $14.794,50$ & $7.917,08$ & $6.877,42$ \\
\hline 055 & $\begin{array}{l}\text { Microfone (06), pedestal (01), violão (01), } \\
\text { teclado (01), suporte p/teclado (10), estantes } \\
\text { p/partituras (40), adaptador de áudio ( } 20)\end{array}$ & 2011 & PE & 15 & 15 & 107 & 54 & 161 & 15 & 6 & $11.219,66$ & $8.546,10$ & $2.673,56$ \\
\hline 026 & Instrumentos e equipamentos musicais & 2012 & PE & 48 & 43 & 105 & 270 & 375 & 21 & 7 & $45.083,12$ & $30.151,66$ & $14.931,46$ \\
\hline \multicolumn{14}{|c|}{ PASSAGENS } \\
\hline 005 & Passagens & 2012 & SRP & 6 & 6 & 30 & 27 & 57 & 19 & 1 & $23.256 .333,33$ & $20.261 .899,00$ & $2.994 .434,33$ \\
\hline
\end{tabular}




\begin{tabular}{|c|c|c|c|c|c|c|c|c|c|c|c|c|c|}
\hline 晃 & GRUPO DE MATERIAIS & ANO & $\begin{array}{l}\text { PE } \\
\text { ou } \\
\text { SRP }\end{array}$ & 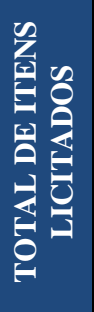 & 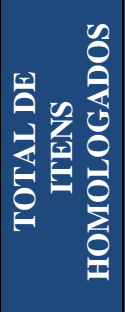 & 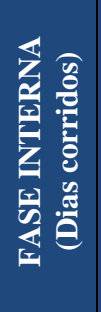 & 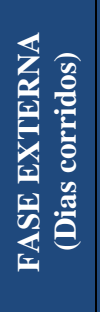 & 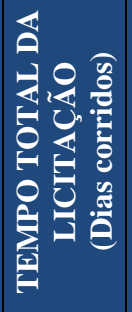 & 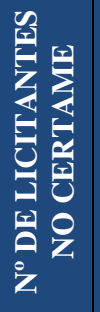 & 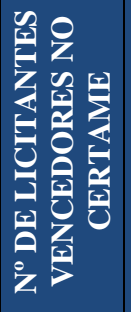 & $\begin{array}{l}\text { VLR. INICIAL } \\
\text { ESTIMADO }\end{array}$ & $\begin{array}{l}\text { VLR. TOTAL } \\
\text { HOMOLO- } \\
\text { GADO }\end{array}$ & $\begin{array}{c}\text { DIFERENÇA } \\
\text { ECONÔMICA } \\
\text { GERADA }\end{array}$ \\
\hline 005 & $\begin{array}{l}\text { Serviços gráficos para confecção de livros, } \\
\text { cartilhas, cartazes, folder's, banner's e outros }\end{array}$ & 2011 & SRP & 40 & 40 & 44 & 22 & 66 & 27 & 2 & $3.079 .422,10$ & $1.563 .510,00$ & $1.515 .912,00$ \\
\hline 018 & $\begin{array}{c}\text { Confecção de certificados de especialização e } \\
\text { extensão }\end{array}$ & 2012 & SRP & 2 & 2 & 88 & 15 & 103 & 10 & 1 & $122.300,00$ & $62.825,00$ & $59.475,00$ \\
\hline 104 & $\begin{array}{l}\text { Serviços gráficos p/fornecimento de pastas } \\
\text { em papel, pastas em couro, envelopes, } \\
\text { convites, certificados, diplomas em } \\
\text { pergaminho animal, nominatas, cartões de } \\
\text { mesas e canudos para formatura }\end{array}$ & 2012 & SRP & 10 & 10 & 118 & 39 & 157 & 25 & 6 & $187.623,30$ & $303.882,00$ & ${ }^{+} 116.258,70$ \\
\hline 024 & $\begin{array}{c}\text { Serviços gráficos para confecção de } 30.000 \\
\text { certificados }\end{array}$ & 2011 & $\mathrm{PE}$ & 1 & 1 & 24 & 38 & 62 & 5 & 1 & $39.000,00$ & $26.799,00$ & $12.201,00$ \\
\hline 025 & $\begin{array}{c}\text { Confecção de } 1.100 \text { exemplares da revista } \\
\text { Psicologia: Teoria e Pesquisa }\end{array}$ & 2011 & $\mathrm{PE}$ & 1 & 1 & 142 & 18 & 160 & 26 & 1 & $27.866,66$ & $10.485,00$ & $17.381,66$ \\
\hline 083 & $\begin{array}{l}\text { Revisão, diagramação, editoração, impressão, } \\
\text { acabamento e publicação de serviços gráficos }\end{array}$ & 2011 & $\mathrm{PE}$ & 1 & 1 & 72 & 14 & 86 & 18 & 1 & $156.666,66$ & $155.980,00$ & 686,66 \\
\hline 099 & Encadernação de livros da BCE & 2011 & $\mathrm{PE}$ & 1 & 1 & 93 & 12 & 105 & 7 & 1 & $14.666,67$ & $9.100,00$ & $5.566,67$ \\
\hline
\end{tabular}




\begin{tabular}{|c|c|c|c|c|c|c|c|c|c|c|c|c|c|}
\hline 氞 & GRUPO DE MATERIAIS & ANO & $\begin{array}{l}\text { PE } \\
\text { ou } \\
\text { SRP }\end{array}$ & 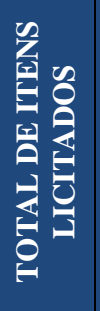 & 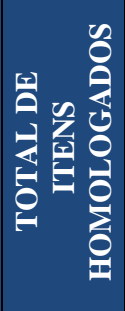 & 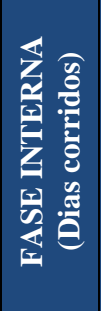 & 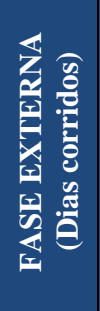 & 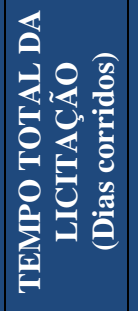 & 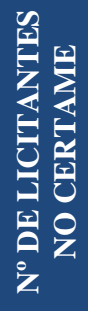 & 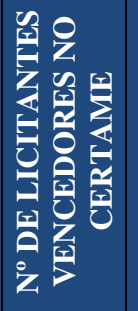 & $\begin{array}{l}\text { VLR. INICIAL } \\
\text { ESTIMADO }\end{array}$ & $\begin{array}{l}\text { VLR. TOTAL } \\
\text { HOMOLO- } \\
\text { GADO }\end{array}$ & $\begin{array}{l}\text { DIFERENÇA } \\
\text { ECONÔMICA } \\
\text { GERADA }\end{array}$ \\
\hline 97 & $\begin{array}{c}\text { Produção de material gráfico, conversão e } \\
\text { desenvolvimento de aplicativos e } \\
\text { gerenciamento de acervo para a FUB }\end{array}$ & 2012 & SRP & 87 & 87 & 163 & 94 & 257 & 12 & 2 & $19.329 .811,00$ & $11.231 .108,39$ & $8.098 .702,61$ \\
\hline \multirow[t]{2}{*}{105} & $\begin{array}{c}\text { Produção editorial (revisão da língua } \\
\text { portuguesa: tratamento de imagem; revisão da } \\
\text { normalização bibliográfica; diagramação; arte } \\
\text { da capa e projeto gráfico do miolo; } \\
\text { elaboração de ficha catalográfica; pesquisa; } \\
\text { indexação; catalogação e ISBN; formatação } \\
\text { de arquivo para livro eletrônico em formato e- } \\
\text { PDF e impressão) }\end{array}$ & 2012 & $\mathrm{PE}$ & 3 & 3 & 278 & 21 & 299 & 10 & 1 & $70.380,00$ & $42.200,00$ & $28.180,00$ \\
\hline & $\begin{array}{c}\text { SERVIÇOS DE DESCARTE E COLETA } \\
\text { DE RESIDUOS }\end{array}$ & & & & & & & & & & & & \\
\hline 002 & $\begin{array}{l}\text { Contratação de empresa especializada em } \\
\text { coleta, transporte, tratamento e disposição } \\
\text { final de resíduos químicos }\end{array}$ & 2011 & SRP & 1 & 1 & 237 & 98 & 335 & 3 & 1 & $95.000,00$ & $136.800,00$ & ${ }^{+} 41.800,00$ \\
\hline \multirow[t]{2}{*}{013} & $\begin{array}{l}\text { Contratação de empresa especializada em } \\
\text { coleta, transporte, tratamento e disposição } \\
\text { final de resíduos químicos }\end{array}$ & 2012 & $\mathrm{PE}$ & 1 & 1 & 280 & 24 & 304 & 2 & 1 & $158.800,00$ & $48.000,00$ & $110.800,00$ \\
\hline & MANUTENÇÃO AUTOMOTIVA & & & & & & & & & & & & \\
\hline 402 & $\begin{array}{l}\text { Aquisição de combustíveis e lubrificantes } \\
\text { para os veículos da FUB. }\end{array}$ & 2011 & PE & 8 & 8 & 34 & 2 & 36 & 13 & 2 & 4.261.212,00 & 4.124.608,99 & $136.603,01$ \\
\hline 060 & Gasolina, álcool e óleo diesel & 2012 & $\mathrm{PE}$ & 3 & 3 & 111 & 15 & 126 & 1 & 1 & $3.197 .598,62$ & $2.835 .696,00$ & $361.902,62$ \\
\hline & $\begin{array}{c}\text { MATERIAL DE CONSUMO PARA } \\
\text { ACONDICIONAMENTO DE RESÍDUOS } \\
\text { EM GERAL } \\
\end{array}$ & & & & & & & & & & & & \\
\hline
\end{tabular}




\begin{tabular}{|c|c|c|c|c|c|c|c|c|c|c|c|c|c|}
\hline 离 & GRUPO DE MATERIAIS & ANO & $\begin{array}{l}\text { PE } \\
\text { ou } \\
\text { SRP }\end{array}$ & 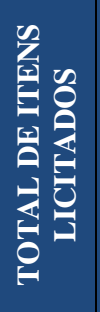 & 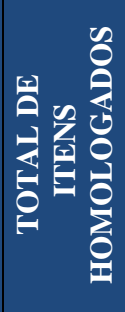 & 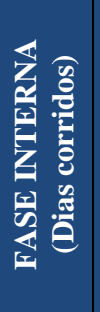 & 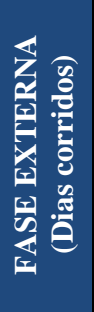 & 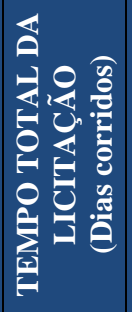 & 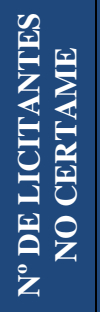 & 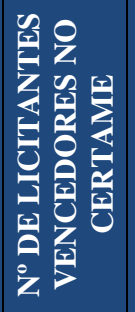 & $\begin{array}{l}\text { VLR. INICIAL } \\
\text { ESTIMADO }\end{array}$ & $\begin{array}{l}\text { VLR. TOTAL } \\
\text { HOMOLO- } \\
\text { GADO }\end{array}$ & $\begin{array}{l}\text { DIFERENÇA } \\
\text { ECONÔMICA } \\
\text { GERADA }\end{array}$ \\
\hline 403 & Containers e lixeiras & 2011 & $\mathrm{PE}$ & 2 & 2 & 112 & 26 & 138 & 42 & 2 & $250.500,00$ & $118.195,00$ & $132.305,00$ \\
\hline \multicolumn{14}{|c|}{$\begin{array}{l}\text { AQUISIÇÃO/LOCAÇÃO DE VEÍCULOS, } \\
\text { MÁQUINAS E EQUIPAMIENTOS }\end{array}$} \\
\hline 023 & Locação de ônibus & 2012 & $\mathrm{PE}$ & 10 & 10 & 292 & 51 & 343 & 21 & 02 & $5.000 .000,00$ & $4.954 .800,00$ & $45.200,00$ \\
\hline \multicolumn{14}{|c|}{$\begin{array}{c}\text { SERVIÇOS DE TELECONFERÊNCIA E } \\
\text { VÍDEO-AULAS }\end{array}$} \\
\hline 011 & $\begin{array}{l}\text { Contratação de empresa especializada em } \\
\text { planejamento, organização, execução e } \\
\text { realização de teleconferência interativa, com } \\
\text { inclusão de produção de recursos de vídeo e } \\
\text { audiovisuais, telefonia } 0800 \text {, criação de arte, } \\
\text { estúdio, cenário e equipe técnica }\end{array}$ & 2011 & $\mathrm{PE}$ & 1 & 1 & 46 & 10 & 56 & 9 & 1 & $286.966,67$ & $100.050,00$ & $186.916,67$ \\
\hline 084 & Serviços de teleconferência interativa & 2012 & $\mathrm{PE}$ & 1 & 1 & 75 & 119 & 194 & 1 & 1 & $234.700,00$ & $195.000,00$ & $39.700,00$ \\
\hline 078 & $\begin{array}{l}\text { Serviço especializado na produção de vídeo- } \\
\text { aulas }\end{array}$ & 2012 & $\mathrm{PE}$ & 1 & 1 & 101 & 106 & 207 & 22 & 1 & $89.926,67$ & $21.800,00$ & $68.126,67$ \\
\hline \multicolumn{14}{|c|}{$\begin{array}{l}\text { SERVIÇOS DIVERSOS DE PESSOA } \\
\text { JURÍDICA }\end{array}$} \\
\hline 004 & $\begin{array}{l}\text { Manutenção e aquisição de peças para o } \\
\text { reparo da caldeira do RU }\end{array}$ & 2011 & $\mathrm{PE}$ & 1 & 1 & 59 & 18 & 77 & 10 & 1 & $85.870,00$ & $50.500,00$ & $35.370,00$ \\
\hline
\end{tabular}


Serviços de limpeza, conservação, garagista, portaria, zeladoria, jardinagem, dedetização,

desinfecção de caixa d'água e manutenção

$$
\text { elétrica }
$$

Serviços de instalação e montagem de quatro

033 centrais e quatro postos de consumo para rede

$$
\text { de gases especiais }
$$

Locação de 2.000 cadeiras para as colações de grau da UnB

040 Instalação e montagem de equipamentos de caldeiraria

읍

PE

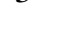

窟

文

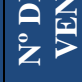

更

GERAIDA

067 Contratação de empresa especializada em

$$
\text { levantamento de geofísica }
$$

Contratação de empresa especializada para

071 fornecimento e instalação de equipamentos de sonorização e imagem

Serviços de fornecimento, retirada e

074 instalação de 04 elevadores automáticos tipo monta carga para a cozinha central do RU 


\begin{tabular}{|c|c|c|c|c|c|c|c|c|c|c|c|c|c|}
\hline 疍 & GRUPO DE MATERIAIS & ANO & $\begin{array}{l}\text { PE } \\
\text { ou } \\
\text { SRP }\end{array}$ & 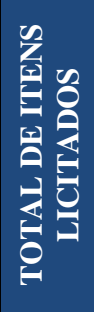 & 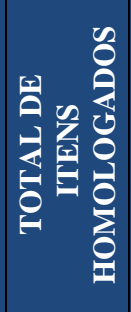 & 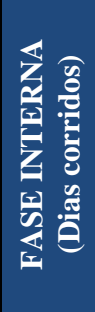 & 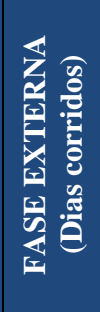 & 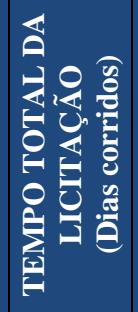 & 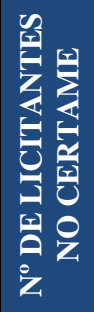 & 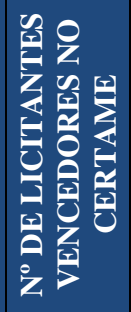 & $\begin{array}{l}\text { VLR. INICIAL } \\
\text { ESTIMADO }\end{array}$ & $\begin{array}{l}\text { VLR. TOTAL } \\
\text { HOMOLO- } \\
\text { GADO }\end{array}$ & $\begin{array}{l}\text { DIFERENÇA } \\
\text { ECONÔMICA } \\
\text { GERADA }\end{array}$ \\
\hline 075 & $\begin{array}{c}\text { Fornecimento e instalação de circuito fechado } \\
\text { de TV }\end{array}$ & 2011 & $\mathrm{PE}$ & 1 & 1 & 57 & 6 & 63 & 10 & 1 & $30.587,86$ & $18.000,00$ & $12.587,86$ \\
\hline 077 & $\begin{array}{l}\text { Serviços especializados na área de TI, } \\
\text { visando a aquisição de solução de hardware } \\
\text { e/ou software, manutenção, suporte técnico e } \\
\text { atualização para proteção AntiSpam para } \\
\text { servidores de correio eletrônico }\end{array}$ & 2011 & $\mathrm{PE}$ & 1 & 1 & 168 & 12 & 180 & 12 & 1 & $149.800,00$ & $133.200,00$ & $16.600,00$ \\
\hline 089 & $\begin{array}{c}\text { Serviços de instalação, manutenção e suporte } \\
\text { de link de comunicação de dados, para a } \\
\text { interligação do campus Darcy Ribeiro aos } \\
\text { campi da FCE, FGA e Núcleo de Prática } \\
\text { Jurídica em Ceilândia }\end{array}$ & 2011 & PE & 1 & 1 & 70 & 104 & 174 & 6 & 1 & $1.185 .727,30$ & $789.950,00$ & $395.777,30$ \\
\hline 098 & $\begin{array}{c}\text { Contratação de seguro automobilístico com } \\
\text { assistência } 24 \text { horas, para o período de } 12 \\
\text { meses, para } 1 \text { micro-ônibus e } 4 \text { ônibus da } \\
\text { frota da FUB }\end{array}$ & 2011 & $\mathrm{PE}$ & 1 & 1 & 76 & 28 & 104 & 1 & 1 & $78.584,96$ & $50.000,00$ & $28.584,96$ \\
\hline 006 & $\begin{array}{c}\text { Serviços de elaboração do plano de } \\
\text { gerenciamento de resíduos sólidos e perigosos } \\
\text { da FUB }\end{array}$ & 2012 & SRP & 1 & 1 & 195 & 147 & 342 & 8 & 1 & $546.733,55$ & $55.000,00$ & $491.733,55$ \\
\hline 015 & $\begin{array}{c}\text { Manutenção, teste hidrostático e recarga de } \\
\text { extintores de incêndio }\end{array}$ & 2012 & $\mathrm{PE}$ & 8 & 8 & 223 & 42 & 265 & 8 & 2 & $146.977,14$ & $138.037,50$ & $8.939,64$ \\
\hline 021 & $\begin{array}{c}\text { Prestação de serviços de terceirização para o } \\
\text { RU }\end{array}$ & 2012 & PE & 1 & 1 & 64 & 35 & 99 & 12 & 1 & $4.857 .545,57$ & $3.999 .999,99$ & $857.545,58$ \\
\hline
\end{tabular}




\begin{tabular}{|c|c|c|c|c|c|c|c|c|c|c|c|c|c|}
\hline 悬 & GRUPO DE MATERIAIS & ANO & $\begin{array}{l}\text { PE } \\
\text { ou } \\
\text { SRP }\end{array}$ & 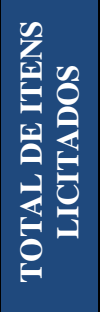 & 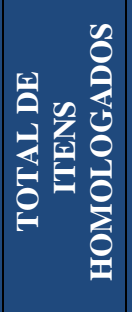 & 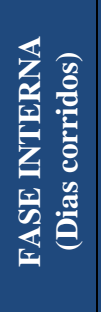 & 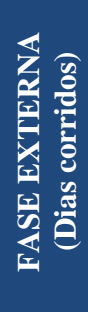 & 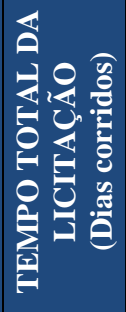 & 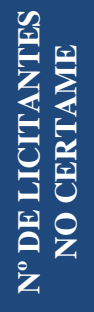 & 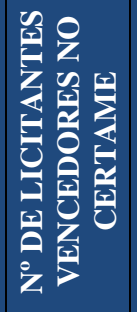 & $\begin{array}{l}\text { VLR. INICIAL } \\
\text { ESTIMADO }\end{array}$ & $\begin{array}{l}\text { VLR. TOTAL } \\
\text { HOMOLO- } \\
\text { GADO }\end{array}$ & $\begin{array}{l}\text { DIFERENÇA } \\
\text { ECONÔMICA } \\
\text { GERADA }\end{array}$ \\
\hline 032 & Confecção de camisetas & 2012 & PE & 7 & 7 & 128 & 274 & 402 & 36 & 3 & $100.261,33$ & $25.308,00$ & $74.952,53$ \\
\hline 046 & $\begin{array}{l}\text { Confecção, instalação e revitalização de } \\
\text { totens de identificação nos campi da UnB }\end{array}$ & 2012 & PE & 2 & 2 & 167 & 16 & 183 & 8 & 1 & $93.600,00$ & $79.200,00$ & $14.400,00$ \\
\hline 062 & Contratação de serviços de garçom & 2012 & $\mathrm{PE}$ & 1 & 1 & 211 & 34 & 245 & 30 & 1 & $180.950,70$ & $142.899,84$ & $38.050,86$ \\
\hline 082 & Contratação de serviços de arbitragem & 2012 & SRP & 8 & 6 & 90 & 138 & 228 & 8 & 1 & $324.600,00$ & $153.133,90$ & $171.466,10$ \\
\hline 088 & $\begin{array}{c}\text { Parecer técnico do perfil sócio econômico da } \\
\text { população da RIDE-DF, por meio de } \\
\text { georeferenciamento de setores censitários e } \\
\text { visita in loco }\end{array}$ & 2012 & SRP & 1 & 1 & 78 & 13 & 91 & 4 & 1 & $20.460 .000,00$ & $19.000 .000,00$ & $1.460 .000,00$ \\
\hline 100 & $\begin{array}{l}\text { Serviço de plotagem de cópias de projetos e } \\
\text { documentos de arquitetura e engenharia }\end{array}$ & 2012 & SRP & 3 & 3 & 487 & 25 & 512 & 4 & 1 & $9.451,00$ & $3.212,00$ & $6.239,00$ \\
\hline 112 & $\begin{array}{l}\text { Serviços de produção fotográfica das } \\
\text { edificações projetadas pelo CEPLAN e } \\
\text { pesquisa iconográfica para publicação }\end{array}$ & 2012 & PE & 1 & 1 & 328 & 31 & 359 & 4 & 1 & $8.166,67$ & $7.700,00$ & 466,67 \\
\hline
\end{tabular}

Fonte: Portal de Compras Eletrônicas do Governo Federal - COMPRASNET

Diretoria de Compras da UnB 